Raquel Cecília Goy Girardi

\title{
COMPORTAMENTO DE MATRIZES DE COLÁGENO UTILIZADAS NO TRATAMENTO DE FERIDAS PLANAS INDUZIDAS EM PELE DE RATO
}

Dissertação apresentada ao Programa de PósGraduação Interunidades em Bioengenharia, Escola de Engenharia de São Carlos, Faculdade de Medicina de Ribeirão Preto e Instituto de Química de São Carlos da Universidade de São Paulo, para a obtenção do Título de Mestre em Bioengenharia.

Orientadora: Prof $^{\mathrm{a}}$. $\mathrm{Dr}^{\mathrm{a}}$. Ana Maria de Guzzi Plepis

São Carlos

2005 
Dedico este trabalho primeiramente ao Paulo, meu marido, idealizador desta conquista que, mesmo ciente das dificuldades e ausências que viriam, teve altruísmo suficiente para me estimular e amparar durante todo tempo. Segundo, às minhas filhas, Fernanda e Julia, por se resignarem amorosamente a tantos "nãos" inevitáveis para que eu pudesse manter a disciplina e a concentração no trabalho. Por último, à minha mãe, D. Odette, professora por toda uma vida, em quem me espelho moralmente. 


\section{AGRADECIMENTOS}

Agradeço à Ana, orientadora deste trabalho, por ter me acolhido como aluna e me oferecido todas as condições necessárias para que eu realizasse sempre o melhor.

Obrigada à CAPES, que financiou parte desta pesquisa.

Sou grata aos funcionários do Laboratório de Biomateriais do Departamento de Química da USP/São Carlos, por gentilmente cederem o material para este estudo.

Agradeço ao Nelson, funcionário da Bioengenharia, que tornou possível meu contato amigável e seguro com os ratos.

À Prof ${ }^{\mathrm{a}}$. Dr ${ }^{\mathrm{a}}$. Nelcy Senerich Verani, responsável pelo Laboratório de Histologia do Departamento de Hidrobiologia da UFSCAR, por ceder toda estrutura necessária à preparação do material para histologia; e à $\mathrm{D}$. Amábile por ter me instruído e acompanhado em cada passo.

Ao amigo Mário Cunha Pereira Leite e Paulo César Maiorka, pela paciência e horas dedicadas à leitura das lâminas.

Obrigada à minha irmã Rejane, pelo apoio e por me familiarizar com os recursos do computador; ao Prof. Dr. José Carlos Pereira, à Janete, à Virgínia e a todos que, mesmo não citados, contribuíram direta ou indiretamente para a realização deste trabalho. 
"Feliz aquele que transfere o que sabe e aprende o que ensina" Cora Coralina 


\section{RESUMO}

GIRARDI, R.C.G. (2005). Comportamento de matrizes de colágeno utilizadas no tratamento de feridas planas induzidas em pele de rato. Dissertação (Mestrado) Escola de Engenharia de São Carlos, Universidade de São Paulo, São Carlos, 2005.

A potencialidade do uso de uma matriz de colágeno e de um creme preparado pela mistura de um creme hidratante comercial com um gel de colágeno $(90: 10 \mathrm{~m} / \mathrm{m})$ foi avaliada no processo de cicatrização de feridas planas produzidas em pele de ratos. A matriz acelular de colágeno e o gel de colágeno foram obtidos a partir de serosa porcina por meio de um tratamento alcalino que não altera a estrutura do colágeno nativo e remove componentes celulares. Este estudo fez um comparativo macroscópico e histológico do processo cicatricial das feridas planas tratadas com soro fisiológico ou creme comercial (controles) e as tratadas com a sutura de uma membrana de colágeno (matriz) ou creme com colágeno. As feridas foram produzidas pela retirada de um flap de pele de $20 \mathrm{~mm}^{2}$ e receberam curativos diários. O material para histologia foi coletado nos $3^{\circ}, 5^{\circ}, 7^{\circ}$ e $9^{\circ}$ dias pós-cirurgia. Apesar de não ter havido uma acentuada diferença na cicatrização das feridas planas dos dois grupos de controle e no grupo que recebeu tratamento do creme contendo colágeno, a presença deste no creme indicou uma pequena diferença no grau de colageinização, o que demonstra serem válidas mais investigações nesta direção, buscando uma melhor proporção creme:gel e/ou diferentes concentrações para o gel de colágeno. A membrana demonstrou ser uma ótima opção para o reparo de lesões por ser de fácil obtenção e armazenamento, ter baixo custo e ser excelente para manuseio (maleável e resistente), além de atender às principais exigências mencionadas na literatura para qualquer curativo biológico oclusivo.

Palavras-chave: colágeno, cicatrização, pele, serosa porcina. 


\section{ABSTRACT}

GIRARDI, R.C.G. (2005). Collagen efficiency in treatment of skin rat wounds. Dissertação (Mestrado) - Escola de Engenharia de São Carlos, Universidade de São Paulo, São Carlos, 2005.

The potentiality of the use of a collagen based matrix and of a cream prepared by the mixture of a commercial cream plus collagen (90:10 w/w) were evaluated in the healing process of rats' skin. The acellular collagen matrix and the collagen gel were obtained by an alkaline treatment of porcine serosa which does not damage the native collagen structure and removes cellular components. This study compared by macroscopy analysis and histology the skin healing repair of wounds treated with physiological solution or commercial cream (control groups) and those treated with collagen based matrix suture or commercial cream plus collagen mix. The wounds were made by removing a skin flap with $20 \mathrm{~mm}^{2}$ and have received treatment every day. The material for histology was retired on the $3^{\text {rd }}, 5^{\text {th }}, 7^{\text {th }}$ and $9^{\text {th }}$ days after surgery. Even without an accentuated difference in the healing process of both control groups and the wounds treated with de commercial cream plus collagen, its presence in the cream showed a small difference of the collagen level in the new skin what validate more investigations on this way, searching better cream:gel proportion and/or different gel concentration. The matrix demonstrated to be a very good option to help wound healing because it is easily shelf able and obtainable, it has cheap cost and it is extremely nice to handle (resistant and manipulation able), besides to follow the main requirements present in the literature citation for any biologic occlusive dressing.

Keywords: collagen, wound healing, skin, porcine serosa. 


\section{ÍNDICE DE FIGURAS}

FIGURA 1 - FIGURA DE PELE EM CORTE TRIDIMENSIONAL.(ESTAÇÃO, 2005)------------ 15

FIGURA 2 - CORTE HISTOLÓGICO DA PELE (CORADO EM HE). (NCSI, 2005)------------- 15

FIGURA 3 - FILME DE POLIURETANO SOBRE ÚLCERA DE PRESSÃO ESTÁGIO I (BLANES, 2004). 25

FIGURA 4 - PLACA DE HIDROCOLÓIDE SOBRE ÚLCERA POR PRESSÃO ESTÁGIO ॥ SACRAL (BLANES, 2004). 27

FIGURA 5 - HIDROGEL EM ÚLCERA ISQUÊMICA DE MEMBRO INFERIOR (BLANES, 2004).

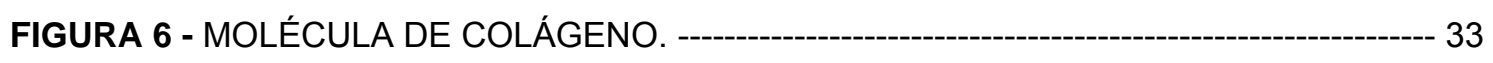

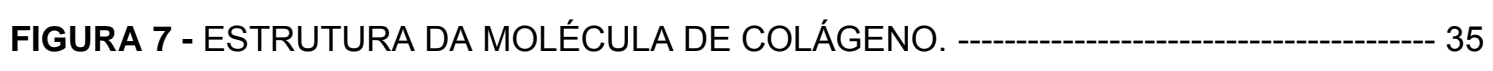

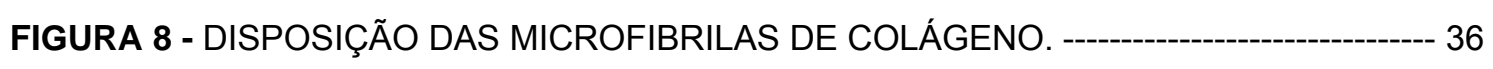

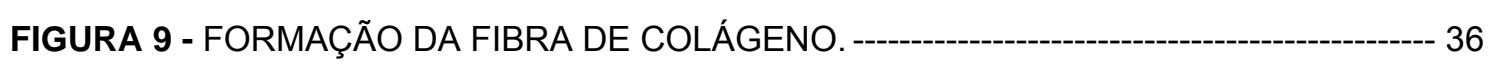

FIGURA 10 - ESQUEMA DA HIDRÓLISE DOS RESÍDUOS DE GLUTAMINA EM MEIO BÁSICO. 38

FIGURA 11 - ASPECTO MACROSCÓPICO DA SIS DESIDRATADA (À ESQUERDA) E APÓS HIDRATAÇÃO (À DIREITA) (BADYLAK, 1999). 42

FIGURA 12 - FOTOS DIGITAIS DA MARCAÇÃO (SUPERIOR), EXCISÃO DO "FLAP" (CENTRO) E ASPECTO DA FERIDA PLANA (ABAIXO). 52

FIGURA 13 - TÉCNICA HISTOLÓGICA PARA PREPARAÇÃO DE LÂMINAS (VASCONCELOS, 2005). 54

FIGURA 14 - MÓDULO ELÁSTICO E VISCOSO EM FUNÇÃO DA DEFORMAÇÃO PARA MISTURA CREME UNIVERSAL: COLÁGENO (90:10). - G'; G".---------- 64

FIGURA 15 - MÓDULO ELÁSTICO E VISCOSO EM FUNÇÃO DA FREQÜÊNCIA ANGULAR PARA MISTURA CREME UNIVERSAL-COLÁGENO (90:10). - G'; G”.----- 64 FIGURA 16 - VISCOSIDADE EM FUNÇÃO DA TAXA DE CISALHAMENTO PARA MISTURA DE CREME:COLÁGENO 65 
FIGURA 17 - MATRIZ COLAGÊNICA ANTES DO TRATAMENTO ALCALINO DE 24 HORAS.

FIGURA 18 - MATRIZ COLAGÊNICA DEPOIS DO TRATAMENTO ALCALINO DE 24 HORAS.

FIGURA 19 - (A): CURVA DSC PARA MATRIZ COLAGÊNICA DERIVADA DE SEROSA HIDRATADA OBTIDA EM N ${ }_{2}, 10^{\circ} \mathrm{C} \cdot \mathrm{MIN}^{-1}$; (B): ESCALA EXPANDIDA. 69

FIGURA 20 - ESPECTRO NA REGIÃO DO INFRAVERMELHO PARA COLÁGENO TIPO I OBTIDO POR SOLUBILIZAÇÃO DE SEROSA PORCINA.

FIGURA 21 - ESPECTRO NA REGIÃO DO INFRAVERMELHO PARA MATRIZ COLAGÊNICA UTILIZADA.

FIGURA 22 - MEV DA SUPERFÍCIE DA MATRIZ COLAGÊNICA COM AUMENTO DE 300X. 73 FIGURA 23 - MEV DA SUPERFÍCIE DA MATRIZ COLAGÊNICA COM AUMENTO DE 3500X.

FIGURA 24 - ASPECTO DA FERIDA APÓS RECEBER TRATAMENTO COM O CREME.---- 74 FIGURA 25 - POSICIONAMENTO DA MEMBRANA (ACIMA), SUA SUTURA (CENTRO) E SEU ASPECTO IMEDIATAMENTE APÓS FIXAÇÃO (ABAIXO). 75

FIGURA 26 - TERCEIRO DIA: SORO (ESQ.), MERCK® (CENTRO) E CREME-COLÁGENO (DIR.). 77

FIGURA 27 - TERCEIRO DIA: ASPECTO DA MEMBRANA. 77

FIGURA 28 - QUINTO DIA: TAMANHO E ASPECTO DO TECIDO DE GRANULAÇÃO NAS FERIDAS TRATADAS COM SORO (ESQ.), MERCK® (CENTRO) E CREMECOLÁGENO (DIR.). 78

FIGURA 29 - QUINTO DIA: TAMANHO E ASPECTO DAS FERIDAS COM MEMBRANAS.-- 79 FIGURA 30 - SÉTIMO DIA: ASPECTO DAS FERIDAS TRATADAS COM SORO (ESQ.),

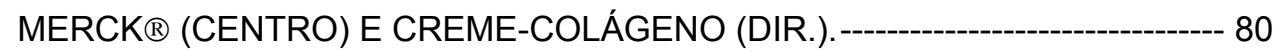

FIGURA 31 - SÉTIMO DIA: ASPECTO DAS FERIDAS COM MEMBRANAS. 80 FIGURA 32 - NONO DIA: ASPECTO DA FERIDA TRATADA COM SORO FISIOLÓGICO. --- 81 FIGURA 33 - NONO DIA: ASPECTO DA FERIDA TRATADA COM MERCK®. 82 FIGURA 34 - NONO DIA: ASPECTO DA FERIDA TRATADA COM CREME COM COLÁGENO. 
FIGURA 35 - NONO DIA: ASPECTO DA FERIDA TRATADA COM SUTURA DA MEMBRANA.

FIGURA 36 - CORTE HISTOLÓGICO DE PELE TRATADA COM SORO FISIOLÓGICO (7 DIAS/MALLORY) - AUMENTO DE 40X).

FIGURA 37 - CORTE HISTOLÓGICO DE PELE TRATADA COM SORO FISIOLÓGICO (7 DIAS/MALLORY) - AUMENTO DE 200X.

FIGURA 38 - CORTE HISTOLÓGICO DE PELE TRATADA COM SORO FISIOLÓGICO (7DIAS/HE) - AUMENTO DE 40X.

FIGURA 39 - CORTE HISTOLÓGICO DE PELE TRATADA COM MERCK ${ }^{\circledR}$ (3DIAS/HE) AUMENTO DE 40X. 86

FIGURA 40 - CORTE HISTOLÓGICO DE PELE TRATADA COM CREME COM COLÁGENO (7DIAS/MALLORY) - AUMENTO DE 40X.

FIGURA 41 - CORTE HISTOLÓGICO DE PELE TRATADA COM CREME COM COLÁGENO (7DIAS/MALLORY) - AUMENTO DE 200X. 88

FIGURA 42 - CORTE HISTOLÓGICO DE PELE TRATADA COM CREME COM COLÁGENO (9 DIAS/MALLORY) - AUMENTO DE 40X. 88

FIGURA 43 - CORTE HISTOLÓGICO DE PELE TRATADA COM CREME COM COLÁGENO (9 DIAS/MALLORY) - AUMENTO DE 200X. 89

FIGURA 44 - CORTE HISTOLÓGICO DE PELE TRATADA COM CREME COM COLÁGENO (9 DIAS/HE) - AUMENTO DE 40X. 89

FIGURA 45 - CORTE HISTOLÓGICO DE PELE TRATADA COM SUTURA DA MEMBRANA (7 DIAS/HE) - AUMENTO DE 200X. 90

FIGURA 46 - CORTE HISTOLÓGICO DE PELE TRATADA COM SUTURA DA MEMBRANA (7 DIAS/MALLORY) - AUMENTO DE 200X. 91 FIGURA 47 - CORTE HISTOLÓGICO DE PELE TRATADA COM MEMBRANA (7 DIAS/HE) AUMENTO DE 40X. 91 


\section{ÍNDICE DE TABELAS}

TABELA 1 - PREPARAÇÃO DO TRICRÔMIO DE MALLORY. $-61$

TABELA 2 - PARÂMETROS VISCOELÁSTICOS PARA MISTURA CREME:COLÁGENO.-----66 TABELA 3 - RESUMO DOS RESULTADOS HISTOLÓGICOS. $-93$ 


\section{SUMÁRIO}

I - INTRODUÇÃO---

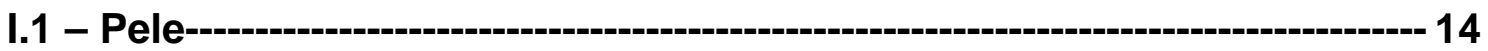

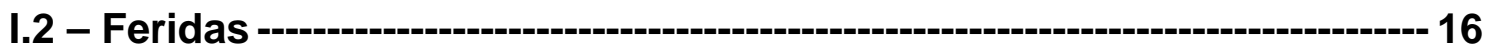

I.3 -Processo de reparação tissular ---:- 17

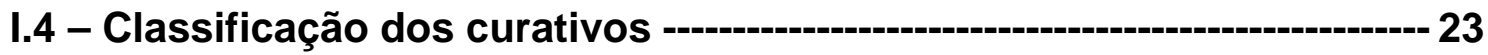

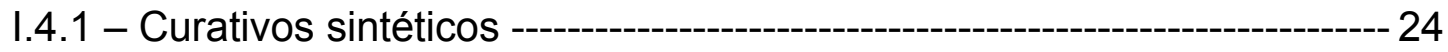

I.4.1.1 - Convencionais -

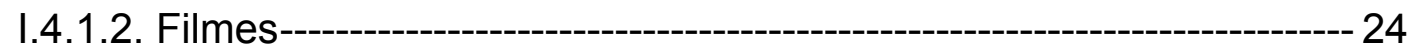

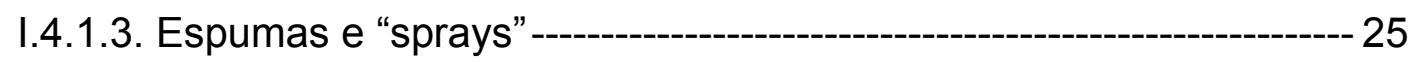

I.4.1.4. Curativos compostos-- 26

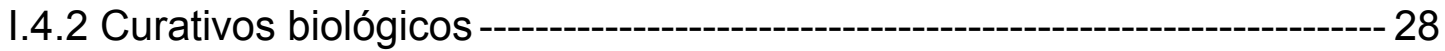

I.5 - Materiais atualmente usados e propostos para reposição de pele--- 29

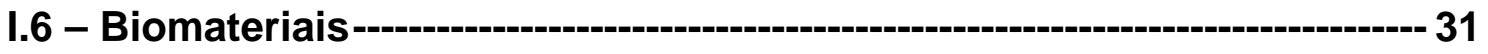

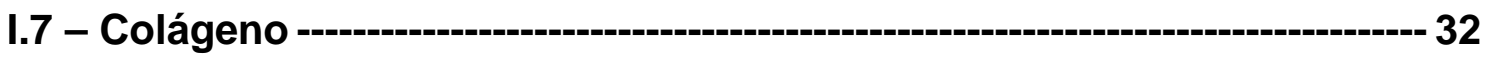

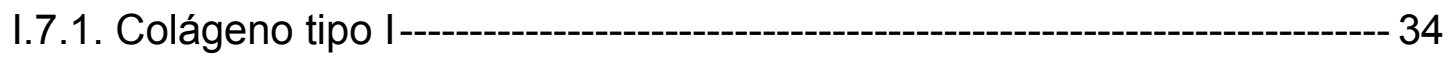

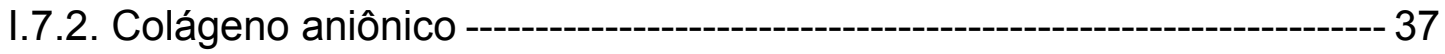

I.7.3. Curativos à base de colágeno ---_- 38

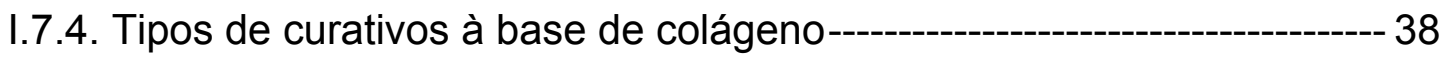

I.7.4.1. Matriz de colágeno proveniente da submucosa de intestino delgado

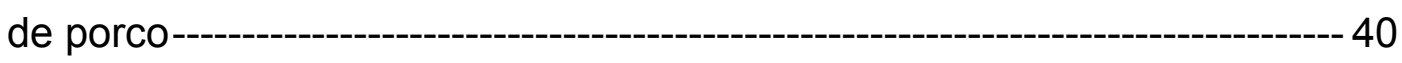

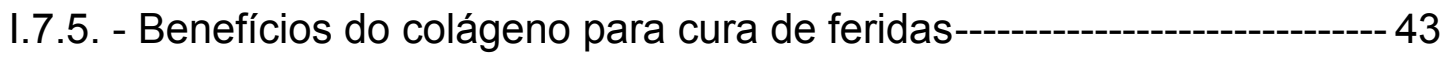

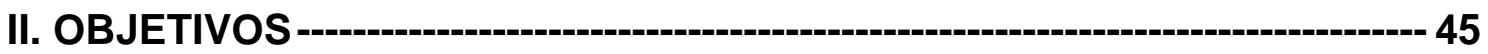

III. MATERIAIS E MÉTODOS -- 46

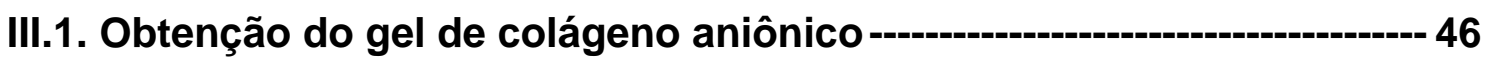


III.2. Creme ---------------------------------------------------------------------------- 46

III.2.1. Preparação do creme com colágeno --------------------------------- 47

III.2.2. Caracterização reológica do creme --- 47

III.3. Obtenção da membrana de colágeno -

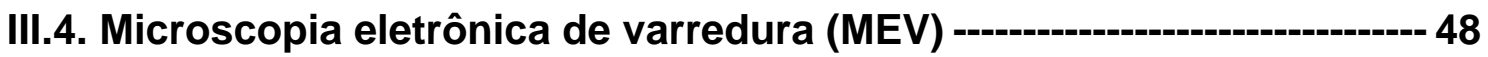

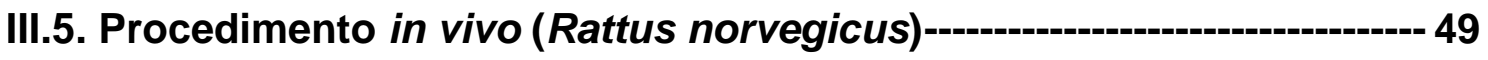

III.5.1. Piloto I -- 50

III.5.2. Piloto II -- 50

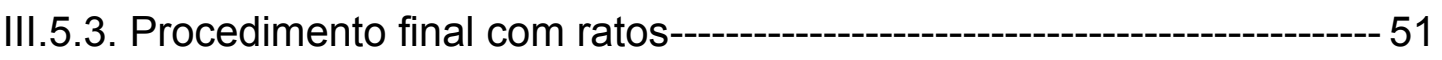

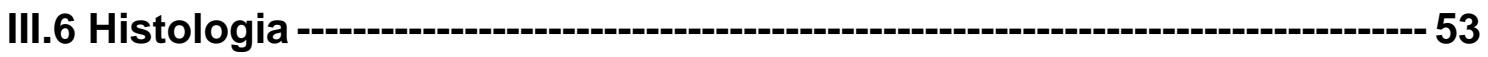

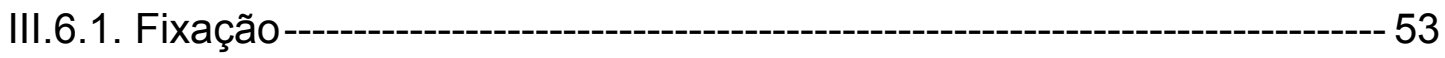

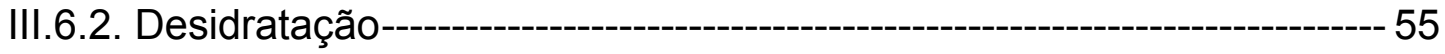

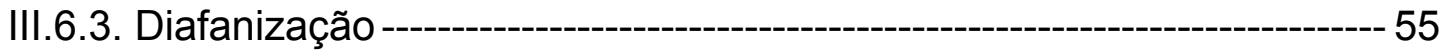

III.6.4. Inclusão --- 55

III.6.5. Microtomia e Montagem dos Cortes sobre as Lâminas--------------- 57

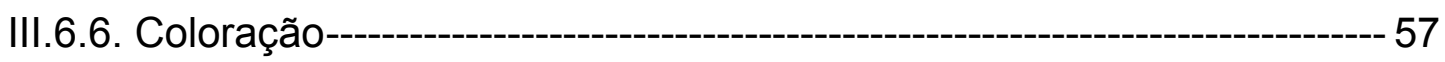

III.6.6.1. Corantes- 58

III.6.6.2. Método de Coloração com HE---------------------------------- 59

III.6.6.3. Método de coloração com Mallory (A preparação do corante está

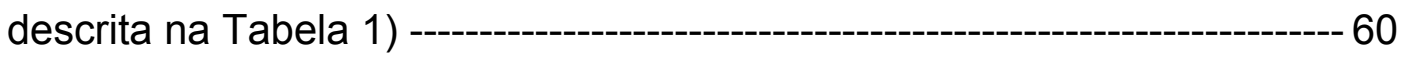

III.6.6.4. Montagem das Lâminas em Bálsamo do Canadá ------------------- 61

IV. RESULTADOS E DISCUSSÕES --:- 63

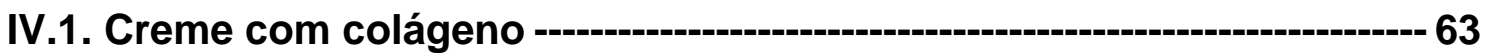

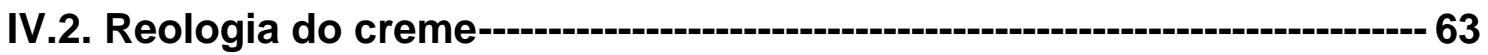

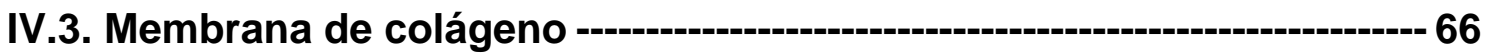

IV.3.1. Aspecto da membrana ------------ 66

IV.3.2 Caracterização da membrana (MENDES, 2003) --------------- 68

IV.3.2.1 Estabilidade Térmica ------- 68

IV.3.2.3 Espectroscopia na Região do Infravermelho ------------------------- 70 
IV.3.2.4. Microscopia Eletrônica de Varredura (MEV)------------------------- 72

IV.3.5.1. Terceiro dia----_- 76

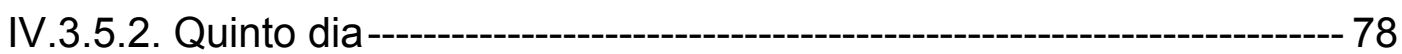

IV.3.5.3. Sétimo dia --- 79

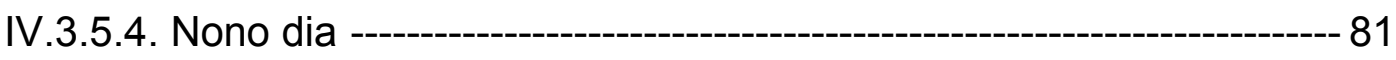

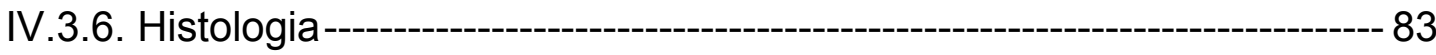

IV.3.6.1. Tratamento com solução fisiológica (controle 1)---------------- 83

IV.3.6.2. Tratamento com creme sem colágeno - Merck ${ }^{\circledR}$ (controle 2)----- 85

IV.3.6.3. Tratamento com creme contendo colágeno --------------------- 87

IV.3.6.4. Tratamento com sutura da membrana --_-_-_- 90

V - CONCLUSÕES --.-1.-- 96

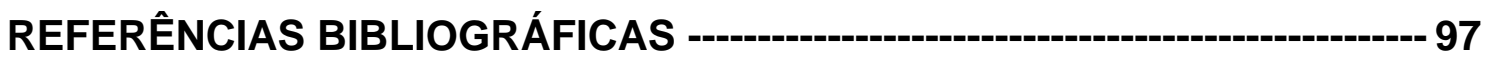




\section{I - INTRODUÇÃO}

\section{I.1 - Pele}

A pele recobre toda a superfície do corpo, sendo seu maior órgão. Tem continuidade com as membranas mucosas que revestem os sistemas digestivo, respiratório e urogenital, nos locais onde estes se abrem para a superfície. Chega a atingir $16 \%$ do peso corporal e costuma ser o órgão mais afetado nas injúrias. Apresenta múltiplas funções, entre as quais, graças à camada córnea que reveste a epiderme, proteger o organismo contra a perda de água por evaporação (dessecação) e contra o atrito. Além disso, através das suas terminações nervosas, está em comunicação constante com o ambiente. Por meio dos seus vasos, glândulas e tecido adiposo, colabora na termorregulação do corpo (JUNQUEIRA, 1990). Esta estrutura complexa (Figura 1) é composta por três camadas:

- $\quad$ Epiderme: É a camada mais externa, constituída por um epitélio estratificado pavimentoso queratinizado; sua espessura e estrutura variam com o local estudado. A epiderme está organizada em camadas e à medida que as mais superficiais são eliminadas, as camadas mais profundas são restauradas por divisão celular. Em regiões onde a pele é mais espessa, como a sola dos pés, a epiderme chega a apresentar cinco camadas: germinativa, espinhosa, granulosa, lúcida e córnea. A camada germinativa é a mais profunda e faz limite com a derme; a camada córnea é a mais superficial. Esta é constituída por células escamosas cheias de queratina (Figura 2), proporcionando proteção contra traumas físicos e químicos. As várias camadas de queratinócitos intimamente unidos uns aos outros, fornecem barreira contra a invasão de microorganismos e água. O pigmento melanina na epiderme protege os tecidos subjacentes dos efeitos nocivos da luz ultravioleta. 


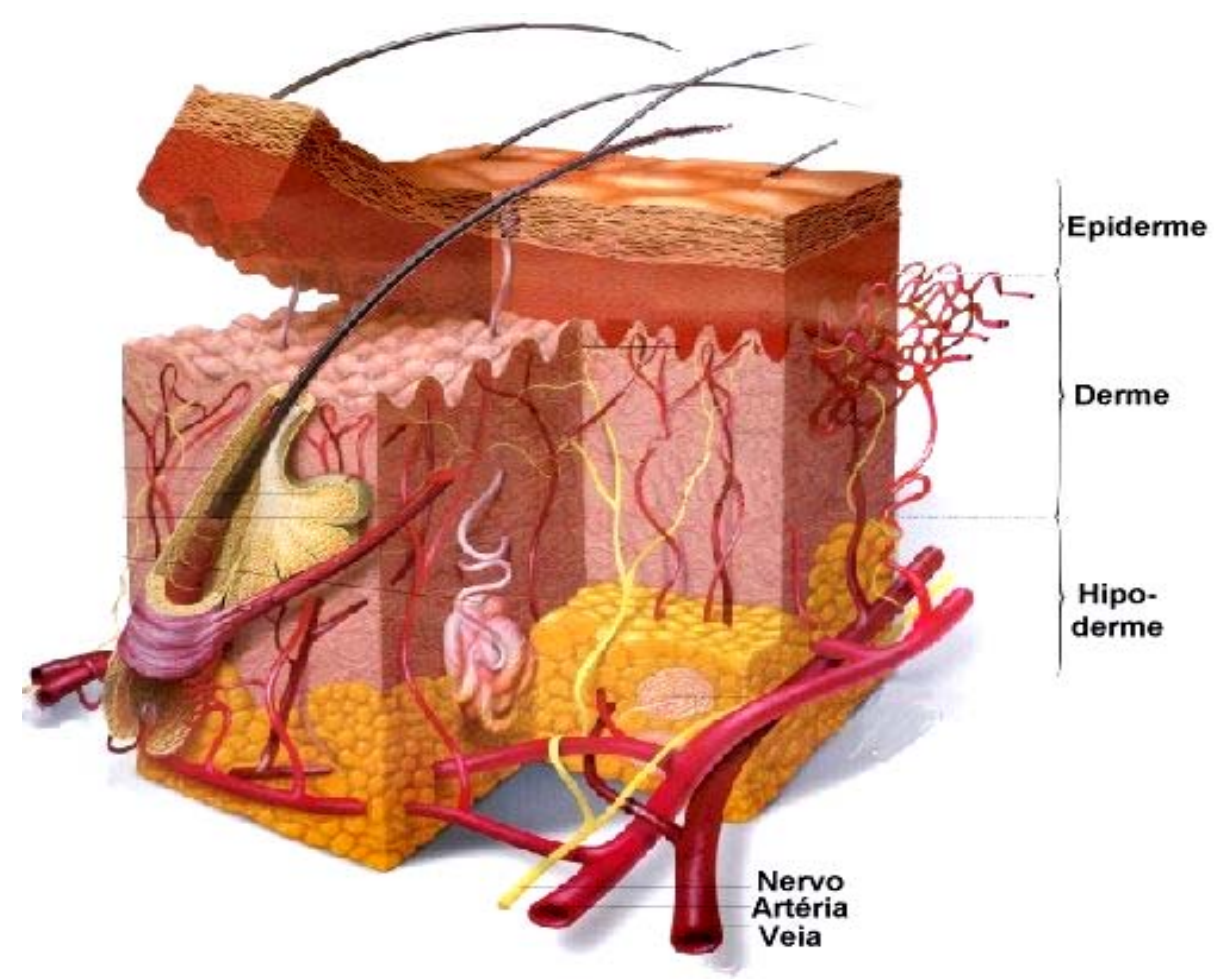

Figura 1 - Figura de pele em corte tridimensional.(ESTAÇÃO, 2005)

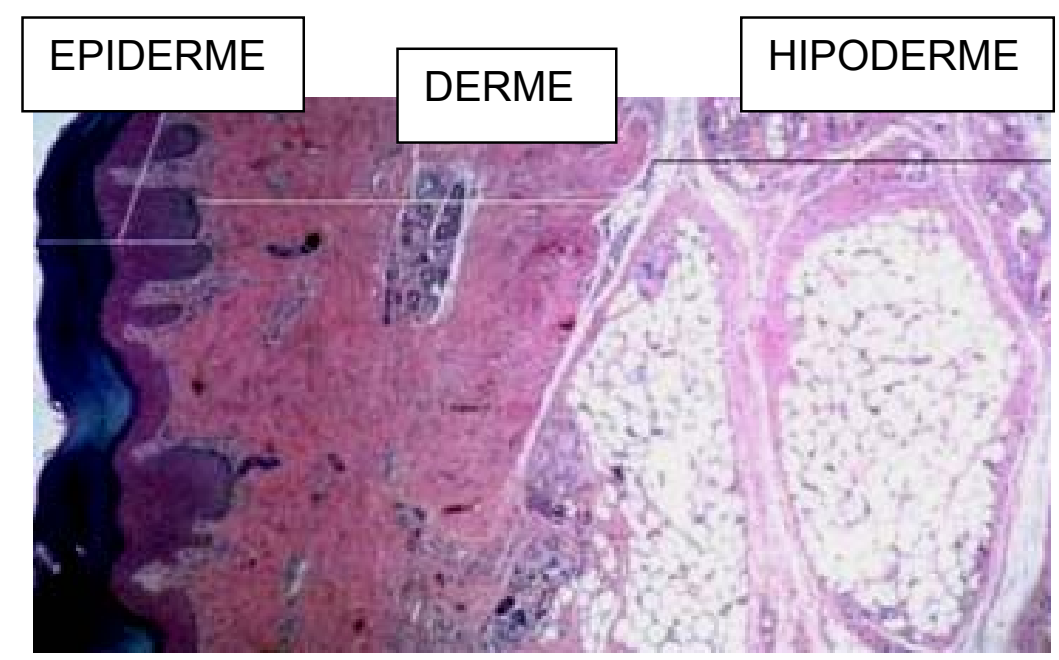

Figura 2 - Corte histológico da pele (corado em HE). (NCSI, 2005) 
- Derme: É uma camada espessa de tecido conjuntivo sobre o qual a epiderme está apoiada; sua espessura é variável de acordo com a região observada. Sua superfície externa é bastante irregular, onde são vistas saliências que acompanham as reentrâncias correspondentes da epiderme (papilas dérmicas); em seu limite inferior está o tecido subcutâneo. Nesta camada estão presentes os anexos da pele (pelos, unhas, glândulas sebáceas e sudoríparas), muitos vasos sangüíneos, vasos linfáticos, nervos e receptores especializados em determinar sensações de frio, calor, tato, pressão e dor. A derme fornece uma base firme para a epiderme e para os anexos cutâneos. As fibras colágenas proporcionam grande força de tensão e as fibras elásticas lhe dão flexibilidade.

- $\quad$ Hipoderme: É formada por tecido conjuntivo frouxo, que une de maneira pouco firme a derme aos órgãos subjacentes. É a camada responsável pelo deslizamento da pele sobre as estruturas na qual se apóia. Dependendo da região em estudo e do grau de nutrição do organismo, a hipoderme poderá ter uma camada variável de tecido adiposo que, quando desenvolvida, constitui o panículo adiposo. Como a gordura é um bom isolante térmico o panículo adiposo proporciona proteção contra o frio (JUNQUEIRA, 1990; SHERIDAN, 1999).

\section{2 - Feridas}

Uma ferida é representada pela interrupção da continuidade de um tecido corpóreo, em maior ou em menor extensão, causada por qualquer tipo de trauma físico, químico, mecânico ou desencadeada por uma afecção clínica que aciona de imediato as frentes da defesa orgânica para o reparo (ARNOLD, 1994).

As feridas podem ser classificadas segundo diversos parâmetros, que auxiliam no diagnóstico, na evolução e na definição do tipo de tratamento, tais como: 
* Quanto ao diagnóstico etiológico: define a origem da doença que propiciou o aparecimento da lesão cutânea.

* Quanto à causa: define o mecanismo de ação.

* Quanto à morfologia: descreve a localização, número, dimensão e profundidade.

* Quanto ao grau de contaminação: limpa, contaminada ou infectada.

* Quanto à fase cicatricial: define as três etapas: inflamatória, proliferativa e de maturação.

* Quanto à característica do exsudato: relata a sua presença ou ausência, aspecto, coloração e odor.

* Quanto às fístulas: indica presença, local e origem.

* Quanto à característica do leito da ferida: necrótico, fibrinoso, necrótico-fibrinoso, granulação e epitelização.

* Quanto à cultura da secreção: define o agente etiológico e a antibioticoterapia específica.

* Quanto à evolução da ferida: aguda ou crônica.

* Quanto ao tipo de cicatrização: primária, secundária ou primária tardia (ABLA, 1995).

\section{I.3 - Processo de reparação tissular}

O processo de reparação tissular compreende dois mecanismos de restauração dos tecidos: a regeneração e a cicatrização. A regeneração ocorre com a reposição tissular "original". O trauma inicial gera uma resposta inflamatória aguda que se manifesta através de edema e formação de exsudato seroso, rico em leucócitos, que cessa em torno de 72 horas. As células epidérmicas, das margens da ferida e das invaginações epidérmicas dos folículos pilosos e glândulas (sudoríparas e sebáceas) começam a proliferar e migrar sobre o leito da ferida, ocluindo sua superfície promovendo, assim, a cicatrização (ABLA, 1995; SANTOS, 2000). 
A evolução cicatricial das feridas é composta de uma série de estágios complexos, interdependentes e simultâneos, e representa o esforço do corpo para restaurar a função e a estrutura natural de um tecido injuriado. Este processo é sem dúvida uma das partes mais primordiais e vitais na existência de qualquer código genético, sendo o objetivo do mesmo restabelecer o funcionamento ideal para a sobrevivência e atividade do organismo vivo. O processo cicatricial é, em geral, uma replicação de significantes partes em crescimento e desenvolvimento, o que acaba por acontecer num ambiente um tanto quanto modificado em relação àquele no qual a formação do organismo ocorreu (WIEMAN, 1998).

As estruturas substitutas devem ser produzidas de modo que permitam à parte original ficar tão recomposta quanto possível. Nos seres vivos, o processo de reconstrução tecidual é concluído com notável sucesso, mas é improvável que o corpo tenha exatamente as mesmas "ferramentas" (matériaprima e ambiente) de antes para trabalhar, por isso existem limites no que concerne à qualidade da replicação (WIEMAN, 1998).

Desde o início da espécie humana, houve quem procurasse auxiliar o corpo na tentativa natural de restaurar suas partes injuriadas. Claramente, a prática do uso de vários tipos de curativos e cataplasmas sobre feridas para melhorar a perspectiva de cura pré-data em muito nosso conhecimento científico da fisiologia da cicatrização de ferimentos e, através dos tempos, tem sido acumulado algum conhecimento inato ou desejo de colaborar com o melhoramento do processo de cura das feridas, com a certeza de que isso aumenta as chances de sobrevivência dos indivíduos (WIEMAN, 1998).

Exemplos sofisticados de tentativas de otimizar o processo cicatricial foram encontrados em culturas da Era do Ferro, onde eram praticados transplantes dentários e, mais tarde, na Índia, China e culturas árabes, onde os curativos eram cuidadosamente prescritos, sendo praticado o transplante de partes do corpo (pele) (WIEMAN, 1998). Na literatura está descrito que, na préhistória, vários agentes como extratos de plantas, água, neve, gelo, frutas e lama eram aplicados sobre as feridas. Na Mesopotâmia, as feridas eram lavadas com água ou leite e o curativo era realizado com mel ou resina, sendo que a lã de carneiro, as folhas e cascas de árvores eram utilizadas para a cobertura das lesões. Os egípcios concluíram que uma ferida fechada 
cicatrizava mais rápido do que aberta, por isso, utilizavam tiras de pano para manter unidas as margens da lesão. Hipócrates sugeria que as feridas contusas fossem tratadas com calor e pomadas para promover a supuração, remover o material necrótico e reduzir a inflamação. No início da era cristã, Celsus preconizava o fechamento primário das feridas recentes e o debridamento das que estivessem contaminadas para posteriormente serem suturadas e, além disso, classificou os diferentes tipos de lesões de pele e deu detalhes do tratamento de cada uma delas. A introdução das armas de fogo nas guerras européias no século XIV levou ao surgimento de um novo tipo de ferida de cura mais difícil, e Ambroise Paré, na Renascença, reformulou seu tratamento. O avanço da química levou a descoberta de compostos de cloro e iodo que foram utilizados para limpeza do material e da pele nos séculos XVIII e XIX. Atualmente a pretensão é de interferir na biologia molecular, abordando a síntese de substâncias envolvidas nos fenômenos cicatriciais (ANDRADE, 1992; ABLA, 1995).

A ciência médica moderna continuou buscando melhorar a cicatrização das feridas e a compreensão mais clara do papel da infecção melhorou nossa habilidade de auxiliar em sua cura. O reconhecimento do papel da nutrição e de processos de doenças associadas permitiu a médicos e cirurgiões melhorarem o prognóstico destes ferimentos, tanto dos cirúrgicos quanto dos traumáticos, que são mais eficientemente curados quanto maior atenção é dada ao bom condicionamento geral do corpo (isto é, onde um ambiente fisiológico adequado ao processo de cura estiver disponível) (WIEMAN, 1998).

Ficou demonstrado que a reparação tecidual ocorre em três fases complexas, dinâmicas e sobrepostas, e o conhecimento destas fases evolutivas do processo fisiológico cicatricial é fundamental para o tratamento adequado da ferida, sendo divididas didaticamente em:

$\checkmark \quad$ Fase inflamatória ou exsudativa - Imediatamente após a lesão há vasoconstrição por 5 a 10 minutos, inicialmente reflexa, propiciando o fechamento dos vasos lesados. Em seguida, as células endoteliais retraem-se e perdem suas conexões, aumentando a permeabilidade vascular e permitindo a passagem dos elementos sangüíneos para a ferida; plasma, eritrócitos e leucócitos através do fenômeno de diapedese. Esta vasodilatação com 
extravasamento de elementos para o exterior do vaso forma um exsudato, e traduz-se clinicamente por tumor, calor, rubor e dor, cuja intensidade está relacionada com o tipo e grau de agressão. Juntamente com todas estas alterações, que correspondem à resposta vascular, existe a resposta de células importantes nesta fase: os neutrófilos são responsáveis pela digestão de bactérias e tecidos desvitalizados, sendo auxiliados nesta função por monócitos que transformam-se em macrófagos celulares. Após o trauma, são liberados mediadores celulares que estimulam a elaboração de substâncias, que desenvolvem o processo inflamatório (histamina, serotonina, bradicinina, prostaglandinas e tromboxanes, linfocinas, interleucina 1 e 2). $O$ fator de crescimento é liberado pelas células epidérmicas e plaquetas (BLANES, 2004).

$\checkmark \quad$ Fase proliferativa - Nesta fase, que pode durar de 12 a 14 dias, ocorre a reparação do tecido conjuntivo com formação de tecido de granulação e do epitélio. Os fibroblastos surgem por volta do segundo ou terceiro dia após o trauma. O fibrinogênio do exsudato inflamatório se transforma em fibrina, formando uma rede, onde os fibroblastos ficam aderidos, se multiplicam e começam a secretar os componentes protéicos do tecido cicatricial. Concomitante a esta fibroplasia ocorre intensa proliferação vascular. Este tecido formado por fibroblastos, substâncias produzidas por eles e vasos sangüíneos é denominado tecido de granulação, clinicamente apresentando-se sob aspecto granuloso e avermelhado. O miofibroblasto é uma célula que está presente no tecido de granulação e confere capacidade contrátil, reduzindo a área da lesão e facilitando a epitelização. A atividade mitótica do fibroblasto praticamente desaparece em torno do $15^{\circ}$ dia, quando eles passam a secretar as proteínas presentes no tecido de granulação, produzindo componentes da substância fundamental e colágeno. A substância fundamental é formada por água, eletrólitos e glicosaminoglicanas; tem aspecto semelhante a um gel e está distribuída entre fibras do tecido conjuntivo. A formação do epitélio é outro fenômeno que ocorre na fase de formação tecidual, sendo que ela acontece pelo aumento de tamanho, da divisão e da migração das células da camada basal da epiderme por sobre a área de reparação do tecido conjuntivo subjacente. Nas feridas com perda total da derme, a epitelização se faz apenas 
das margens da mesma, pois, neste caso, não há anexos cutâneos remanescentes (BLANES, 2004).

$\checkmark \quad$ Fase de maturação ou remodelação - Nesta fase ocorrem dois eventos importantes: deposição, agrupamento e remodelação do colágeno e regressão endotelial. A remodelação do colágeno inicia-se na formação do tecido de granulação e mantém-se por meses após a reepitelização. As colagenases e outras proteases produzidas por macrófagos e células epidérmicas dão direção correta às fibras colágenas difusas. Há diminuição de todos elementos celulares, inclusive fibroblastos, bem como dos elementos do tecido conjuntivo. A regressão endotelial ocorre através da diminuição progressiva de vasos neoformados e clinicamente a cicatriz se torna menos espessa, mudando de cor (BLANES, 2004). Esta etapa pode durar de meses a anos. Após a reorganização, o colágeno adquiri maior força tênsil e empalidece. A cicatriz assume a coloração semelhante à da pele adjacente (CANDIDO, 2001; ABLA, 1995).

A existência de uma variedade de tipos de feridas, com suas fases e modos variados de cicatrização, levou à evolução de diferentes tipos de curativos. Estes, antes de 1960, eram considerados apenas como produtos passivos que tinham um mínimo papel no processo de cura das lesões, porém, a pesquisa pioneira de Winter (WINTER ${ }^{1}$ apud PURNA, 2000) nos anos 60 iniciou o conceito da importância de um ambiente ideal para a cicatrização das feridas e do ativo envolvimento dos curativos para estabilizar e manter tal ambiente. Esta consciência resultou, partindo dos materiais passivos tradicionalmente conhecidos, no desenvolvimento de curativos funcionalmente ativos que, através da interação com as feridas que recobrem, criam e mantém a umidade no sítio de cicatrização.

O manejo tradicional de ferimentos envolve desinfecção, debridamento e provisão de um ambiente úmido que estimule o estabelecimento do melhor ambiente para que ocorra o processo natural de cura. Então, um curativo ideal

\footnotetext{
${ }^{1}$ WINTER, G.D. Formation of the scab and the rate of epithelialization of superficial wounds in the skin of the young domestic pig. Nature, v. 193, p. 293-294, 1962.
} 
pode ser caracterizado com base em seu desempenho, seguindo critérios que incluem:

- Provisão e manutenção de um ambiente úmido;

- Proteção da ferida contra infecções secundárias, agindo como uma barreira antibacteriana;

- Permissão de que possam ocorrer trocas gasosas adequadamente;

- Provisão de isolamento térmico, livre de partículas ou contaminantes tóxicos;

- Manejamento do excesso de exsudato, permitindo uma remoção não-traumática;

- Elasticidade e não-antigenicidade (TURNER ${ }^{2}$ apud PURNA, 2000).

Agora se sabe que há condições que devem estar presentes para que a cicatrização por primeira intenção ocorra e, dentre estas, estão a presença e justaposição dos tecidos lesados. Também é sabido que, se tais condições estiverem presentes e o ambiente for propício, a cicatrização ocorrerá em um mínimo tempo, o que poderá vir a comprometer as estrutura e função do tecido neoformado. Por outro lado, mesmo quando há extensa perda tecidual, o organismo tentará se restabelecer pela cicatrização secundária, que já provou ser mais lenta e menos eficiente do que a primária, proporcionando também homeostaticamente piores resultados para o organismo. Médicos têm conseguido converter o que seria um processo cicatricial secundário em cicatrização primária utilizando enxertos e "flaps" de pele em tempo determinado. Similarmente, tem sido possível utilizar o processo secundário para obter-se uma boa cobertura de pele em áreas consideradas de grande tensão, como nos pés, onde enxertos de pele ou transplantes iriam gerar

\footnotetext{
${ }^{2}$ TURNER, T.D. Semiocclusive and occlusive dressings. An environment for healing. The role of occlusion London UK Royal society of Medicine International Congress and Symposium. Series $\mathrm{n}^{\circ} 38,1985$.
} 
cicatrizes disfuncionais ou uma cobertura pobre que certamente falharia (WIEMAN, 1998).

Nos mamíferos, quando não é possível ocorrer regeneração celular do parênquima da pele lesionada, a continuidade anatômica é restabelecida por meio de tecido não especializado, acarretando restrição da reserva funcional deste tecido (KLEIMAN, 1987). Após a produção de uma falha cutânea a área, assim formada, sofre imediata expansão, como resultado da retração das margens da lesão, conseqüente à ação centrífuga das fibras elásticas da pele (MACGRATH, 1983).

Quando numa ferida plana inicia-se o processo de cicatrização, sua área torna-se progressivamente menor, devido ao movimento centrípeto de suas bordas, sobretudo em resposta à ação de miofibroblastos presentes no tecido de granulação (MACGRATH, 1983; ZACHARIAS, 1991). Este fenômeno é denominado de contração da ferida e sua conclusão pode requerer meses, sendo muitas vezes incompleto (FALCÃO, 2001). Em curto prazo, o fechamento de uma ferida por processo de contração de suas margens é considerado insuficiente restando ainda uma área situada dentro do perímetro correspondente, denominada de área de epitelização e, no espaço de tempo referido, a cicatrização completa-se como resultado de uma combinação dos processos de contração e epitelização (MACGRATH, 1983). A aceleração do processo de cicatrização por meio de curativos biológicos oclusivos tem sido admitida em razão desses curativos possuírem ação antibacteriana, estimularem os processos de granulação, contração e epitelização, formarem barreira física contra invasão bacteriana, assim como propiciarem retenção do exsudato, propriedades estas consideradas benéficas (LIPTAK, 1997).

\section{I.4 - Classificação dos curativos}

A classificação mais usada para os curativos é a que se baseia mais na natureza do material de que é feito do que no modo como é aplicado. Pelo tipo de material usado para a preparação dos curativos, eles podem ser classificados como sintéticos (derivados de produtos manufaturados ou 
desenvolvidos em laboratório) e biológicos (derivados de tecidos naturais) (PURNA, 2000).

\section{I.4.1 - Curativos sintéticos}

\section{I.4.1.1 - Convencionais}

Estes curativos são produzidos com tecido, como a gaze. Eles proporcionam pequena ou nenhuma oclusão e permitem a evaporação da umidade, resultando numa ferida excessivamente ressecada. Foi observado que, mesmo 64 camadas de gaze não conseguem evitar a contaminação da ferida por bactérias exógenas (OWENS ${ }^{3}$ apud PURNA, 2000). Isto levou à origem dos curativos compostos que são uma mistura de gaze de malhas largas impregnadas com parafina de grau médico, que resulta num curativo relativamente não-aderente. Nos anos 80 , começou a ser testada a incorporação de agentes antibacterianos, como ácido carbólico e cloridrato de mercúrio, cremes com penicilina e polimicina em combinação com curativos absorventes. Mais tarde foi iniciado o uso de polímeros de silicone em lugar da parafina, por serem menos aderentes ao ferimento, tornando suas trocas menos traumáticas. Pelo fato dos curativos convencionais apresentarem limitações na aplicação em ferimentos com grande perda de tecido, as pesquisas para a invenção de curativos mais avançados resultaram no desenvolvimento dos curativos sintéticos e biológicos (PURNA, 2000).

\section{I.4.1.2. Filmes}

São curativos homogêneos compostos por uma lâmina de polímero com adesivo em um dos lados. Eles são extremamente elásticos e transparentes. Os polímeros mais comumente usados incluem poliuretano (Figura 3), polietileno, policaprolactona, politetrafluoroetileno, dimetil aminoetil metacrilato. Exemplos desse tipo de curativo são: Tegaderm $^{\circledR}$, Dermafilm $^{\circledR}$, Opsite ${ }^{\circledR}$,

${ }^{3}$ OWENS, N. Use of pressure dressings in the treatment of burns and other wounds. Surg. Clin. North Am., v. 23, p.1354-66, 1943. 
Opraflex $^{\circledR}$, etc. Curativos de filmes são bastante apropriados para feridas superficiais, mas devido à sua falta de capacidade de absorção e por serem impermeáveis a vapores e gases causam acúmulo de fluidos por baixo do curativo, permitindo vazamento de exsudato e entrada de bactérias exógenas na superfície da ferida. Além do mais, não são convenientes para ferimentos grandes (STEPHEN, 1990).

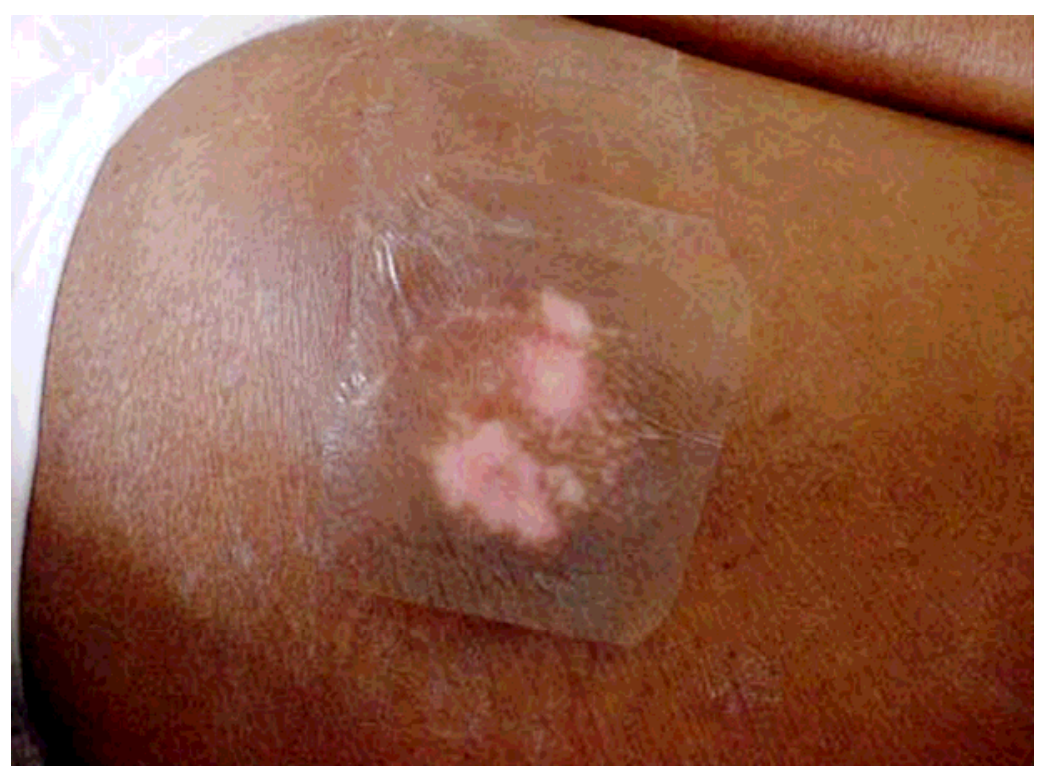

Figura 3 - Filme de poliuretano sobre úlcera de pressão estágio I (BLANES, 2004).

\section{I.4.1.3. Espumas e "sprays"}

Curativos espumosos são lâminas de soluções espumosas de polímeros como polivinilálcool e poliuretano que são superiores aos curativos de filmes por proporcionarem isolamento térmico e auxiliarem na manutenção de um ambiente úmido na superfície na ferida. Além do mais, eles são permeáveis aos gases, não-aderentes, leves e confortáveis. Têm a vantagem de se moldarem à superfície, facilitando o tratamento de feridas com cavidades irregulares. Entretanto, estes curativos são difíceis de usar em certas áreas anatômicas. Curativos em "spray" são mais confortáveis para a superfície da lesão e são totalmente portáteis. A maioria deles são copolímeros, por exemplo, Aeroplast ${ }^{\circledR}$. Outros estudos resultaram no desenvolvimento de 
curativos compostos da combinação de "spray" e espumas, por exemplo, uma espuma à base de gelatina usada sob a forma de "spray" (PURNA, 2000).

\section{I.4.1.4. Curativos compostos}

Estes curativos são laminados compostos de duas ou mais camadas. A mais externa é designada à durabilidade e elasticidade, e pode servir como controladora da taxa de evaporação de água, enquanto a mais interna é designada para máxima aderência e elasticidade. Curativos compostos podem ser classificados em:

a) Hidrocolóides - são formulações contendo um coquetel de adesivo elástico e de agentes colóides (Figura 4). Carboxi metil celulose é o ingrediente absortivo mais comum, agindo na absorção dos fluidos da lesão $\left(\right.$ Granuflex $^{\circledR}$, Epigard $^{\circledR}$, Biobrane ${ }^{\circledR}$ ).

b) Lâminas de hidrogel - são lâminas reticuladas em 3-D de polímeros hidrofílicos com ligações cruzadas, que interagem com soluções aquosas. Os polímeros mais usados são óxido de polietileno, poliacrilamida e polivinilpirrolidina. Devido a uma habilidade refrescante única, eles podem ser de grande benefício para uso nos primeiros socorros em queimaduras. Entretanto, eles são escorregadios para o manuseio e difíceis de manter em regiões de grande curvatura (dobras, cotovelos, calcanhares) (Figura 5).

c) Hidrogel amorfo - estes são semelhantes ao anterior, mas não são ligados transversalmente para formar uma lâmina tridimensional. Contém pequenas quantidades de colágeno, alginato ou complexo de carboidratos, e são únicos na habilidade de doar umidade para escaras ressecadas e facilitar o debridamento autolítico. Mas devido à viscosidade do hidrogel amorfo, pode haver dificuldade de retê-lo no sítio da ferida. Entretanto, estes curativos exibem taxas de fechamento e reepitelização mais rápidas quando comparadas com os curativos hidrocolóides (GOKOO ${ }^{4}$ apud PURNA, 2000).

\footnotetext{
${ }^{4}$ GOKOO, C.; BURHOP, K. A comparative study of wound dressings on full thickness wounds in micropigs. Decubitus. Sep. 6(5), p. 42-43, 46, 1993.
} 


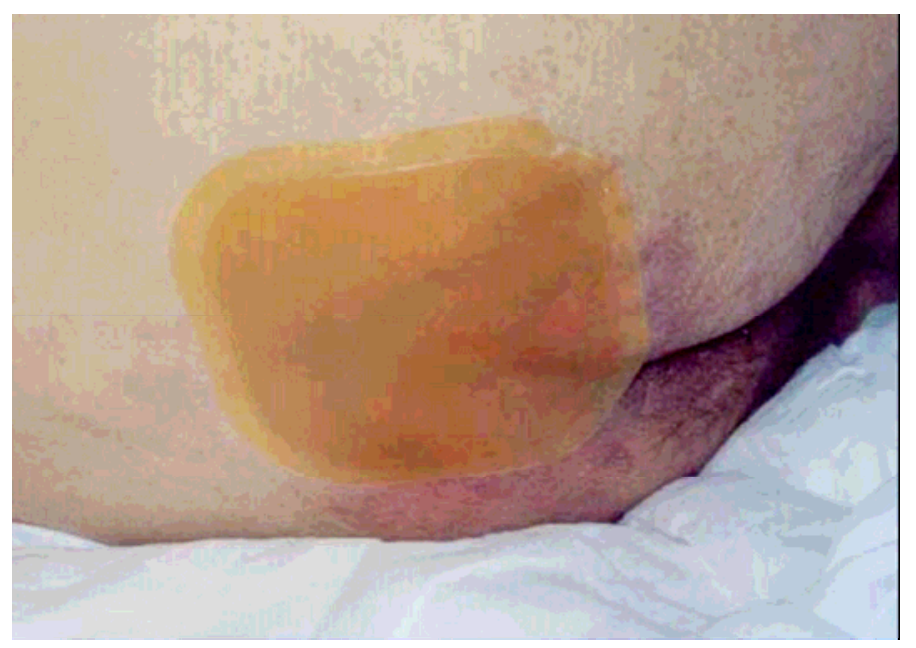

Figura 4 - Placa de hidrocolóide sobre úlcera por pressão estágio II sacral (BLANES, 2004).

d) Géis - muitos tipos de curativos em gel foram desenvolvidos. Por exemplo, o $\mathrm{HEMA}^{\circledR}$ é um hidrogel biocompatível e atóxico baseado em hidroxi etil metacrilato, o PHEMA PEG $^{\circledR}$ (Hydran) é um higrogel que se forma diretamente sobre a superfície lesada, o Geliperm ${ }^{\circledR}$ que é formado pela polimerização da agarose e da acrilamida. Outras modificações resultaram no desenvolvimento do hidrogel de oxido de polietileno com ligações cruzadas (PURNA, 2000).

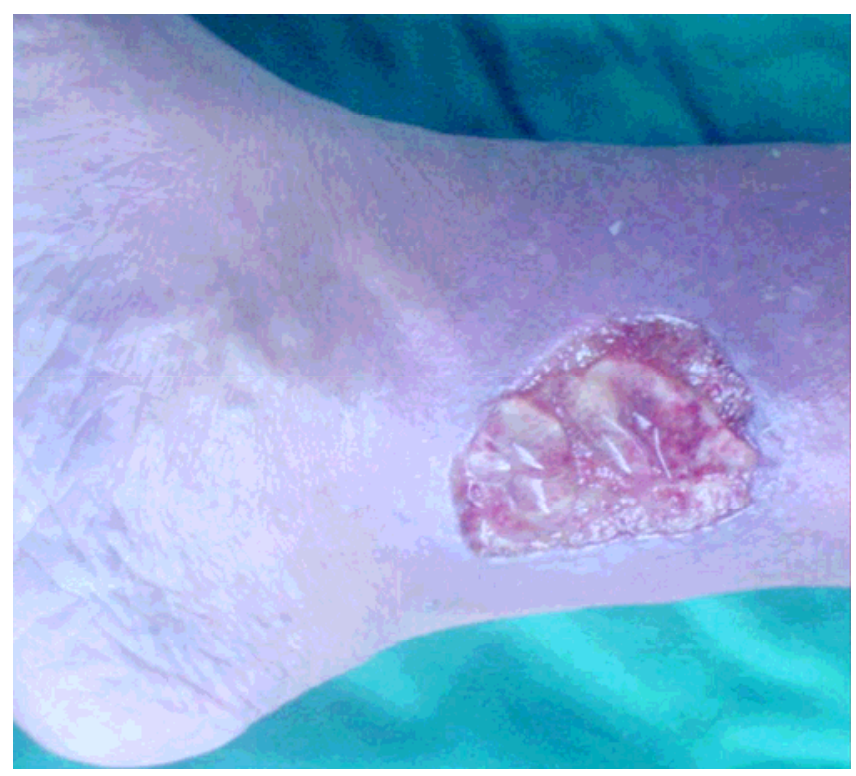

Figura 5 - Hidrogel em úlcera isquêmica de membro inferior (BLANES, 2004).

e) Super absorventes - este curativo tem uma configuração em ilha consistindo de uma porção adesiva extrafina de hidrocolóide tendo na área 
central uma trama não-absorvível cobrindo as partículas superabsorventes aderidas internamente $\left(\right.$ Combiderm $\left.{ }^{\circledR}\right)$.

Todos os curativos citados acima têm ação temporária e não auxiliam nas injúrias causadas por queimaduras extensas. Entretanto, problemas crônicos de perda de pele devem ser resolvidos pelo uso de materiais alternativos que promovam o fechamento da lesão. Este problema deu ensejo ao interesse em se desenvolver curativos biológicos (PURNA, 2000).

\section{I.4.2 Curativos biológicos}

São curativos derivados de várias formulações e combinações de colágeno, elastina e lipídeos (BARTLETT, 1981); superam de longe os curativos sintéticos (PRUITT, 1984) por realizarem as seguintes funções:

$\checkmark \quad$ restauram a barreira de vapor e previnem a desidratação da ferida;

$\checkmark \quad$ diminuem a evaporação por perda de calor;

$\checkmark \quad$ diminuem a perda de proteína e eletrólitos pelo exsudato do ferimento;

$\checkmark \quad$ previnem a contaminação bacteriana protegendo ferida e paciente da septicemia;

$\checkmark \quad$ permitem trocas menos dolorosas dos curativos;

$\checkmark \quad$ permitem um deslizamento indolor sobre as articulações;

$\checkmark$ facilitam o debridamento da ferida;

$\checkmark \quad$ promovem boa granulação no tecido que dará base para o autoenxerto em feridas profundas;

$\checkmark \quad$ podem ser usados para testar o subseqüente sucesso do autoenxerto;

$\checkmark \quad$ diminuem o tempo de cicatrização em regiões doadoras de pele para enxertos e em áreas que sofreram queimaduras com perda parcial de tecido; 
$\checkmark$ melhoram a qualidade da cicatrização, inibem a presença excessiva de fibroblastos e diminuem a contração (WINTER ${ }^{1}$ apud PURNA, 2000).

Curativos biológicos variam de aloenxerto (doadores da mesma espécie, como parentes, cadáveres), hetero-enxertos de porcos, cães e outras espécies, a membranas embrionárias, peles de embriões e recém-nascidos, filmes de colágeno reconstituído de bovinos e outras fontes, fibrina, enxerto de epiderme cultivada, enxerto de matriz dérmica e enxertos de matriz dérmica composta cultivada (PURNA, 2000).

\section{I.5 - Materiais atualmente usados e propostos para reposição de pele}

A epiderme é a mais efetiva barreira contra infecção e contra o perigo da septicemia, a qual é ainda a mais freqüente causa de morte após extensas lesões do tecido cutâneo. Já nos primeiros estágios de tratamento, entretanto, deve-se considerar que uma cobertura epidérmica sozinha não é meio suficiente para prevenir danos funcional e estético da nova pele devido à carência de estabilidade mecânica ou contrações cicatriciais, por isto sempre requere o transplante de um componente dérmico adequado (KANGESU, 1993). O substituto ideal para pele deve ser de baixo custo, podendo ser armazenamento por longo tempo e sendo utilizável após desarmazenado; deve ser não-antigênico, durável e flexível, prevenindo perda de umidade e constituindo uma barreira contra bactérias; deve ser ajustável a feridas com superfícies irregulares, podendo ser aplicado em uma única operação e não promovendo hipertrofia. Uma contribuição rumo a um substituto definitivo da pele foi feita por Green e seu grupo (GREEN, 1979), onde introduziram um método muito efetivo de cultura de células para produzir um epitélio transplantável (RHEINWALD, 1975). No entanto, a euforia gerada por esse método ficou esquecida por muito tempo, pois ele proporcionava somente a cobertura epidermal, e não uma pele com duas camadas. Recentemente, tornou-se aparente que muitos dos problemas encontrados após aplicação dessas "películas" de queratinócitos, ou seja, contrações cicatriciais ou 
instabilidade na fixação da epiderme ao tecido subjacente, poderiam ser atribuídos à ausência de um substrato dérmico. Resultados promissores foram obtidos por métodos que tinham a vantagem da baixa imunogenicidade de componentes dérmicos alogênicos (GIBSON, 1986; SHER, 1983), combinando-os com porções autogênicas de pele, como no caso do enxerto misto (YANG, 1979), ou enxerto-sanduíche (KREIS, 1989), ou com queratinócitos autogênicos cultivados in vitro (CUONO, 1986; HICKERSON, 1994). Eventualmente, o resultado de todos esses enxertos é compor uma nova pele consistindo de uma neo-epiderme autogênica no topo de uma matriz dérmica alogênica definitivamente integradas entre si.

Os modelos mais conhecidos fabricados in vitro para reposição dérmica, com qualidade reprodutível, são provavelmente a pele artificial desenvolvida por Yannas e Burke (BURKE, 1981; 1983; YANNAS, 1980) e a desenvolvida por Bell (BELL, 1981). Ambos começam com uma matriz colagênica que, depois de transplantada, se torna vascularizada e colonizada por células vindas da superfície da ferida, pois suas estruturas química e física funcionam como um esqueleto que permite a invasão celular, o que leva a se transformar numa pele substituta. Esses modelos já foram bem testados em ensaios clínicos, mas ainda existem problemas, como a rápida degradação proteolítica após o enxerto (WASSERMANN, 1988) ou a formação de cicatrizes nas margens da ferida e em áreas onde a derme artificial não foi perfeita. A ocorrência de uma prolongada instabilidade entre o enxerto e a cobertura epidérmica definitiva também foi um problema freqüentemente relatado (DESAI, 1991; RUE, 1993).

Materiais à base de colágeno estão sendo investigados para reparos cirúrgicos por causa de sua baixa antigenicidade inerente e sua habilidade de se integrar com os tecidos adjacentes. Esses materiais derivados do colágeno, proveniente de submucosa do intestino delgado de porcos, têm sido usados com resultados promissores em reparos experimentais da parede abdominal. Eles também têm sido avaliados como biomaterial para uma variedade de outras aplicações em reparos teciduais ou substituição, incluindo o reparo de tendões e bexiga urinária. A submucosa intestinal parece possuir os requisitos biocompatibilidade e elasticidade para reparos cirúrgicos e pode ser remodelada pelo tecido adjacente (ABRAHAM , 2000). 
O fato é que, até o presente momento, não há disponível um substituinte dérmico artificialmente produzido que tenha sido testado o bastante em experimentos animais ou em clínica, ou que seja de qualidade comparável à derme autogênica nativa (HAFEMANN, 1999).

\section{I.6 - Biomateriais}

O termo biomaterial pode ser aplicado a qualquer substância ou combinação de substâncias, de origem natural ou sintética, que seja farmacologicamente inerte e tenha aplicação orgânica, desenvolvida para ser implantada e/ou incorporada em um período de tempo, podendo servir ou não como matriz, veículo, suporte ou estimulador para o crescimento de novo tecido, onde houve perda de matéria viva ou de sua função (WILLIAM, 1987).

As pesquisas e utilização desses materiais na área médica têm conseguido grandes avanços nos últimos anos, graças a um melhor entendimento dos mecanismos de interação do material com os tecidos do corpo. O maior objetivo dos profissionais é produzir materiais, para fins médicos, que sejam compatíveis, duráveis e funcionais quando em interação com sistemas biológicos.

A natureza química de um biomaterial é uma característica fundamental que o classifica em duas grandes categorias:

- $\quad$ naturais: colágeno, seda, queratina ou polissacarídeos;

- sintéticos: cerâmicas, polímeros sintéticos, metais e ligas metálicas, e materiais compósitos, ou seja, aqueles formados pela interação de dois ou mais materiais.

Um biomaterial deve apresentar uma série de características, dentre as quais, as mais importantes: biocompatibilidade, biofuncionalidade, biodegradabilidade, atoxicidade, não-carcinogenicidade, hipoalergenicidade, além de apresentar densidade e peso adequados, inércia, estabilidades química e biológica controladas, resistência mecânica e elasticidade apropriadas, ser reprodutível, de fácil obtenção e com um custo razoável. Do ponto de vista biológico, as mais importantes são biocompatibilidade e biofuncionalidade, uma vez que um biomaterial não deve ser reconhecido como 
corpo estranho pelo organismo tratado, ou este desencadeará processos de defesa, inflamatórios e imunológicos, visando sua eliminação (SILVER, 1989). Dependendo da aplicação, a biodegradabilidade também se faz de grande importância, como no uso em suportes de crescimento de tecidos e em liberação de drogas, uma vez que sua retirada seria desnecessária por haver degradação da matriz.

\section{I.7 - Colágeno}

O colágeno é uma proteína estável, sintetizada por células do tecido conjuntivo denominadas fibroblastos. Por ser estável, sua renovação é muito lenta, mas o ritmo de seu turnover varia de um órgão para outro. Por exemplo, o colágeno dos tendões quase não é renovado, enquanto que o do conjuntivo frouxo renova-se em ritmo relativamente rápido. A deficiência de vitamina $C$ impede a síntese de colágeno pelos fibroblastos, de modo que as fibras removidas não podem ser substituídas. A conseqüência é uma degeneração generalizada do tecido conjuntivo, mais acentuada nos locais onde a renovação do colágeno é mais acelerada como, por exemplo, o ligamento que prende os dentes em seus alvéolos que apresenta uma rápida renovação de colágeno; conseqüentemente, esse ligamento em geral é afetado no escorbuto. A destruição fisiológica do colágeno é promovida pela ação da enzima colagenase, produzida por células do tecido conjuntivo. Essa enzima digere exclusivamente o colágeno, não atacando, portanto, outras proteínas e é ativa no $\mathrm{pH}$ normal dos tecidos (pH em torno de 7) (JUNQUEIRA, 1990).

O colágeno é a proteína mais abundante do tecido conjuntivo, podendo ser encontrado na pele, em ossos, tendões e dentes. Suas propriedades diferem de acordo com o tipo de organização das fibras que o constituem. Tem como principal característica a formação de fibras insolúveis que possuem alta força elástica, o que o torna o principal responsável pela modulação das forças exercidas sobre o organismo (Figura 6). Além de desempenhar importante papel na estrutura dos tecidos, o colágeno é capaz de orientar a formação de tecidos em desenvolvimento (WILLIAM, 1987) fato altamente favorável na sua utilização como biomaterial (SILVER, 1989). 


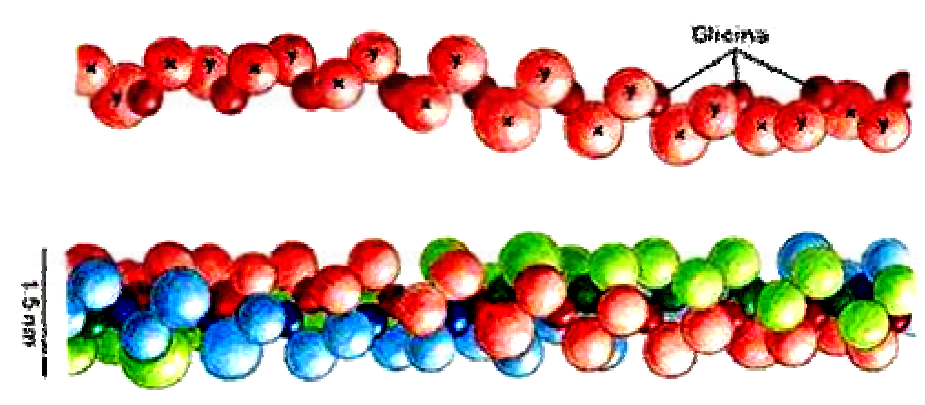

Figura 6 - Molécula de colágeno.

Devido às suas várias propriedades físico-químicas (reticulação variável, que controla o grau de embebição), físico-mecânicas (entrelaçamento ou orientação das fibras) e biológicas (antigenicidade mínima, reduzida por tratamento com enzimas ou por reticulação), o colágeno é largamente utilizado como material para implante tanto na forma pura como géis de colágeno (FRIESS, 2001), ou ainda associado a outras moléculas, como polissacarídeos biológicos e microbianos (DE PAULA, 2002).

Colágeno tem sido usado para diversas aplicações no campo biomédico, o que pode ser atribuído à sua alta resistência à tensão, biodegradabilidade controlada, propriedades hemostáticas, não-citotoxicidade, baixa antigenicidade e características não-inflamatórias (GOISSIS, 1996). Colágeno reconstituído tem sido aplicado em uma variedade de problemas cirúrgicos, incluindo hemostasia (CRITESCU, 1087), queimadura e revestimento de feridas (YANNAS, 1980), regeneração nervosa (RADHIKA, 1999), reconstrução tecidual (ALPASLAN, 1997), cirurgia do trato urinário e reparação de hérnias. Também tem sido aplicado em sistema de liberação de drogas (ELLIS,1996; KNAPP, 1983), barreira vaginal contraceptiva, válvulas cardíacas (RUBIN, 1973) e enxertos vasculares (SLATTER, 1982).

Tanto o colágeno como os produtos de sua degradação, foram reconhecidos como quimicamente atrativos por vários tipos de células. Seu papel na cicatrização de feridas é bem delineado. Estudos de culturas realizadas in vitro demonstraram claramente que o colágeno, sendo um substrato natural para células, é altamente essencial para mantê-las com sua morfologia e fenótipo normais, em cultura. A matriz de colágeno oferece uma 
estrutura suporte biointerativa, a qual guia e estimula apropriada formação tecidual (LEE, 2001).

\section{I.7.1. Colágeno tipo I}

O colágeno mais conhecido química e estruturalmente é o do tipo I, facilmente encontrado na pele, nos tendões, ossos, dentes, vasos sanguíneos e intestinos. A macromolécula de colágeno tem sua estrutura formada por uma unidade monomérica, denominada tropocolágeno, consistindo de três cadeias polipeptídicas de mesmo tamanho denominadas $\alpha$, sendo duas iguais $\left(\alpha_{1}\right)$ e uma diferenciada ( $\left.\alpha_{2}\right)$. Estas se entrelaçam formando uma estrutura helicoidal ligadas entre si por pontes de hidrogênio, o que se conhece por tripla hélice. Cada uma dessas cadeias a contém 1055 ( $\left.\alpha_{1}\right)$ e 1029 ( $\left.\alpha_{2}\right)$ resíduos de aminoácidos, e a seqüência destes é notavelmente regular, apresentando-se na forma de unidades repetitivas, os tripletes do tipo: (-Gly-X-Pro-) $n$ ou (-Gly-XHypro- $)_{n}$, onde $X$ é um aminoácido qualquer, essencial para a organização do colágeno em fibras (LIGHT, 1980; SMITH, 1968). Esta seqüência de resíduos, resulta em uma proteína com um conteúdo de glicina (Gly) de 33\%, prolina (Pro) 12\% e hidroxiprolina (Hyp) 11\% (Figura 7). As extremidades não são helicoidais, e são denominadas de telopeptídeos $\mathrm{N}$ e C-terminais, que possuem respectivamente 16 e 25 resíduos de aminoácidos (PROCKOP, 1995; TRAUB, 1971). 


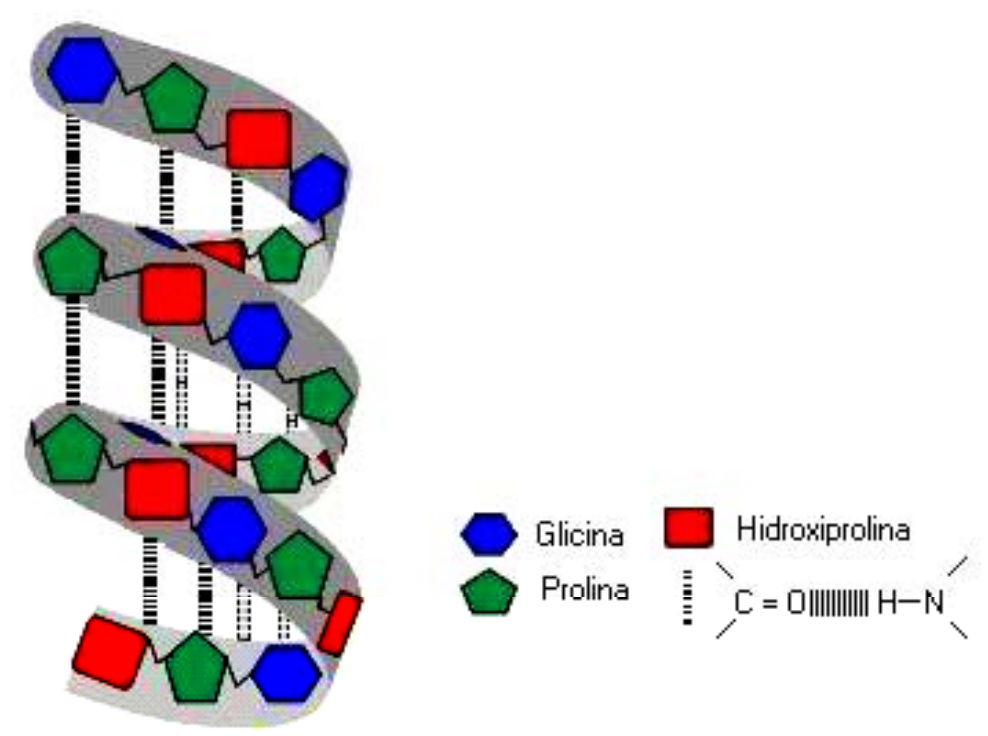

Figura 7 - Estrutura da molécula de colágeno.

Através das interações entre as cadeias de tropocolágeno, tem-se a formação das microfibrilas (MAYNE, 1987), a menor unidade estrutural do tecido conjuntivo, que podem ser vistas em microscópio eletrônico de varredura como um filamento fino de $4 \mathrm{~nm}$. Neste modelo, as moléculas de tropocolágeno estão deslocadas um quarto em relação à molécula adjacente, apresentando também uma região de espaçamento vazio entre duas moléculas alinhadas longitudinalmente ("gap"), seguidas de uma região de sobreposição ("overlap") destas moléculas (Figura 8). 


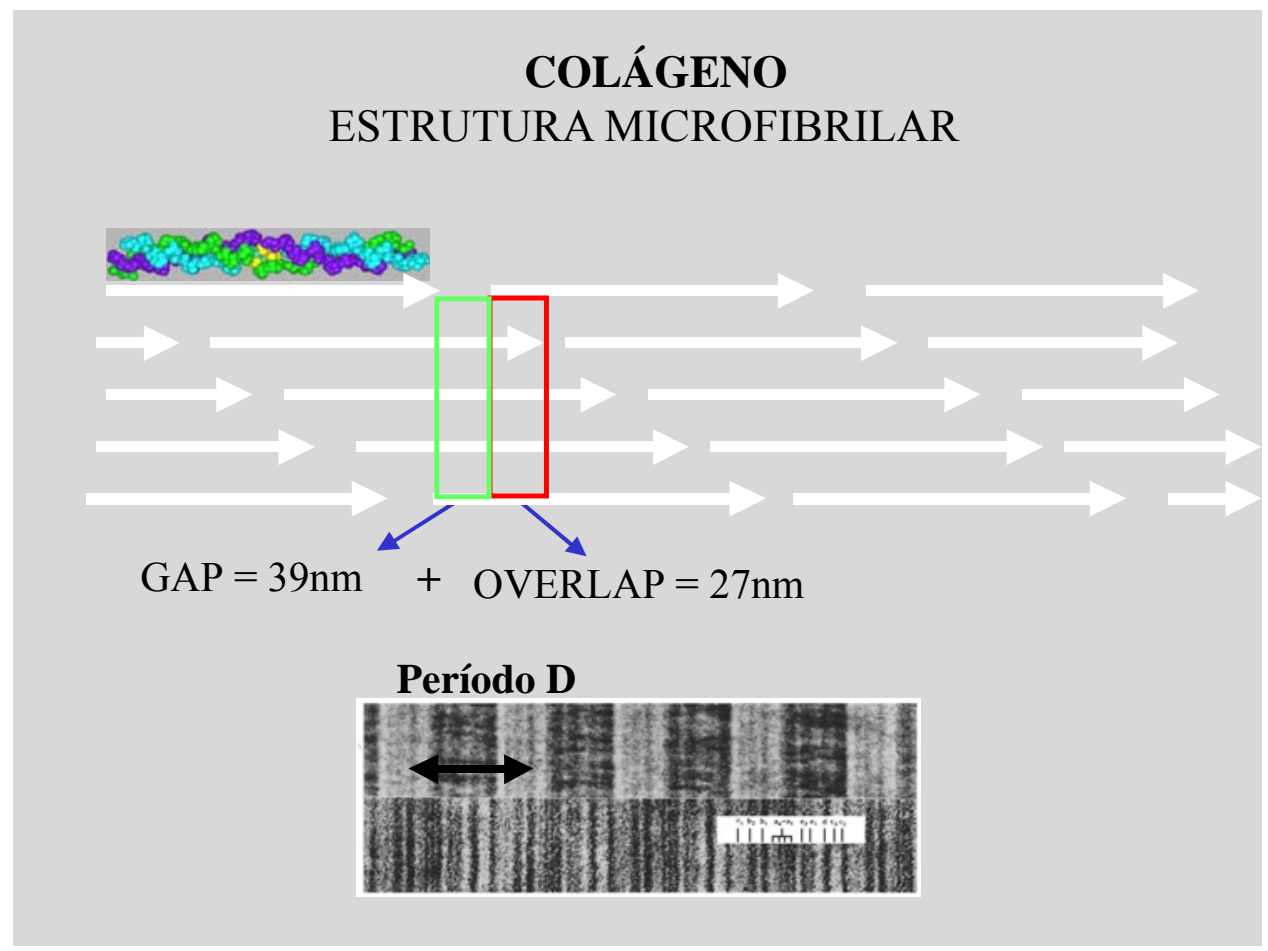

Figura 8 - Disposição das microfibrilas de colágeno.

Depois de formadas as microfibrilas inicia-se o processo de agregação denominado fibrilogênese, para formação das fibras insolúveis (Figura 9).

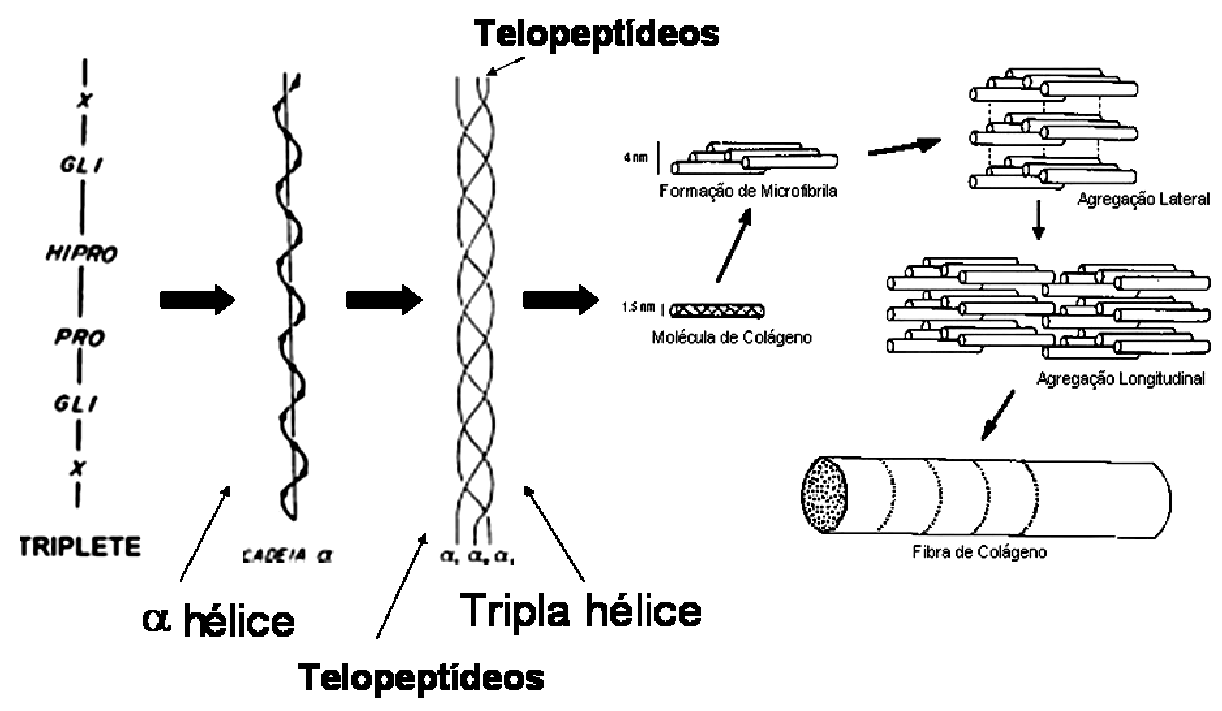

Figura 9 - Formação da fibra de colágeno. 


\section{I.7.2. Colágeno aniônico}

A formação das fibras para o colágeno nativo ocorre em $\mathrm{pH} 7,0$, portanto, este é o $\mathrm{pH}$ em que se tem a máxima interação eletrostática entre as moléculas de tropocolágeno, fazendo com que a resultante de cargas na molécula seja zero. A resultante das cargas pode ser modificada no colágeno, resultando em uma molécula carregada positiva ou negativamente, dependendo do processo químico com o qual o biomaterial for tratado. Matrizes carregadas positivamente (matrizes catiônicas) são utilizadas como suporte para crescimento celular, porém, são altamente trombogênicas se comparadas às matrizes nativas, o que restringe seu uso como biomaterial. Matrizes carregadas negativamente (matrizes aniônicas), além de serem empregadas como suporte para crescimento de tecido ósseo, são eficientes em sistemas de liberação de drogas catiônicas, baseado nas propriedades de troca iônica (HUC, 1985). O colágeno pode ser obtido na sua forma solúvel por processos físico-químicos (NIMNI, 1988), químicos (GOISSIS, 1996) e enzimáticos (KATO, 1993).

Um outro processo para a preparação de materiais de colágeno carregados negativamente a pH 7,4, utilizado neste trabalho, é a hidrólise seletiva dos grupos carboxiamidas dos resíduos de aminoácidos asparagina (Asn) e glutamina (GIn) presentes nas cadeias $\alpha$ do colágeno tipo I (GOISSIS, 1996) (Figura 10). Como resultado, foi observado que a reação de hidrólise promove alterações no padrão da organização da estrutura microfibrilar da matriz colagênica, que estão relacionadas com o rompimento das ligações cruzadas do tecido e também com o novo padrão de interações eletrostáticas, que ocorre em função do aumento de cargas negativas da matriz. Este aumento inibe significativamente a habilidade de moléculas de colágeno em formar fibrilas, tendo uma completa inibição após 96 horas de hidrólise. (BET, 2001). 


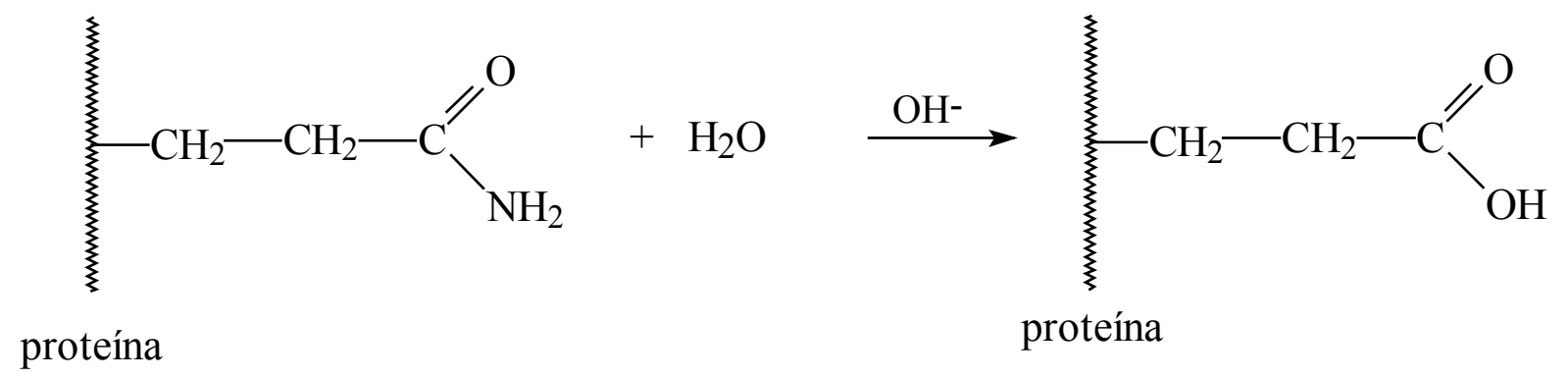

Figura 10 - Esquema da hidrólise dos resíduos de glutamina em meio básico.

\section{I.7.3. Curativos à base de colágeno}

O desenvolvimento de curativos à base de colágeno é racional em vista de suas características funcionais e estruturais únicas. O termo colágeno é geralmente aplicado a uma série de macromoléculas quimicamente distintas já relatadas. A capacidade de formar agregados supramoleculares nos espaços extracelulares é uma das propriedades características das moléculas pertencentes às proteínas da família do colágeno. A diversidade fibrilar em sua estrutura está relacionada às propriedades estrutural e mecânica características de cada tecido. Além de proporcionar suporte mecânico ao tecido conectivo, o colágeno também compõe um substrato essencial para migração e adesão das células, sendo considerado um importante fator morfogenético no desenvolvimento embrionário e no processo regenerativo. A natureza hidrofílica do colágeno atribuída à sua estrutura molecular caracterizada pela vasta presença de aminoácidos diamino dicarboxílicos e partes de carbohidratos promovem uma geometria de superfície muito atrativa para a adesão celular. Além disso, outro fator que promove a atração de células fibrogênicas aos implantes de colágeno é a presença de glicoproteínas sobre a superfície das células. Estas moléculas têm uma grande afinidade por colágeno e se ligam especificamente com regiões definidas da superfície do mesmo. Todas estas características especiais do colágeno estimularam seu uso no desenvolvimento de vários tipos de curativos (PURNA, 2000).

\section{I.7.4. Tipos de curativos à base de colágeno}


Uma excelente revisão dos curativos à base de colágeno foi feita por Purna (PURNA, 2000), onde cita que a preparação do colágeno para uso como um biomaterial pode se dividida em duas maneiras principais. Na primeira, as estruturas biológicas são tratadas de modo a remover outros materiais e reforçar o colágeno restante sem interferir na estrutura existente e nas ligações intermoleculares cruzadas. Na segunda, o colágeno é solubilizado e purificado e não se medem esforços na tentativa de melhorar e repolimerizar o material para deixá-lo na configuração adequada.

A primeira opção tem a vantagem de aproveitar-se da estrutura tridimensional, biológica e normal do biomaterial, mas tem a desvantagem de produzir um material que apresenta configurações relativamente fixadas e predeterminadas. O segundo método oferece um potencial mais amplo e geralmente tem sido preferido.

As principais formas dos curativos à base de colágeno que têm sido usados em aplicações médicas são:

a) Fibras de colágeno extrudadas - suturas com colágeno e fibras extrudadas foram usadas para recobrir as áreas expostas da pele durante a Segunda Guerra Mundial. A reação histológica provocada por esse tratamento primariamente consiste de infiltrado histiocítico e eventual resposta fibroblástica.

b) Esponja de colágeno - materiais à base de colágeno formando esponjas tridimensionais; funcionam como curativo devido à presença de grandes poros ou canais, comunicações intercanais e combinações de macromoléculas do tecido conectivo aumentando a infiltração in vivo no tecido lesado tanto quanto estimulam o crescimento celular in vitro. As esponjas têm sido usadas tanto para cobertura temporária quanto permanente de defeitos dérmicos em animais e humanos. O desenvolvimento celular dentro da esponja depende da porosidade e da presença de uma estrutura fibrosa. Elas eram normalmente preparadas por congelamento à vácuo de uma dispersão de colágeno em meio ácido. Após adição de baixos níveis de hialuronato e fibronectina modificada à estrutura do implante ocorreu um aumento na químioatração, replicação e deposição de colágeno em modelo de cicatrização de feridas in vivo. Pesquisas também foram direcionadas com intuito de melhorar a utilidade das esponjas combinando-as com outros princípios 
cicatrizantes. Um substituto dérmico halogênico cultivado, composto de fibrobastos, presente na matriz da esponja proporciona um ambiente favorável para a cura da ferida. Deste modo, a grande vantagem da aplicação da esponja de colágeno como curativo reside no fato de que, após cicatrizadas, as feridas apresentam uma aparência melhor quando analisadas visualmente.

c) Filme de colágeno - os filmes são feitos depositando o colágeno sobre superfícies de metacrilato. A implantação em animais mostrou que membranas de colágeno com ligações cruzadas estimulam uma resposta inflamatória muito sutil ou nenhuma e causam a aderência de fibroblastos à superfície do colágeno. Filmes de colágeno, quando tratados com irradiações UV para gerar as ligações cruzadas estimularam nenhuma reação inflamatória. Estes filmes são rapidamente infiltrados com glicoproteínas locais e são gradualmente substituídas pelo tecido hospedeiro. Como estes filmes são muito finos e difíceis de manusear, houve a necessidade de reforçá-los embutindo uma malha de nylon. Isto serviu como um curativo potencial para queimaduras de segundo e terceiro graus por terem exibido rápida epitelização com pequena atividade inflamatória e densa fibrose de tecidos infiltrados nas camadas subdermais. Um curativo misto de membrana de colágeno e esponja de colágeno contendo no meio e na parte superior uma camada antibacteriana de limitada hidrofobicidade demostrou também grande eficiência (PURNA, 2000).

\section{I.7.4.1. Matriz de colágeno proveniente da submucosa de intestino delgado de porco}

Muitas pesquisas estão sendo realizadas com diversos substratos de tecidos naturais na tentativa de desenvolver biomateriais avançados. Um destes biomateriais que está sendo extensivamente usado é a submucosa de intestino delgado porcina (Small Intestinal Submucosa - SIS), que tem demonstrado ser um tecido resistente e maleável capaz de servir como suporte para o crescimento de células no reparo e substituição de tecidos lesados. A SIS é uma matriz complexa e natural de fácil manuseio, com resistência suficiente para suportar a tensão de suturas e prover um suporte para tecidos friáveis. Ela é obtida de uma fonte biológica e é processada para que todas as 
células sejam removidas, sem que sua estrutura seja comprometida. Além disso, é esterilizada para que fique livre de patógenos e possa ser armazenada por longo período sem sofrer degradação, sendo biocompatível e segura para uso e humanos (BADYLAK, 1999).

Analisando o intestino delgado, a camada submucosa está presente entre as camadas mucosa e muscular do intestino, proporcionando elasticidade por ter colágeno em sua estrutura, apresentando-se sob a forma de uma matriz fibrosa. Devido às suas características, a SIS é apropriada para suportar a incorporação de tecidos em muitos procedimentos cirúrgicos e é preparada de modo a servir de base para o processo de remodelamento cicatricial. Ela tem sido usada em milhares de pacientes para todo tipo de restauração tecidual, como na área de uroginecologia onde é aplicada no reparo da uretra para tratamento de incontinência urinária e reconstrução da base pélvica, no reparo de hérnias ventrais e inguinais e no tratamento de feridas $\left(\mathrm{COOK}^{\circledR} \mathrm{SIS}^{\circledR}\right.$ Technology) (BADYLAK, 1999).

Diferentes biomateriais têm sido usados como suporte no reparo de tecidos, sendo cada tipo selecionado para o uso mais adequado, conforme suas características e propriedades, mas uma habilidade comum aos que são efetivamente incorporados (absorvidos e degradados) pelo tecido receptor é a da angiogênese (servir de suporte para o crescimento de novos vasos sanguíneos). Isto é necessário para que ocorra a nutrição das células que irão preencher o tecido-suporte, para que os produtos da degradação destas células sejam eliminados e para que as células de defesa tenham acesso ao local, evitando a contaminação por agentes infecciosos (BADYLAK, 1999).

O material acelular que serve de suporte para o crescimento celular e é derivado da camada submucosa do intestino de porco (SIS) demonstrou ser rapidamente reabsorvido, suportar um abundante e precoce crescimento de vasos sanguíneos e servir como base para um remodelamento na construção de muitos tecidos do corpo incluindo estruturas músculo-esqueléticas, pele, parede abdominal, dura-máter, bexiga urinária e vasos sanguíneos (BADYLAK, 1999).

Macroscopicamente, a SIS (Figura 11) parece ser muito semelhante à membrana derivada de serosa utilizada neste trabalho (preparada à partir da tripa de porco adquirida em açougues), o que vem estimular ainda mais o 
interesse na obtenção de resultados suficientes para que ambas possam ser no futuro diretamente comparadas.

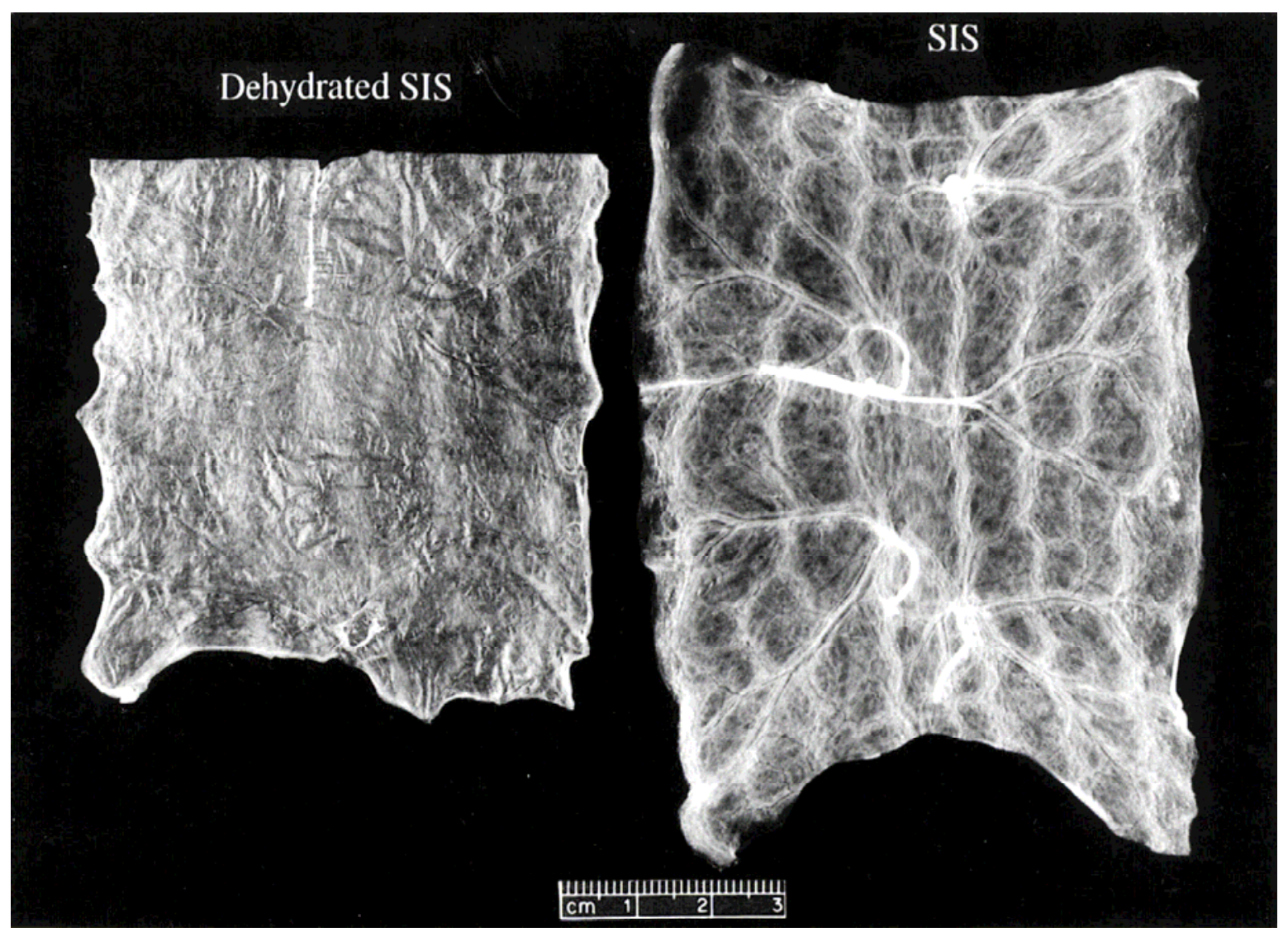

Figura 11 - Aspecto macroscópico da SIS desidratada (à esquerda) e após hidratação (à direita) (BADYLAK, 1999). 


\section{I.7.5 - Benefícios do colágeno para cura de feridas}

Os efeitos benéficos para a cicatrização de feridas pelo uso de biomateriais como géis, esponjas e filmes contendo colágeno podem ser resumidos como se segue:

$>\quad$ - o colágeno exógeno funciona como um substrato para hemostasia e quimiotaxia para elementos celulares envolvidos na cicatrização como os granulócitos, macrófagos e fibroblastos.

- os materiais à base de colágeno promovem a maturação da ferida por fornecerem um suporte para uma transição mais rápida à produção do colágeno maduro e seu alinhamento.

$>\quad$ - biomateriais são resistentes à degradação e funcionam como suporte para a adesão, migração e proliferação celular.

Os componentes moleculares da matriz extracelular são compostos primariamente de colágenos, proteoglicanas, glicoproteínas e pequenas quantidades de outras proteínas, sendo que as fibras de colágeno fornecem suporte estrutural e são conhecidas por ligar as células. Tanto as células epiteliais quanto mesenquimais possuem receptores distintos para identificação do colágeno. O crescimento, morfologia e diferenciação de uma variedade de células são influenciados pelo colágeno, talvez devido à sua capacidade de adesão. Fibronectina e laminina são glicoproteínas da matriz que unem as proteoglicanas e os receptores de superfície especificamente ao colágeno. Fibronectina promove a adesão de células mesenquimais às membranas intersticial e basal do colágeno. Por isso o uso do colágeno na forma de filmes e géis como um substrato para cultura de células representa uma base para investigação sob muitos aspectos dos fenômenos celulares e funcionais como adesão, migração, crescimento e diferenciação celular (PURNA, 2000). 
O desenvolvimento de enxertos epidermais cultivados em conjunto com matriz colagênica para tratar pacientes com a vida ameaçada por extensas queimaduras é uma tecnologia com potencial para produzir os melhores materiais para curativos e reparos, fornecendo aos pacientes células de sua própria pele, aderidas sobre uma matriz compatível e organizada. Curativos à base de colágeno podem, então, ser considerados como tendo todo potencial para satisfazer as exigências de um curativo ideal por promoverem um ambiente na superfície da ferida no qual a cicatrização poderá ocorrer com uma taxa máxima de consistência, produzindo uma lesão curada com uma aparência cosmeticamente aceitável (STEPHEN, 1990). 


\section{OBJETIVOS}

Em decorrência da busca de materiais que possam otimizar o processo cicatricial, e sendo o colágeno um ícone das pesquisas nesta direção, este trabalho tem como objetivo os seguintes pontos:

> Avaliar as propriedades reológicas da mistura creme/gel de colágeno, testando sua estabilidade após o preparo.

$>\quad$ Determinar adequado protocolo para os testes in vivo.

> Testar uma matriz de colágeno aniônico, obtida a partir de serosa porcina por tratamento alcalino, sob a forma de gel associada a um creme comercial.

$>\quad$ Analisar o comportamento de uma matriz de colágeno sob a forma de membrana, obtida a partir de serosa porcina por tratamento alcalino, durante o experimento como curativo biológico oclusivo na cicatrização das feridas planas produzidas em peles de ratos.

$>$ Comparar visual e histologicamente os diferentes tratamentos em relação ao tempo de cicatrização, ao desenvolvimento do processo cicatricial e à qualidade do tecido neoformado em cada tratamento proposto. 


\section{MATERIAIS E MÉTODOS}

O colágeno foi o biomaterial eleito para este trabalho por concentrar importantes características, como: baixo índice de irritabilidade ou alergenicidade $(2 \%)$, biodegradabilidade, habilidade em promover crescimento celular e ser de fácil obtenção. Além do mais, a matriz obtida de serosa porcina foi pouco explorada e poderá ser uma alternativa para a já conhecida matriz obtida da submucosa de intestino delgado (Small Intestinal Submucosa - SIS).

\section{III.1. Obtenção do gel de colágeno aniônico}

O gel foi cedido para este trabalho pelo grupo do Laboratório de Bioquímica e Biomateriais do Instituto de Química de São Carlos. Serosas de dimensões $10 \mathrm{x}$ $10 \mathrm{~cm}$ foram tratadas a $20^{\circ} \mathrm{C}$ com uma solução fortemente alcalina $(\mathrm{pH} \cong 13)$ contendo sulfatos, hidróxidos e cloretos de cálcio, potássio e sódio, durante 96 horas. Em seguida, foi feita a estabilização dos materiais com uma solução neutra, também contendo cloretos e sulfatos dos cátions acima citados por um período de 6 horas, certificando-se que o $\mathrm{pH}$ final estivesse entre 8,0 e 8,5.

$O$ excesso de sais residuais ainda presentes foram removidos por lavagens sucessivas com ácido bórico a 3\% (3 vezes em 6 horas), EDTA 0,3\% a pH 11 (3 vezes em 6 horas) e água destilada (6 vezes em 2 horas), seguido da estabilização do material em tampão fosfato $0,13 \mathrm{~mol} \cdot \mathrm{L}^{-1}, \mathrm{pH} 7,4$ para a preparação da membrana ou seguido da dissolução em ácido acético a pH 3,5, resultando num gel de colágeno a 1\%. (MARTINS, 1998).

\section{III.2. Creme}

Os cremes são formas farmacêuticas, de uso externo, tendo por base uma ou mais substâncias gordurosas (vaselina, lanolina, lano-vaselina, etc.) e resinosas emulsionadas com água $(30-60 \%)$ em batedores de alta velocidade, às quais se incorporam princípios ativos. Têm-se cremes do tipo óleo em água ( $a$ 
grande maioria dos cremes) e do tipo água em óleo, necessitando na sua elaboração de emulsionantes hidrossolúveis ou oleossolúveis. Eles lubrificam e amolecem a pele áspera propiciando, ainda, uma cobertura protetora que reduz o contato com o meio, podendo, também, mormente os oclusivos, reduzir a perda de água. Podem servir para o "transporte" de princípios ativos através do óstio folicular e por mantê-los em íntimo contato com a camada córnea. Eles têm a vantagem de serem facilmente aplicáveis, propiciarem proteção mecânica, suavizarem e amaciarem a pele. Dentre as desvantagens de seus empregos enumeram-se a retenção de calor, o engorduramento da pele, a retenção de sujeira aderida, a oclusão osteo-folicular, acarretando pela ação comedogênica, a ocorrência de foliculite e de furunculoses. Os cremes devem ser empregados com massageamento do local, várias vezes ao dia. Seu uso deve ser restrito a lesões pequenas e em áreas localizadas. Geralmente, a eles se associam princípios ativos com ação antimicrobiana e antiinflamatória (SPINOSA, 1999).

\section{III.2.1. Preparação do creme com colágeno}

A preparação envolveu a mistura de um creme hidratante (Creme Universal Merck ${ }^{\circledR}$ ) com o gel de colágeno na proporção de 90:10 em massa (creme:gel de colágeno). O creme foi pesado e espalhado em um recipiente de vidro onde, após pesagem, foi colocado o gel de colágeno a $1 \%$. Ambos foram cuidadosamente misturados com uma espátula, em movimentos de vaivém, até que se obtivesse aparência e consistência homogêneas. Depois o recipiente e seu conteúdo foram submetidos à esterilização por radiações de ultravioleta, em capela de fluxo laminar durante 50 minutos. Em seguida, a mistura foi acondicionada em frasco opaco e estéril e conservada em geladeira até o uso.

\section{III.2.2. Caracterização reológica do creme}

Os estudos foram realizados em um reômetro de tensão controlada (AR1000N - TA Instruments) com sistema de placas paralelas (40mm, gap 1200 $\mu \mathrm{m})$, 
na temperatura de $37^{\circ} \mathrm{C}$. A região viscoelástica foi obtida através de varredura de tensão de 0,5 a $200 \mathrm{~Pa}$, onde G' e G" foram medidos como função da deformação à freqüência constante de $1,0 \mathrm{~Hz}$. Os ensaios de viscosidade foram efetuados com variação do cisalhamento de 0,02 a $1000 \mathrm{~s}^{-1}$, na temperatura $37^{\circ} \mathrm{C}$. A estabilidade do creme foi examinada por um período de 70 dias em duas condições diferentes de armazenamento: temperatura ambiente $\left(\mathrm{TA}, \sim 25^{\circ} \mathrm{C}\right)$ e geladeira $\left(\sim 5^{\circ} \mathrm{C}\right)$. As medidas foram feitas no máximo dois dias após a preparação do creme e após 70 dias de armazenamento.

\section{III.3. Obtenção da membrana de colágeno}

A preparação da membrana de colágeno derivada de serosa porcina foi feita pelo aluno de Iniciação Científica Isequiel dos Santos Mendes e cedida para este experimento.

A matriz extracelular de colágeno foi obtida por tratamento alcalino em serosa porcina por 24h. Este tratamento provoca a hidrólise dos grupos carboxiamidas dos resíduos de asparagina e glutamina presentes na molécula do tropocolágeno. As matrizes obtidas foram caracterizadas por microscopia eletrônica de varredura, estabilidade térmica, estabilidade biológica, absorção de água e espectroscopia na região do Infravermelho (MENDES, 2003).

\section{III.4. Microscopia eletrônica de varredura (MEV)}

As amostras de serosa acelularizadas, por se tratarem de tecido conjuntivo rico em fibras colágenas, foram estudadas por esta técnica a fim de complementar as observações de DSC, principalmente para avaliar os níveis de alteração da estrutura microfibrilar da matriz colagênica. As amostras, de cerca de $0,8 \mathrm{~cm}$ de diâmetro foram lavadas previamente com água destilada, para remoção do tampão fosfato, seguido de lavagens com soluções de etanol/água 15, 30, 50, 70, 95\% e solvente puro e acetona:etanol nas mesmas proporções. A lavagem com 
solventes orgânicos tem como objetivo a desidratação gradual do total das amostras, sem perdas significativas de estrutura da matriz colagênica.

As fotomicrografias foram obtidas com auxílio dos equipamentos: microscópio eletrônico de varredura Carl Zeiss modelo DSN 960, Metalizador (“Sputter Coater”) Balzers modelo SDC 050 e suportes de alumínio para MEV.

Para a obtenção das fotomicrografias da seção transversal da matriz colagênica, os pedaços cortados foram colocados na posição vertical entre as partes do suporte plástico, para o auxílio na fixação vertical. Foram feitas fotomicrografias também da parte superior da matriz. Os materiais foram recobertos com uma fina camada de ouro $(30 \mathrm{~nm})$.

\section{III.5. Procedimento in vivo (Rattus norvegicus)}

Os animais foram mantidos em gaiolas individuais para se evitar o canibalismo, e receberam ração industrializada para ratos e água ad libidum. Tratava-se de ratos machos, pesando entre 250 e 350 gramas.

Os animais receberam anestesia geral intramuscular de uma associação de Quetamina (30 mg/Kg de peso) e Xilasina (6 mg/Kg de peso), foram tricotomizados na região tóraco-dorsal (de ambos os lados) e, em seguida, foram submetidos à excisão cirúrgica de um "flap" de pele, cuidando-se para que todas as camadas da mesma fossem removidas, restando apenas a musculatura subjacente. O dia da cirurgia foi considerado dia 0 (zero). A região tóraco-dorsal foi escolhida para que os animais não conseguissem alcançar os ferimentos com a própria boca, o que poderia interferir no processo de cicatrização.

As lesões do lado esquerdo foram escolhidas para o grupo de controle e as lesões do lado direito receberam os tratamentos em estudo.

A eutanásia foi realizada por overdose dos medicamentos anestésicos acima mencionados, seguida de aplicação de cloreto de potássio intracardíaca nos dias determinados. 


\section{III.5.1. Piloto I}

Um estudo piloto foi realizado previamente com 10 (dez) ratos para que a eficiência do procedimento cirúrgico, do protocolo de tratamento e da coleta de material fosse avaliada. O grupo de controle recebeu apenas limpeza com solução fisiológica e o grupo tratado recebeu os tratamentos propostos: aplicação do creme com colágeno e sutura da membrana. O tamanho da lesão foi padronizado em $10 \times 10 \mathrm{~mm}$. A princípio foram estabelecidos 15 dias de tratamento, com coleta de material nos $3^{\circ}, 6^{\circ}, 9^{\circ}, 12^{\circ}$ e $15^{\circ}$ dias após a cirurgia, sacrificando-se 2 animais por vez.

Foram notadas algumas falhas:

$\checkmark \quad$ surgiu a dúvida de como a cicatrização ocorreria se fosse aplicado o creme sem colágeno;

$\checkmark \quad$ as lesões de $10 \mathrm{~mm}^{2}$ cicatrizaram muito rápido, quase não sendo possível estender o tratamento até o $10^{\circ}$ dia;

$\checkmark \quad$ a membrana apresentou aspecto ressecado, e o manuseio para contenção dos animais provocava o descolamento da mesma.

\section{III.5.2. Piloto II}

Realizamos outro experimento com 10 ratos na tentativa de adequar 0 protocolo à fisiologia dos animais e à realização do estudo. O grupo controle foi dividido em duas partes, onde metade recebeu tratamento tópico simples, ou seja, limpeza com solução fisiológica, e a outra metade recebeu tratamento com o creme hidratante sem colágeno. O grupo tratado recebeu os mesmos tratamentos propostos: aplicação do creme contendo colágeno e a sutura da membrana de serosa porcina. O tamanho da lesão foi padronizado em $20 \times 20 \mathrm{~mm}$ e, desta vez, foram estabelecidos 9 dias para tratamento, com coleta de material nos $3^{\circ}, 5^{\circ}, 7^{\circ} \mathrm{e}$ $9^{\circ}$ dias após a cirurgia, sacrificando-se 2 animais por vez. 
$\mathrm{Na}$ tentativa de se evitar o ressecamento da membrana de colágeno pela exposição, foram feitos curativos oclusivos com gaze embebida em solução fisiológica envolta por atadura elástica auto-adesiva (3 M). Pelo fato desta apresentar grandes poros, aproveitamos para rehidratar as gazes sem que fosse necessário remover as ataduras. Infelizmente, a maioria dos animais acabou, cedo ou tarde, por arrancar as ataduras e as membranas acabavam por secar da mesma maneira, com um agravante: algumas gazes aderiam às membranas $e$, quando manipuladas, acabavam por tracioná-las provocando seu descolamento.

\section{III.5.3. Procedimento final com ratos}

Após os testes preliminares realizados para que o protocolo de tratamento fosse otimizado, o trabalho definitivo foi realizado com 44 ratos machos que foram submetidos à excisão cirúrgica de um "flap" de pele de $20 \times 20 \mathrm{~mm}$, criando-se 88 feridas planas divididas em igual número para os 4 grupos (Figura 12).

O grupo de controle foi dividido, sendo que metade recebeu tratamento tópico simples, ou seja, limpeza com solução fisiológica (controle 1), e a outra metade recebeu tratamento com o creme hidratante $\left(\right.$ Merck $\left.^{\circledR}\right)$ sem colágeno (controle 2).

As lesões do lado direito receberam os tratamentos em estudo, onde metade foi tratada com o creme contendo colágeno e a outra metade, com sutura da membrana de serosa porcina.

Os animais foram submetidos à eutanásia para coleta de material nos $3^{\circ}$, $5^{\circ}, 7^{\circ}$ e $9^{\circ}$ dias pós-cirurgia. As amostras foram colhidas com uma lâmina de bisturi pela retirada de um fragmento de pele tendo como limites de um dos lados a pele íntegra e, de outro, o centro da lesão. 

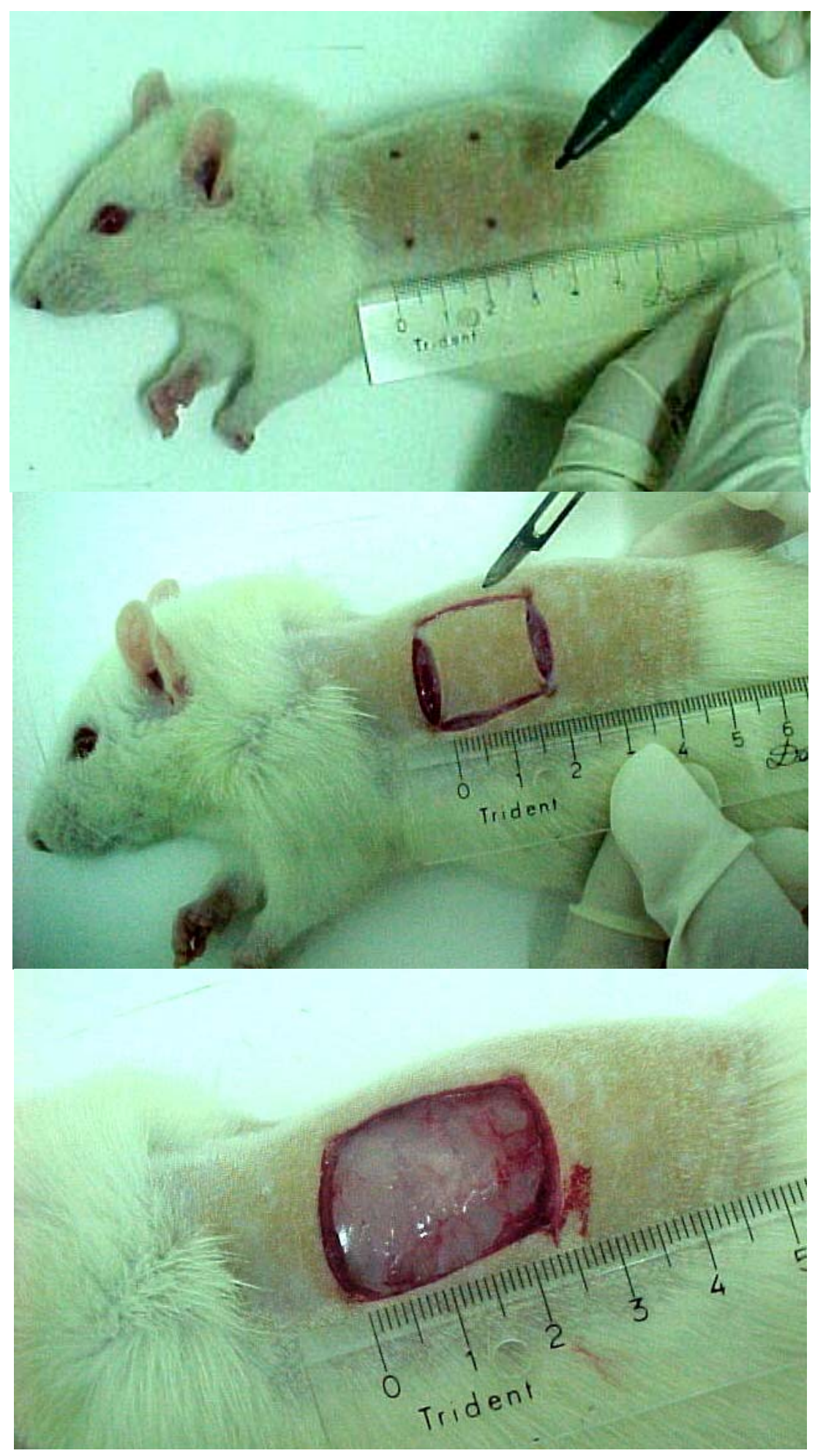

Figura 12 - Fotos digitais da marcação (superior), excisão do "flap" (centro) e aspecto da ferida plana (abaixo). 


\section{III.6 Histologia}

A maior parte dos tecidos não pode ser observada in vivo. Devido a esse fato, eles devem ser submetidos a processos de fixação para que suas estruturas morfológicas mantenham-se preservadas. Os processos descritos abaixo irão originar lâminas duradouras (Figura 13).

\section{III.6.1. Fixação}

A degeneração post-mortem é o conjunto de autólise celular e ação de microorganismos decompositores. Para evitar a degeneração empregam-se substâncias para que, ao se ligarem aos principais componentes estruturais do tecido (geralmente proteínas), mantenham a estrutura do material a ser estudado. O processo de preservação dos componentes estruturais dos tecidos denomina-se fixação. As substâncias que executam o processo de fixação são chamadas fixadores. O mecanismo de ação dos fixadores é pouco conhecido e todos possuem vantagens e desvantagens.

Os cientistas desenvolveram misturas empíricas de fixadores para compensar suas principais desvantagens. Os principais fixadores são: formol (utilizado neste trabalho na concentração de 10\%); líquido de Bouin; líquido de Helly; aldeído glutárico; tetróxido de ósmio. 

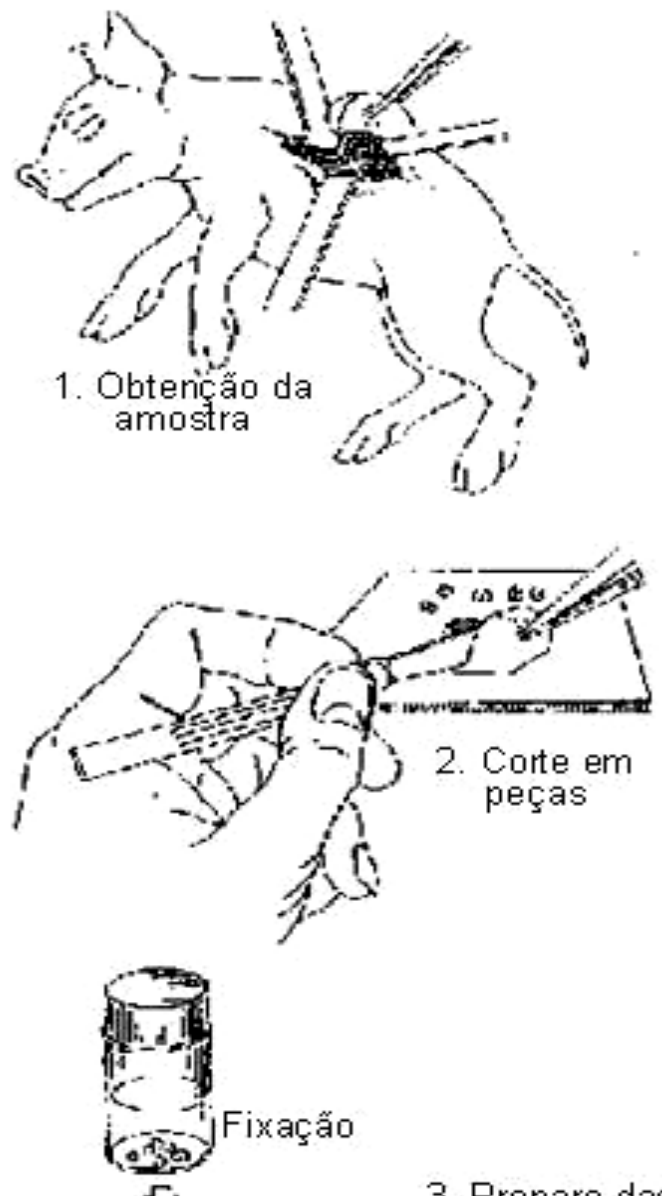

ᄃ.

Desidrataçẫo

$$
5 .
$$

Diafanizaçã̃o 13

Inclusẫo em parafina
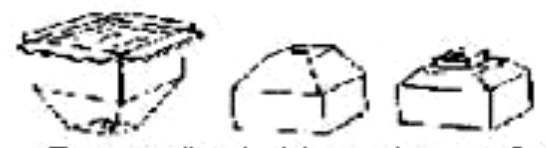

Formaçẫo do bloco de parafina

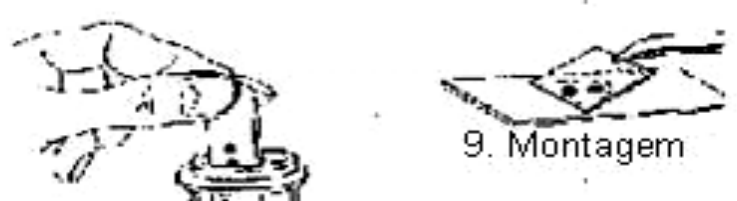

8. Coloraçẫo

7. Secagem em mesa termica

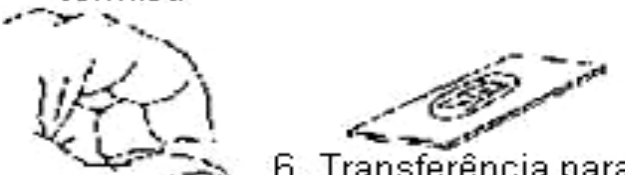

6. Transferência para a lâmina

5. Extensẫo dos cortes em banho-maria

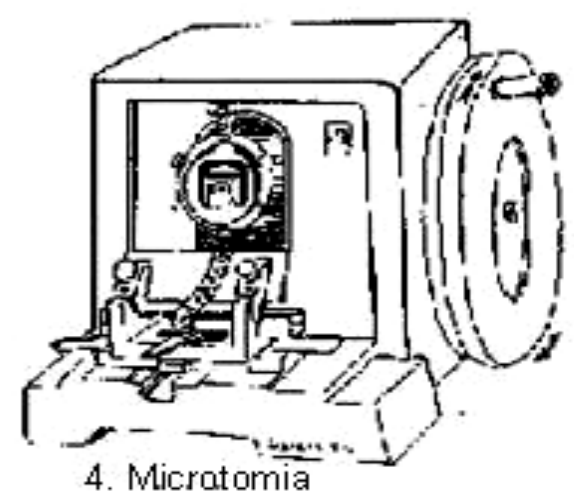

Figura 13 - Técnica histológica para preparação de lâminas (VASCONCELOS, 2005). 


\section{III.6.2. Desidratação}

A desidratação das peças é um processo necessário para que possam ser incluídas em parafina. É necessário que se faça uma substituição gradual com imersão em soluções de álcool com concentrações crescentes (álcool 70\%, 90\%, $95 \%, 100 \%$ I, $100 \%$ II e 100\% III) permanecendo 1 hora em cada recipiente para completa remoção da água. Porém, álcool e parafina não são miscíveis, havendo a necessidade de substituir o álcool por xilol.

\section{III.6.3. Diafanização}

O xilol é um agente diafanizador (solvente de parafina). Desta maneira, a peça é imersa em xilol com concentrações crescentes (álcool-xilol, xilol I, II e III) permanecendo 1 hora em cada recipiente a fim de promover a total substituição do álcool.

\section{III.6.4. Inclusão}

A fim de que os tecidos suportem o processo de corte, eles devem ser impregnados com parafina ou resinas epóxi (caso o corte seja mais delgado, como utilizado em microscopia eletrônica). Esse processo chama-se impregnação ou inclusão.

A inclusão é feita colocando-se as peças em banhos de parafina, para que o xilol seja totalmente substituído pela mesma. Em geral, a parafina apresenta ponto de fusão oscilando entre 40 e $65^{\circ} \mathrm{C}$ e ferve a $300^{\circ} \mathrm{C}$. A mais indicada para o trabalho de Histologia (inclusão em geral) é a com ponto de fusão entre 50 e $55^{\circ} \mathrm{C}$. Os trabalhos de inclusão podem ser divididos em 3 etapas: embebição, inclusão definitiva ou formação do bloco, toalete do bloco e sua fixação no suporte. Para este trabalho seguimos os seguintes procedimentos:

$\mathrm{Na}$ embebição a peça diafanizada foi passada por 3 banhos de parafina líquida (banhos I, II e III), mantida em estufa a $60^{\circ} \mathrm{C}$ (esta temperatura não deve 
ser ultrapassada para que o material não seja danificado); em cada banho a permanência foi de 1 a 1 hora e meia. Após o $1^{\circ}$ banho, o processo de embebição pode ser interrompido por até 24 horas. Para tanto, basta retirar da estufa a vasilha contendo a peça. Prosseguindo o trabalho, a vasilha volta para a estufa e, quando a parafina estiver novamente fundida, continua-se com a seqüência de banhos.

Para inclusão definitiva do material em parafina, formando um bloco, são utilizadas pequenas caixas de papel construídas com um molde de madeira (o mesmo bloco suporte do micrótomo). A parafina líquida $\left(60-65^{\circ} \mathrm{C}\right)$ foi colocada na caixa, evitando que se formassem muitas bolhas de ar; tal procedimento deve ser rápido para que a parafina não se solidifique. Em seguida, utilizando uma pinça aquecida, as peças eram cuidadosamente acomodadas em meio à parafina, procurando orientá-las no sentido da superfície a ser cortada (lado inferior do molde). Assim que a parafina se apresente superficialmente endurecida, o bloco deve ser levado a um recipiente com água, para que ocorra um resfriamento rápido, de modo que fique homogêneo. A solidificação normalmente se completa em torno de 30 minutos.

Depois os blocos são retirados das caixas para que o toalete e sua fixação no suporte de madeira possam ser feitos. Com auxílio de um bisturi, o excesso de parafina dos lados da peça é removido, de modo que permaneça apenas uma camada de 2 a $3 \mathrm{~mm}$ envolvendo o material. O bloco de parafina deve ser talhado num formato retangular ou piramidal, onde a base é colada ao bloco de madeira (suporte) com auxílio de uma espátula metálica aquecida que liquefaz a parafina. Com uma lâmina é feito o talhado definitivo do bloco: sua altura não deve ultrapassar de 10 a $15 \mathrm{~mm}$, a camada de parafina na superfície a ser cortada deve ficar limitada a 1 ou $2 \mathrm{~mm}$, e as bordas devem estar paralelas entre si. 


\section{III.6.5. Microtomia e Montagem dos Cortes sobre as Lâminas}

Para que os componentes do tecido possam ser visualizados, a luz deve atravessá-los, dirigindo-se aos olhos do observador. Isto limita a espessura dos cortes a poucos micrômetros. Os cortes desse estudo foram feitos com uma espessura de 7 micras.

Lâminas limpas devem receber uma fina camada de albumina-glicerina (misturadas em partes iguais) para garantir a colagem dos cortes, e devem estar secas antes de receberem as fitas. Quando os cortes são feitos no micrótomo a parafina e o material envolto por ela sofrem enrugamento. Devemos, então, providenciar para que fique distendida (não derretida) colocando pouca água sobre a lâmina e esta sobre uma placa aquecida $\left(50^{\circ} \mathrm{C}\right)$. Após o resfriamento, escorre-se o excesso de água, se necessário faz-se uso de papel de filtro. Com auxílio de um pincel, posiciona-se o corte sobre a lâmina, levando depois para secagem em estufa $\left(40^{\circ} \mathrm{C}\right)$, de 15 a 30 minutos. Os cortes podem permanecer até por um dia na estufa se a temperatura for de $37^{\circ} \mathrm{C}$.

Filtrar (a filtração demora alguns dias) e adicionar um pouco de cânfora ou salicilato de sódio para evitar o desenvolvimento de fungos.

\section{III.6.6. Coloração}

Como a maioria dos corantes age somente em solução aquosa, para que se possa corar, deve-se promover a hidratação dos cortes (desparafinização, eliminação do solvente e hidratação), seguindo o procedimento descrito abaixo:

- xilol III 5 minutos

- xilol II 5 minutos

- xilol I 5 minutos

- $\quad$ xilol: álcool 2:1 5 minutos

- xilol: álcool 1:1 5 minutos

- xilol: álcool 1:2 5 minutos 
- álcool $100 \%$ III 3 minutos

- álcool 100\% II ...................................................3 minutos

- álcool 100\% I .................................................... 3 minutos

- álcool 95\% ........................................................ minutos

- álcool 90\% ...................................................... minutos

- álcool $70 \%$................................................. minutos

- água destilada ............................................enxaguar

Todos os passos devem ser feitos com cuidado, evitando o deslocamento dos cortes. Os álcoois e xilóis utilizados devem ser reaproveitados. Após a passagem por água destilada as lâminas estão prontas para serem coradas, conforme o método de escolha.

\section{III.6.6.1. Corantes}

Os corantes são compostos químicos com determinados radicais ácidos ou básicos que possuem cor, e apresentam afinidade de combinação com estruturas básicas ou ácidas dos tecidos. Rotineiramente, usa-se hematoxilina, corante básico que se liga aos radicais ácidos dos tecidos, e eosina, corante ácido que tem afinidade por radicais básicos dos tecidos. Os componentes que se combinam com corantes ácidos são chamados acidófilos e os componentes que se combinam com corantes básicos são chamados basófilos. Por exemplo, os núcleos das células, onde predominam substâncias ácidas (DNA), são basófilos, ou seja, coram-se pela hematoxilina (corante básico de cor roxa); por sua vez, o citoplasma, onde predominam substâncias básicas (proteínas estruturais), é acidófilo, corando-se pela eosina (corante ácido de cor rosa). Neste trabalho, pela necessidade de se avaliar a presença das fibras de colágeno optou-se por, além de HE, utilizar a coloração de Tricrômio de Mallory. 
A preparação do corante Hematoxilina-Eosina (HE) foi feita como descrito a seguir:

a) Hematoxilina (corante básico)

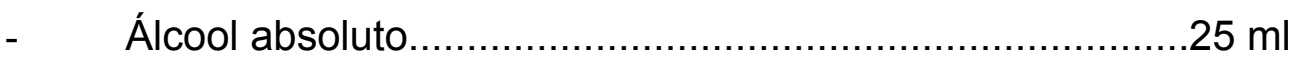

- Hematoxilina cristalizada......................................... $\mathrm{g}$

- $\quad$ Sulfato de alumínio (solução saturada)......................400 ml

Dissolver bem os cristais de hematoxilina no álcool e juntar o sulfato de alumínio. Deixar exposta à luz, em frasco aberto, agitando algumas vezes. Depois filtrar e adicionar:

Álcool metílico.....................................................100 ml

- Glicerina.....................................................100 ml

Deixar em um frasco aberto durante 4 semanas. Depois filtrar e guardar em frasco bem fechado. Embora este corante conserve-se por muito tempo, pode-se diluí-lo em solução de alúmen a $2 \%$, na proporção de 1:1 quando estiver envelhecido.

b) Eosina (corante ácido)

- Álcool 90\%.......................................................100 ml

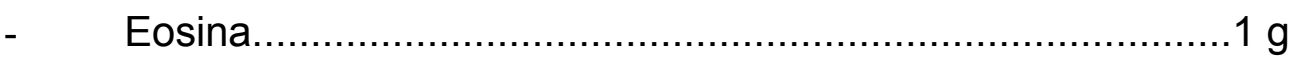

\section{III.6.6.2. Método de Coloração com HE}

1) Utilizando uma cuba própria para acomodar as lâminas (ou diretamente sobre as mesmas), corar de 3 a 5 minutos com hematoxilina. Controlar ao microscópio a coloração; se estiver excessiva, diferenciar em álcool acetificado.

2) Lavar durante um minuto em água corrente.

3) Corar durante 15 minutos com eosina.

4) Lavar durante 1 minuto em água corrente. 
5) Diferenciar a eosina em álcool $70 \%$, passando rapidamente a lâmina pelo álcool.

6) Promover a desidratação, seguindo o procedimento citado, para que as lâminas possam ser montadas em Bálsamo do Canadá.

III.6.6.3. Método de coloração com Mallory (A preparação do corante está descrita na Tabela 1)

1. Utilizando uma cuba própria para acomodar as lâminas (ou diretamente sobre as mesmas), corar 3 minutos com Fucsina.

2. Lavar em água acetificada (água com gotas de ácido acético), fazendo de 3 a 5 imersões.

3. Diferenciar o tecido conjuntivo com ácido fosfomolíbdico a $1 \%$, durante 1 minuto (controlar ao microscópio, até que a coloração vermelha desapareça).

4. Lavar em água acetificada.

5. Corar por, pelo menos, 20 minutos com azul de anilina-orange $\mathrm{G}$.

6. Lavar em água acetificada (3 imersões).

7. Desidratar e montar em Bálsamo de Canadá. 
Tabela 1 - Preparação do Tricrômio de Mallory.

\begin{tabular}{|c|c|c|}
\hline CORANTE & ÍTEM & QUANTIDADE \\
\hline \multirow{2}{*}{ 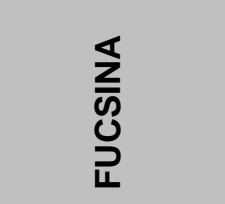 } & FUCSINA ÁCIDA & $0,5 \mathrm{~g}$ \\
\hline & ÁGUA DESTILADA & $100 \mathrm{~mL}$ \\
\hline \multirow{4}{*}{ 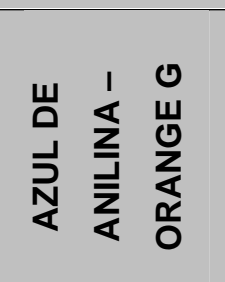 } & AZUL DE ANILINA & $0,5 \mathrm{~g}$ \\
\hline & ORANGE G & $2 g$ \\
\hline & ÁCIDO OXÁLICO & $2 \mathrm{~g}$ \\
\hline & ÁGUA DESTILADA & $100 \mathrm{~mL}$ \\
\hline
\end{tabular}

\section{III.6.6.4. Montagem das Lâminas em Bálsamo do Canadá}

Após serem coradas, quando os corantes utilizados forem soluções aquosas, a fim de permitir perfeita visualização dos tecidos, as lâminas devem ser desidratadas para prevenir a difusão dos corantes e porque a água possui índice de refração diferente do vidro podendo prejudicar a leitura. Outra vez procedeu-se com a diafanização com xilol, a fim de tornar os cortes perfeitamente transparentes.

Desidratação:

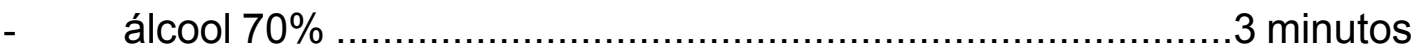

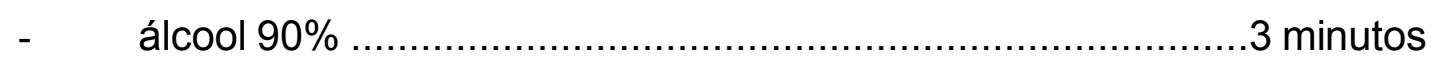

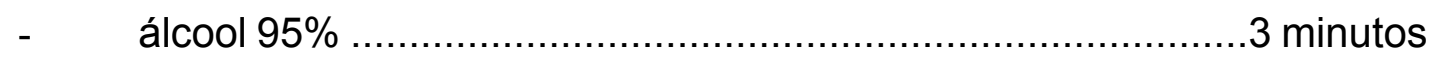

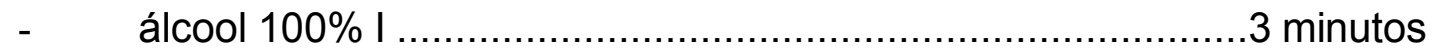

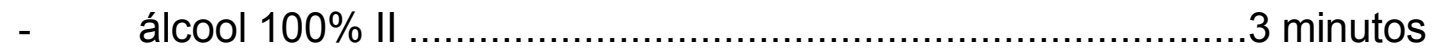

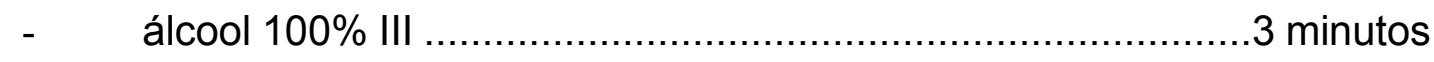

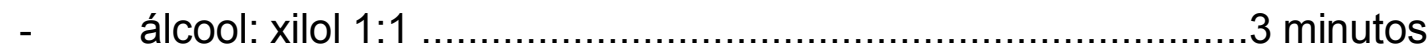

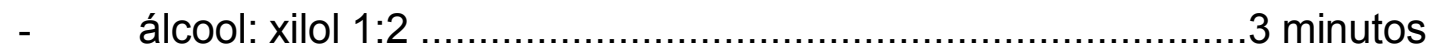

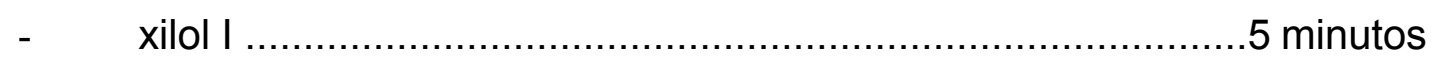

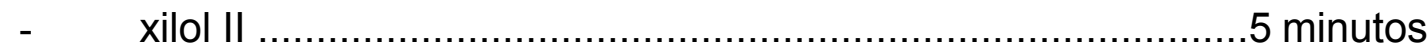

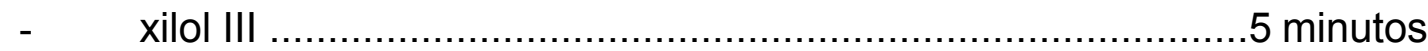


Foi feita, então, a montagem que é a etapa final da técnica histológica, e consiste na colagem da lamínula sobre o corte, com bálsamo do Canadá, uma resina que é solúvel em xilol e insolúvel em água. A lamínula impede que haja hidratação do corte pela umidade do ar ambiente, permitindo então que estas lâminas se mantenham estáveis por tempo indefinido. Os álcoois e xilóis usados no processo de desidratação não devem ser os mesmos utilizados anteriormente na desparafinização e hidratação. Saindo do xilol III, as lâminas foram imediatamente para a montagem, para que não ocorresse a secagem do xilol. Foi colocada uma gota do Bálsamo sobre o material e, em seguida, a lamínula, procurando evitar a formação de bolhas de ar. Depois foram levadas para estufa na posição horizontal, onde permaneceram por pelo menos por 48 horas $\left(36^{\circ} \mathrm{C}\right)$ para a secagem do Bálsamo. Assim, as lâminas estavam prontas para etiquetagem e leitura.

A preparação das lâminas foi feita no Laboratório de Histologia do Departamento de Hidrobiologia da Universidade Federal de São Carlos (UFSCAR) sob a orientação da Professora Doutora Nelcy Fenerich Verani. 


\section{RESULTADOS E DISCUSSÕES}

\section{IV.1. Creme com colágeno}

Após familiarização com a técnica de espatulação, a mistura do creme com o gel de colágeno foi bastante simples, demorando em torno de 10 (dez) minutos até que os grumos do gel se desfizessem uniformemente em meio ao creme. Aparentemente, o aspecto deste (cor e consistência) não sofreu alteração após a mistura.

\section{IV.2. Reologia do creme}

Os resultados mostraram que a viscosidade do creme diminui cerca de $10 \%$ após a adição do colágeno. Aos 70 dias de armazenamento não se observa alteração na viscosidade para a amostra mantida na temperatura ambiente e um aumento de cerca de $20 \%$ para a amostra conservada em geladeira (Figura 14 e Figura 15). O comportamento elástico do creme pode ser observado pelos valores da tangente de perda ( $\tan \delta$ ) que é a razão entre o módulo de perda (G”, que caracteriza o comportamento viscoso do material) e o módulo de armazenamento (G', que caracteriza o comportamento elástico). 


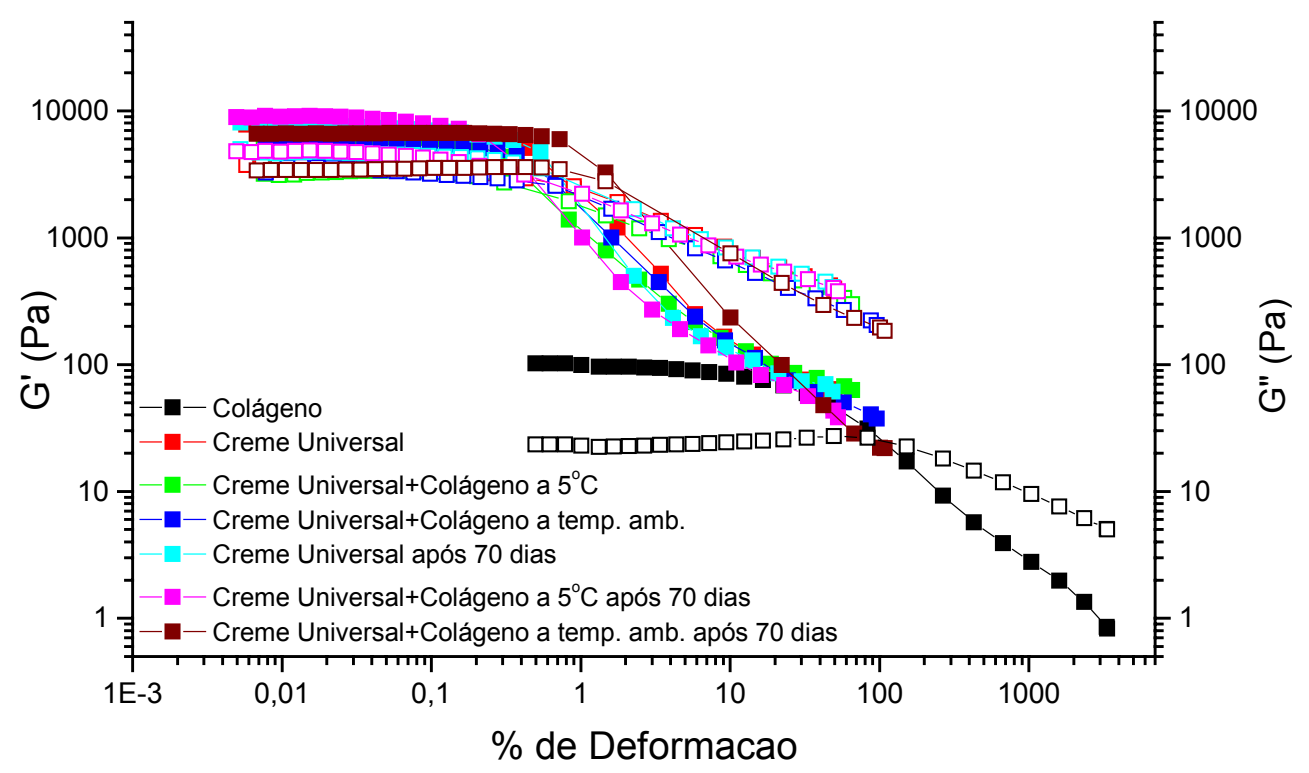

Figura 14 - Módulo Elástico e Viscoso em função da deformação para mistura creme universal: colágeno (90:10). — G'; G”.

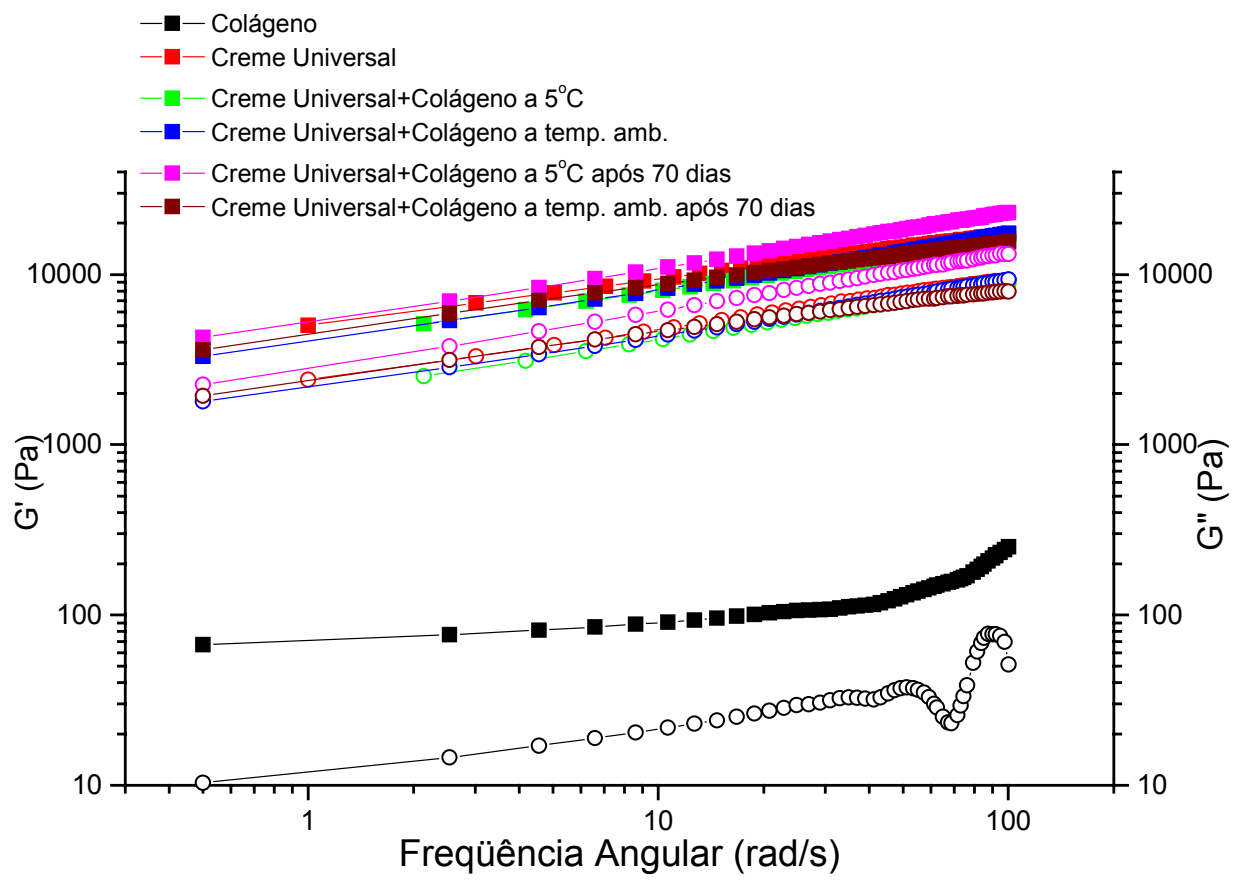

Figura 15 - Módulo Elástico e Viscoso em função da freqüência angular para mistura creme universal-colágeno (90:10). — G'; o G”. 
Os resultados mostram que as propriedades elásticas são predominantes, com extensa região viscoelástica linear, mostrando a habilidade das estruturas em resistir às tensões externas. Os valores de $\tan \delta$ obtidos na região linear são baixos $(\sim 0,5)$, não se alterando para a amostra mantida em geladeira (Figura 16). Para a amostra armazenada à $25^{\circ} \mathrm{C}$ durante 70 dias observou-se que embora a cor se mostrasse ligeiramente alterada, houve um decréscimo de apenas $3 \%$ no valor de $\tan \delta$, que o que mostra a estabilidade da formulação (Tabela 2).

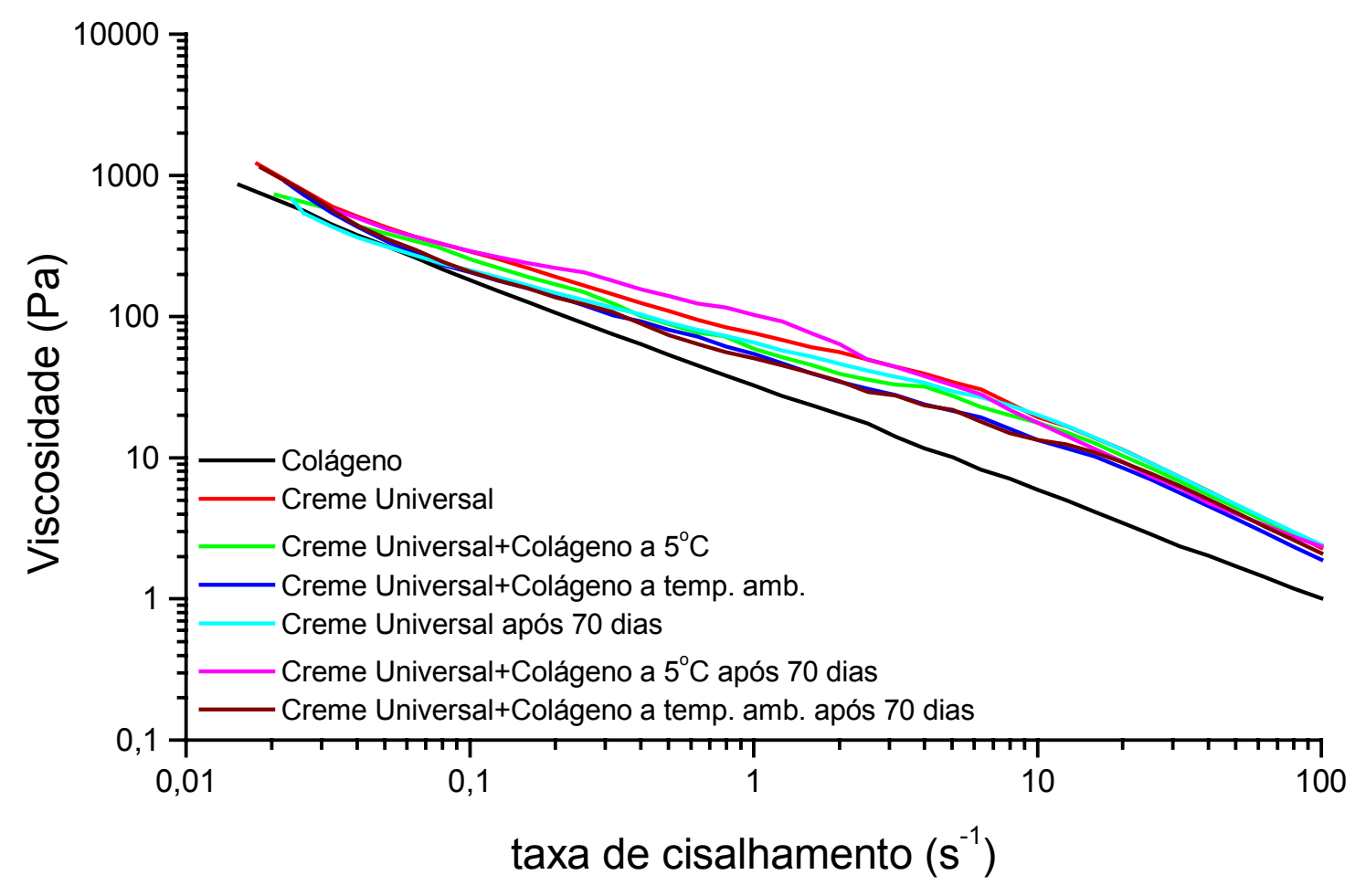

Figura 16 - Viscosidade em função da taxa de cisalhamento para mistura de creme:colágeno. 
Tabela 2 - Parâmetros Viscoelásticos para mistura creme:colágeno.

\begin{tabular}{|l|c|c|c|}
\hline \multicolumn{1}{|c|}{ Amostra } & G' & G' & Tan $\delta$ \\
\hline Colágeno & 102,4 & 23,5 & 0,23 \\
\hline Creme Universal & 7063 & 3460 & 0,49 \\
\hline Creme Universal após 70 dias & 7254 & 4526 & 0,62 \\
\hline Creme:Colágeno (Temperatura Ambiente) & 5892 & 3398 & 0,57 \\
\hline Creme:Colágeno a $5^{\circ} \mathrm{C}$ & 6207 & 3380 & 0,54 \\
\hline $\begin{array}{l}\text { Creme:Colágeno (Temperatura Ambiente) } \\
\text { após 70 dias }\end{array}$ & 6717 & 3496 & 0,52 \\
\hline Creme:Colágeno a $5^{\circ} \mathrm{C}$ após 70 dias & 8224 & 4406 & 0,53 \\
\hline
\end{tabular}

\section{IV.3. Membrana de colágeno}

\section{IV.3.1. Aspecto da membrana}

As imagens abaixo mostram fotos digitais da matriz colagênica antes do tratamento alcalino por 24h (Figura 17) e liofilização e o material final obtido após este tratamento (Figura 18).

Antes do tratamento, a matriz está na forma de um tubo cilíndrico que, ao ser cortado longitudinalmente, forma um tecido de 12 a $15 \mathrm{~cm}$ de largura. Apresenta uma coloração amarelada, algumas regiões com nervuras $(\sim 90 \mu \mathrm{m})$ e 
outras mais delgadas $(\sim 45 \mu \mathrm{m})$, boa flexibilidade, facilidade de manuseio (dobra, corte etc), assim como boa resistência à tração.

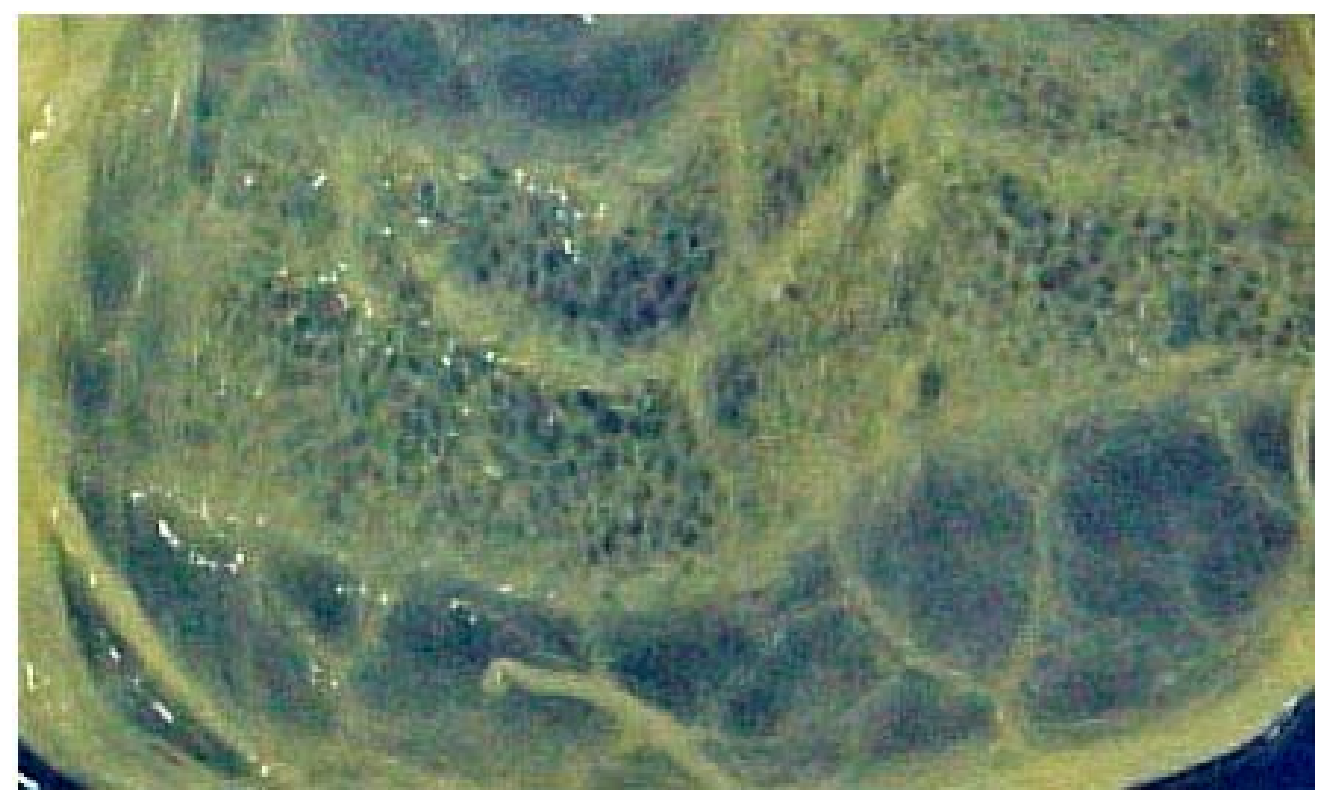

Figura 17 - Matriz colagênica antes do tratamento alcalino de 24 horas.

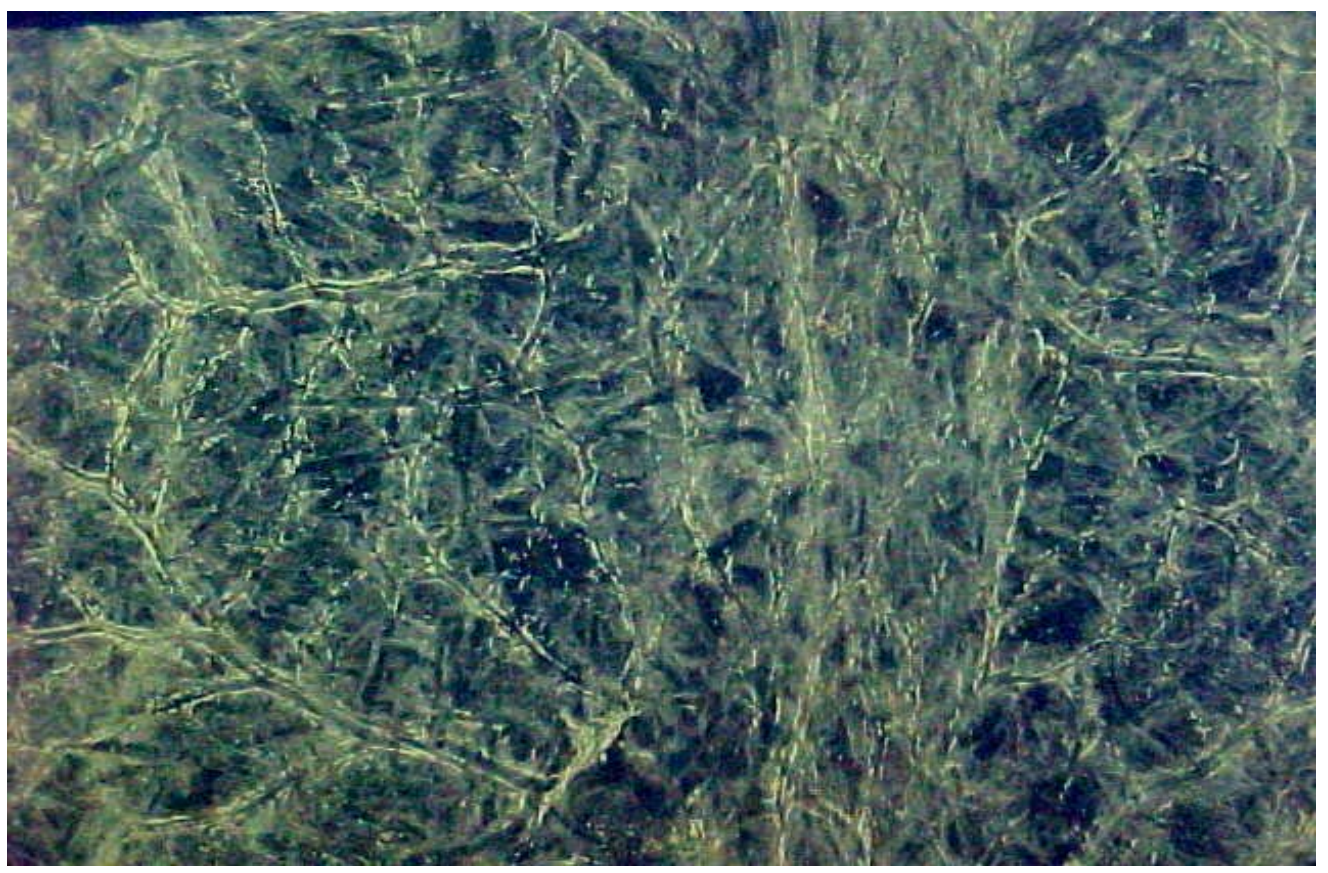

Figura 18 - Matriz colagênica depois do tratamento alcalino de 24 horas. 
Após o tratamento, as características da membrana não se alteram significativamente. A coloração torna-se esbraquiçada e a membrana fica mais delgada, com regiões quase transparentes. Possui um aspecto de folha de papel, permanece resistente e muito fácil de manusear. Ao ser colocada em água, ou solução salina, mantém sua forma sem enrolar ou rasgar (MENDES, 2003).

IV.3.2 Caracterização da membrana (MENDES, 2003)

\section{IV.3.2.1 Estabilidade Térmica}

Foi realizada a hidratação da matriz para uma melhor visualização da temperatura de desnaturação do colágeno, deixando mais evidente a temperatura de transição do material a $68^{\circ} \mathrm{C}$ (Figura 19), valor semelhante ao encontrado para pericárdio bovino (GIGLIOTI, 2005).

A estabilidade térmica do colágeno está diretamente relacionada à alteração de sua estrutura molecular, acarretando consideráveis mudanças em suas propriedades físicas em soluções, devido à destruição da estrutura tridimensional da tripla hélice de tropocolágeno ocorrendo, assim, a separação das três cadeias $\alpha$. $O$ aumento da temperatura, em certo momento, supera as interações que estabilizam a estrutura da tripla hélice, provocando a desnaturação e produzindo uma estrutura randômica conhecida como gelatina. Esta mudança ocorre abruptamente em uma temperatura, denominada de temperatura de desnaturação ( $(T d)$, que pode ser alterada por alguns fatores, como condições de solvente, $\mathrm{pH}$ e presença de sais (alteração da força iônica do meio). Os tipos e as quantidades de ligações de hidrogênio, em conjunto com as ligações cruzadas covalentes ou reticulações presentes nas microfibrilas, são responsáveis pelo aumento da temperatura de transição da estrutura do colágeno, por isto a análise térmica torna-se muito importante para o estudo de termo-estabilidade de tecidos ricos em colágeno. 

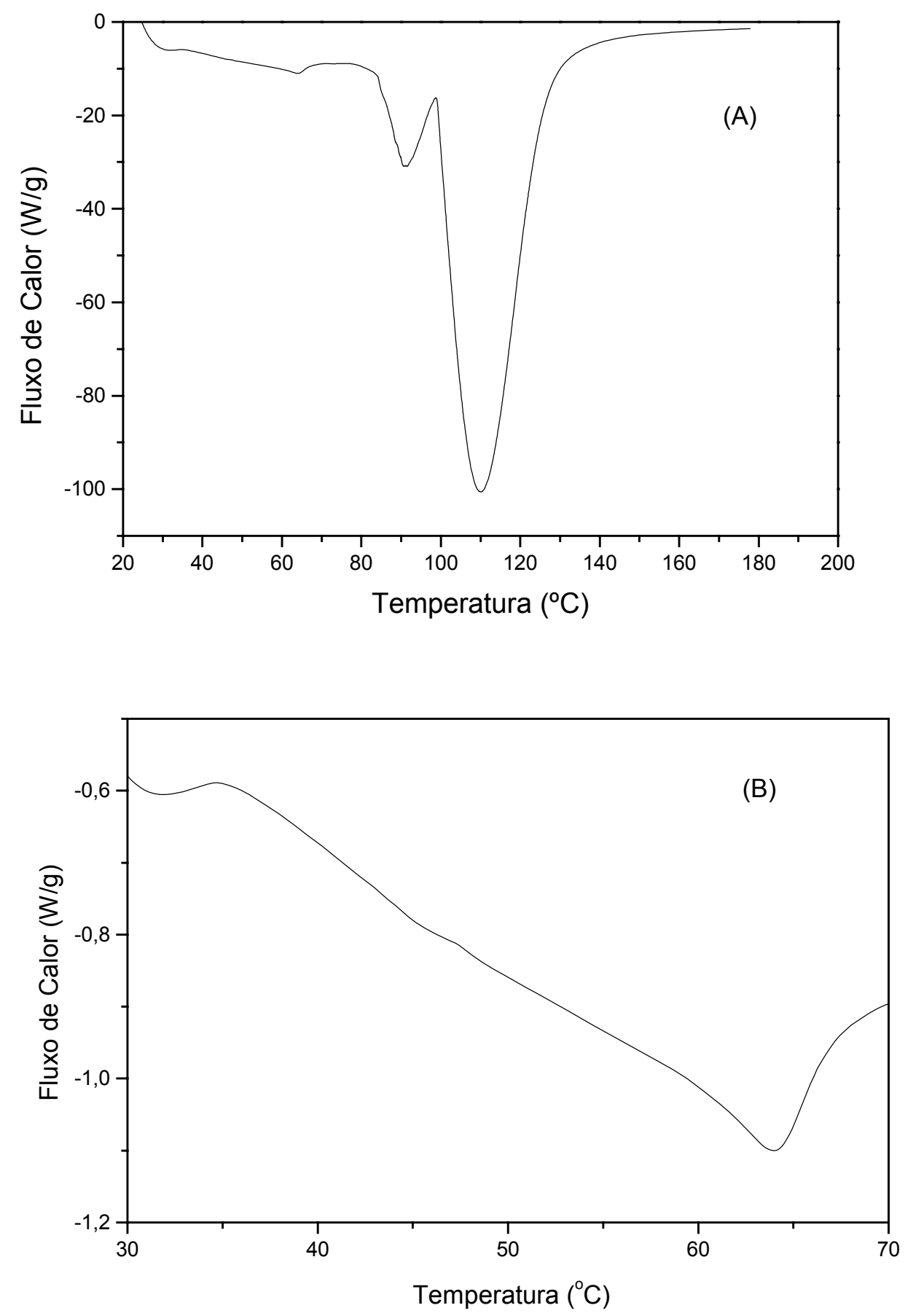

Figura 19 - (A): Curva DSC para matriz colagênica derivada de serosa hidratada obtida em $\mathrm{N}_{2}, 10^{\circ} \mathrm{C} \cdot \mathrm{min}^{-1}$; (B): escala expandida. 
A manutenção da estrutura secundária ( $\alpha$ hélice) da matriz colagênica é assim confirmada pelos resultados de DSC, visto que o colágeno quando desnaturado não apresenta nenhuma transição térmica no intervalo de temperatura estudado $\left(20-120^{\circ} \mathrm{C}\right)$.

\section{IV.3.2.2 Absorção de água}

A matriz absorve cerca de $65 \%$ de água em 15 min e observou-se que após 4h aproximadamente, atinge-se um equilíbrio (82\%) e a absorção não tem mudança significativa, demonstrando que há uma rápida saturação neste período.

\section{IV.3.2.3 Espectroscopia na Região do Infravermelho}

A análise por espectroscopia no infravermelho mostrou que a razão entre as absorbâncias em $1235 \mathrm{~cm}^{-1}$ e $1457 \mathrm{~cm}^{-1}$ é próxima de 1 , confirmando os dados de estabilidade térmica que mostraram a integridade da estrutura colagênica.

A espectroscopia na região do infravermelho é utilizada na confirmação da presença e da integridade do colágeno na matriz.

A Figura 20 e a Figura 21 mostram os espectros na região do infravermelho obtidos para uma membrana de colágeno (obtida por evaporação do solvente) e para a matriz colagênica obtida de serosa porcina, respectivamente. Nota-se uma grande semelhança entre os espectros. 


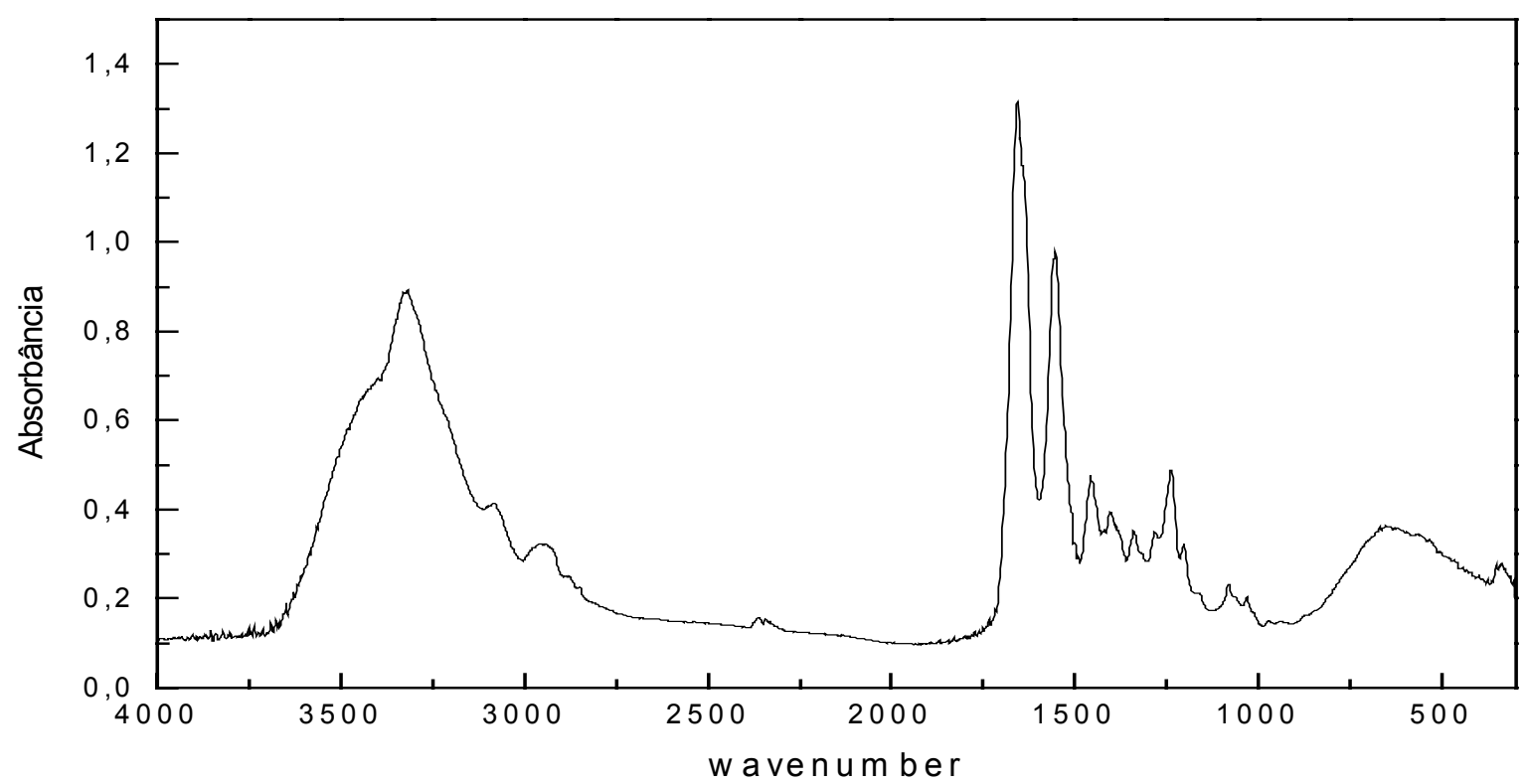

Figura 20 - Espectro na região do Infravermelho para colágeno tipo I obtido por solubilização de serosa porcina.

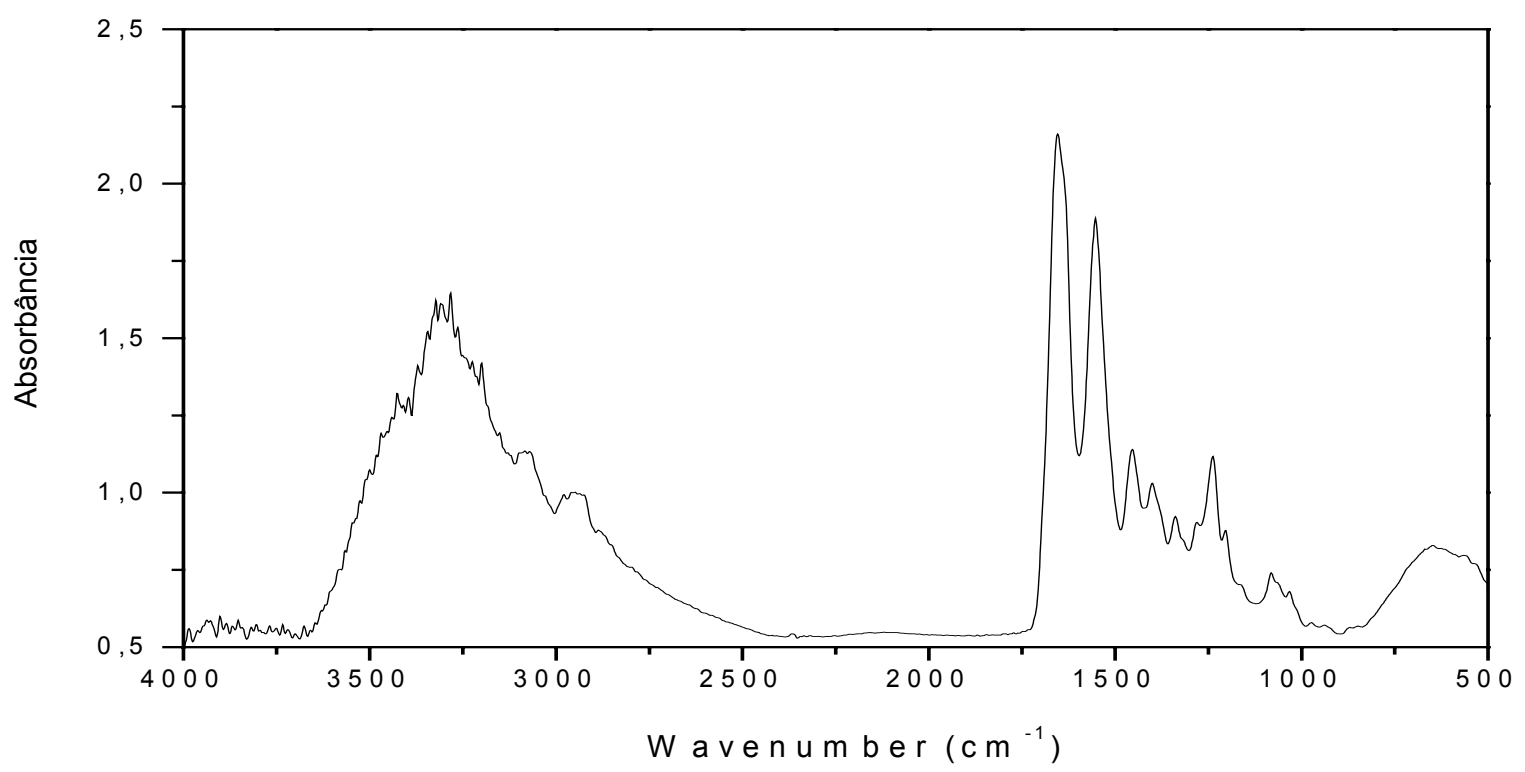

Figura 21 - Espectro na região do Infravermelho para matriz colagênica utilizada. 
A banda de amida III é muito sensível à presença da estrutura secundária do tropocolágeno, enquanto a banda $1450 \mathrm{~cm}^{-1}$ serve como padrão interno já que se mostra invariável em relação à ocorrência de desnaturação. Estas bandas correspondem às vibrações do tipo amida III (no plano), resultantes do estiramento $\mathrm{C}-\mathrm{N}$, da vibração $\mathrm{N}-\mathrm{H}$, da estereoquímica e ligações $\mathrm{C}-\mathrm{H}$ dos anéis pirrolidínicos de prolina e hidroxiprolina, respectivamente.

A integridade da estrutura secundária do colágeno pode ser verificada pela observação do valor da relação das absorbâncias em $1235 \mathrm{~cm}^{-1}$ e $1450 \mathrm{~cm}^{-1}$. $O$ valor encontrado para esta relação foi 0,98 , sensivelmente maior que o observado para estruturas desnaturadas, cujos valores estão por volta de 0,5 .

Isto implica em colágeno com baixo teor de gelatina, ou seja, com elevado conteúdo helicoidal, indicando que o processo de preparação da matriz não desnatura o colágeno.

\section{IV.3.2.4. Microscopia Eletrônica de Varredura (MEV)}

As micrografias mostram uma estrutura constituída de arranjos de fibras randomicamente dispostos, mas compactos em alguns pontos. As fibras não têm uma morfologia regular e parecem "fundidas" entre si nos locais mais compactos (Figura 22 e Figura 23). 


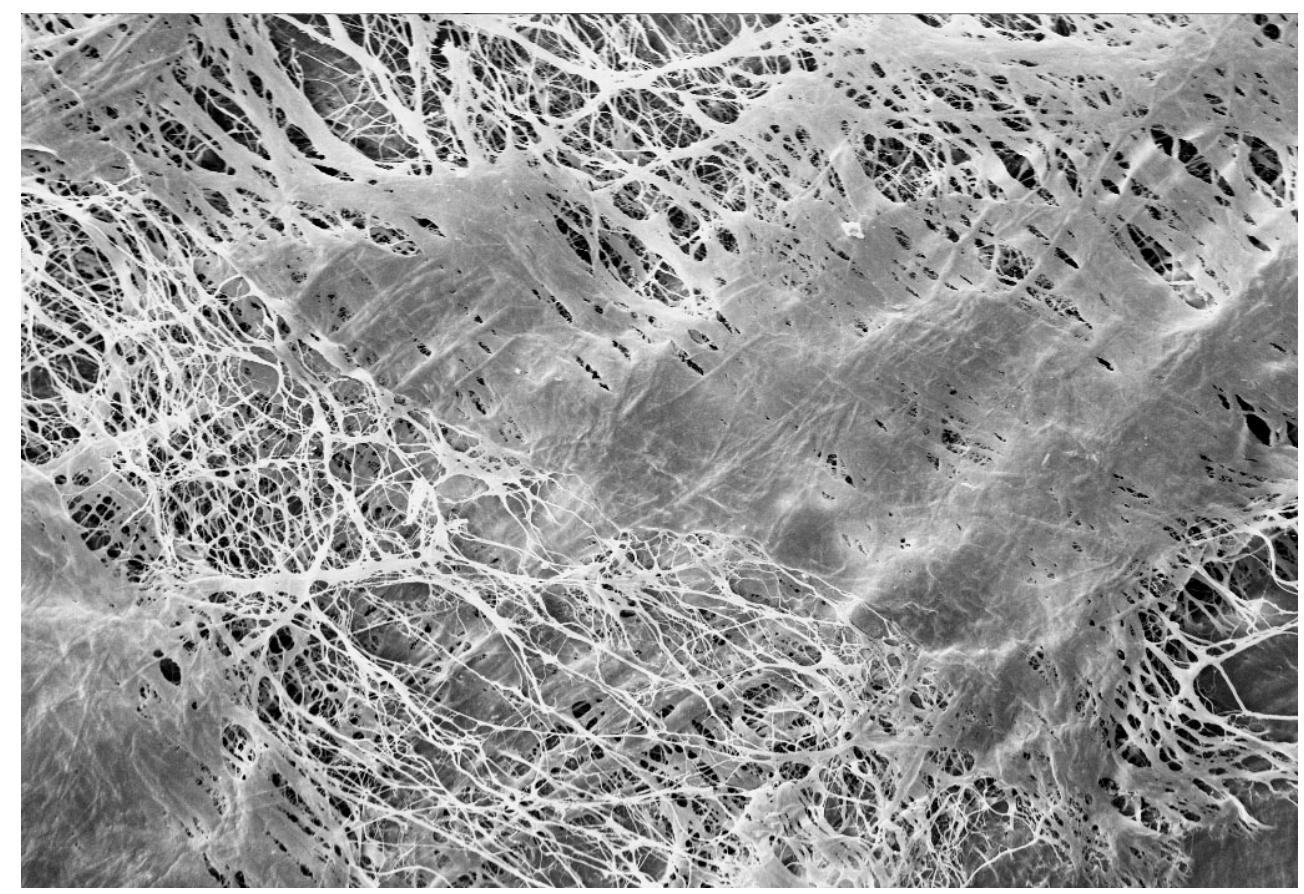

Figura 22 - MEV da superfície da matriz colagênica com aumento de 300X.

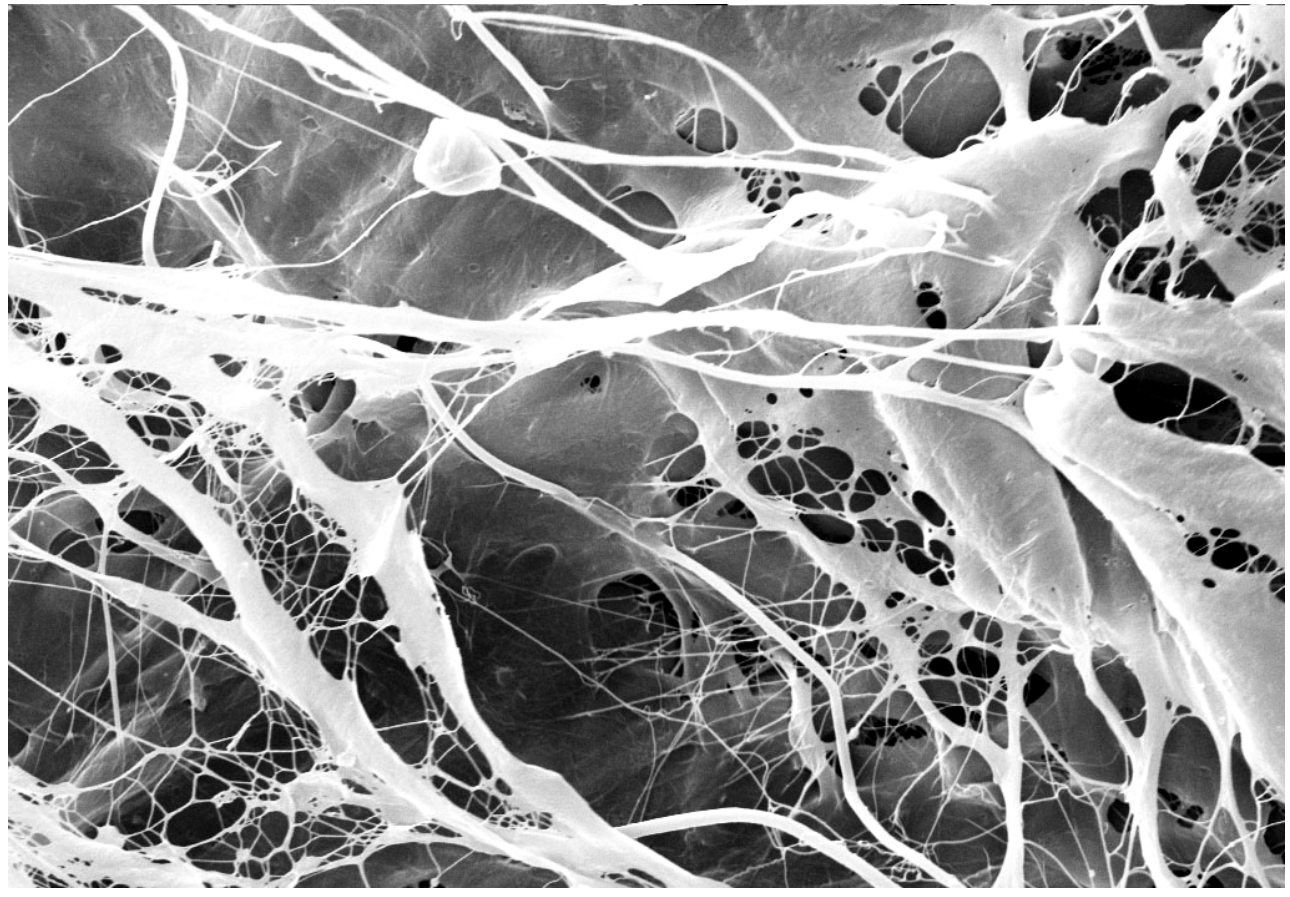

Figura 23 - MEV da superfície da matriz colagênica com aumento de 3500X. 


\section{IV.4. Procedimento in vivo}

Os animais receberam curativos diários, o que permitiu o acompanhamento macroscópico do processo de cicatrização das feridas. O creme, contendo ou não colágeno, foi de fácil aplicação; era espalhado e aderia sem dificuldades sobre o leito da lesão (Figura 24).

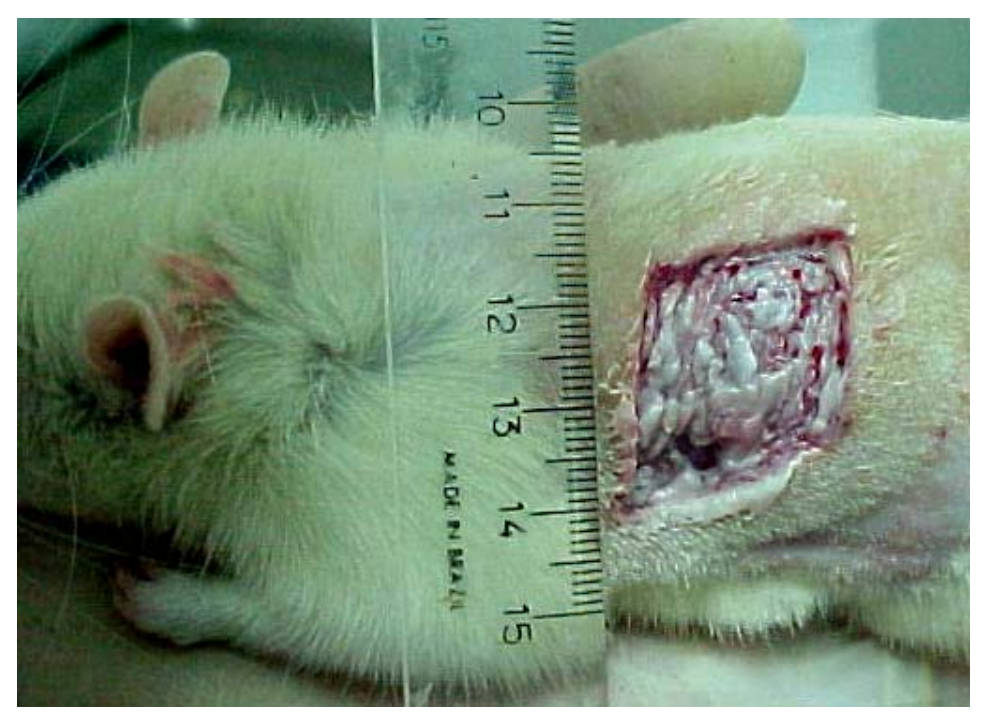

Figura 24 - Aspecto da ferida após receber tratamento com o creme.

A membrana demonstrou ser um material de manuseio fácil, com textura semelhante a papel de seda. Pôde ser cortada no tamanho escolhido para este experimento de $30 \times 30 \mathrm{~mm}$, de modo que houvesse sobra no momento de sua sutura às bordas da lesão. Mostrou ser bastante resistente à tensão dos pontos e não rasgou quando perfurada pela agulha trifacetada que acompanhava o fio mononylon 2-0 escolhido para o experimento (Figura 25). 


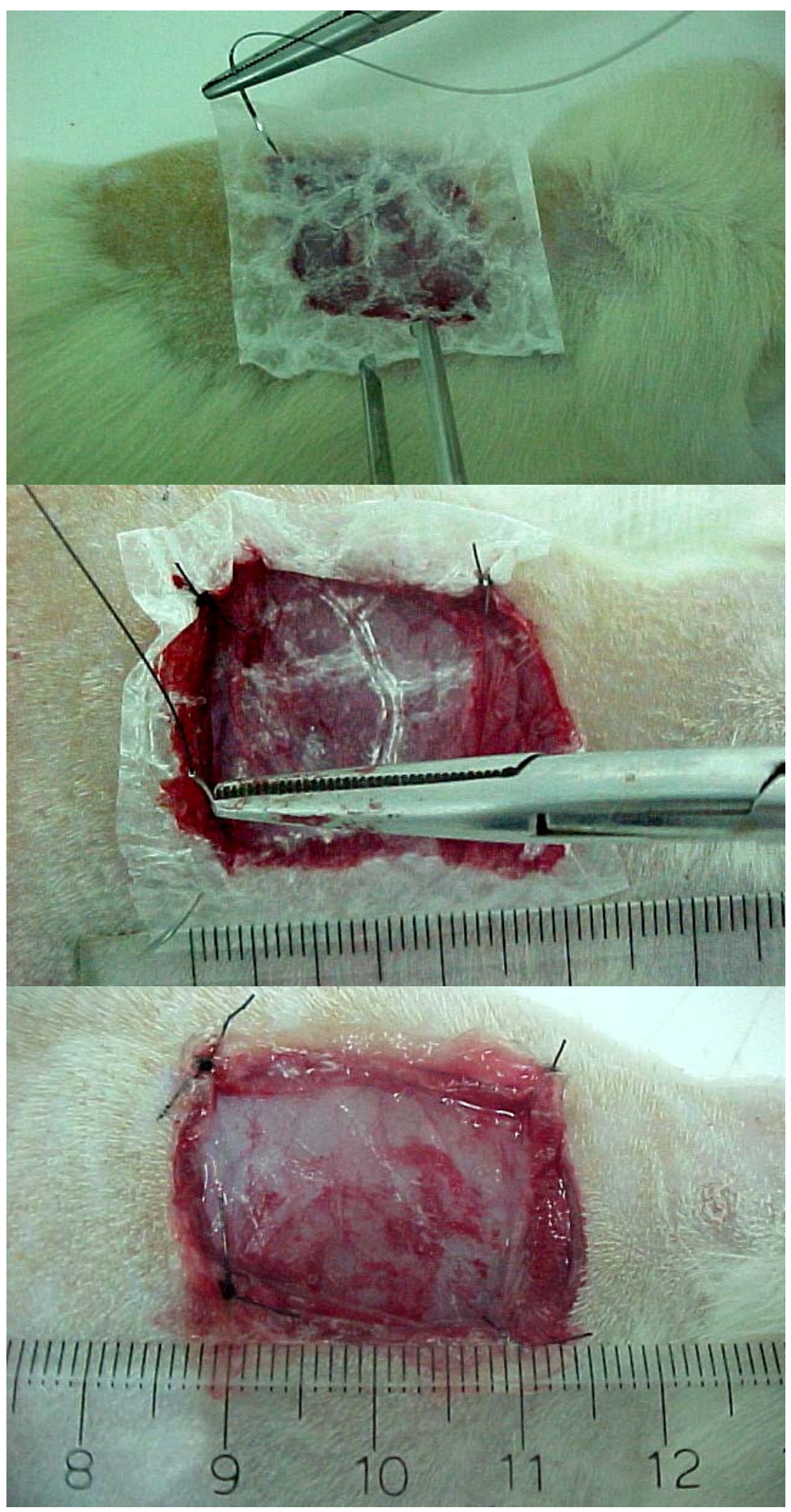

Figura 25 - Posicionamento da membrana (acima), sua sutura (centro) e seu aspecto imediatamente após fixação (abaixo). 
Em seguida ao contato com os líquidos corpóreos (exsudato e sangue), a membrana começava a absorvê-los, embebendo-se, tomando a aparência de um plástico transparente aderido à lesão.

No primeiro dia de curativos alguns ferimentos apresentavam pequenos fragmentos de serragem aderidos; os que não foram removidos após hidratação com solução fisiológica e suave contato com gaze, não foram retirados para evitar possível sangramento das lesões ainda recentes. As feridas não apresentavam exsudato, estavam róseas e limpas. As bordas excedentes de quase todas as membranas haviam desaparecido.

No segundo dia, após limpeza com o soro, as serragens que ainda permaneciam aderidas foram removidas cuidadosamente com uma pinça e não houve sangramento. As feridas, ainda recentes, estavam limpas e secas (sem presença de exsudato). As tratadas com os cremes (com e sem colágeno) pareciam mais viçosas (róseas e brilhantes) do que as tratadas com o soro. As feridas com membranas pareciam mais rasas e com área menor que as demais.

\section{IV.3.5.1. Terceiro dia}

Pouca diferença visual foi notada entre o tamanho das lesões tratadas com soro e as tratadas com os cremes (comparando-as entre si e com o tamanho das lesões no dia da cirurgia), exceto pelo aspecto do tecido lesionado que parecia com mais cor e brilho no caso das que receberam os cremes; todas apresentavam presença de fibrina (Figura 26). 

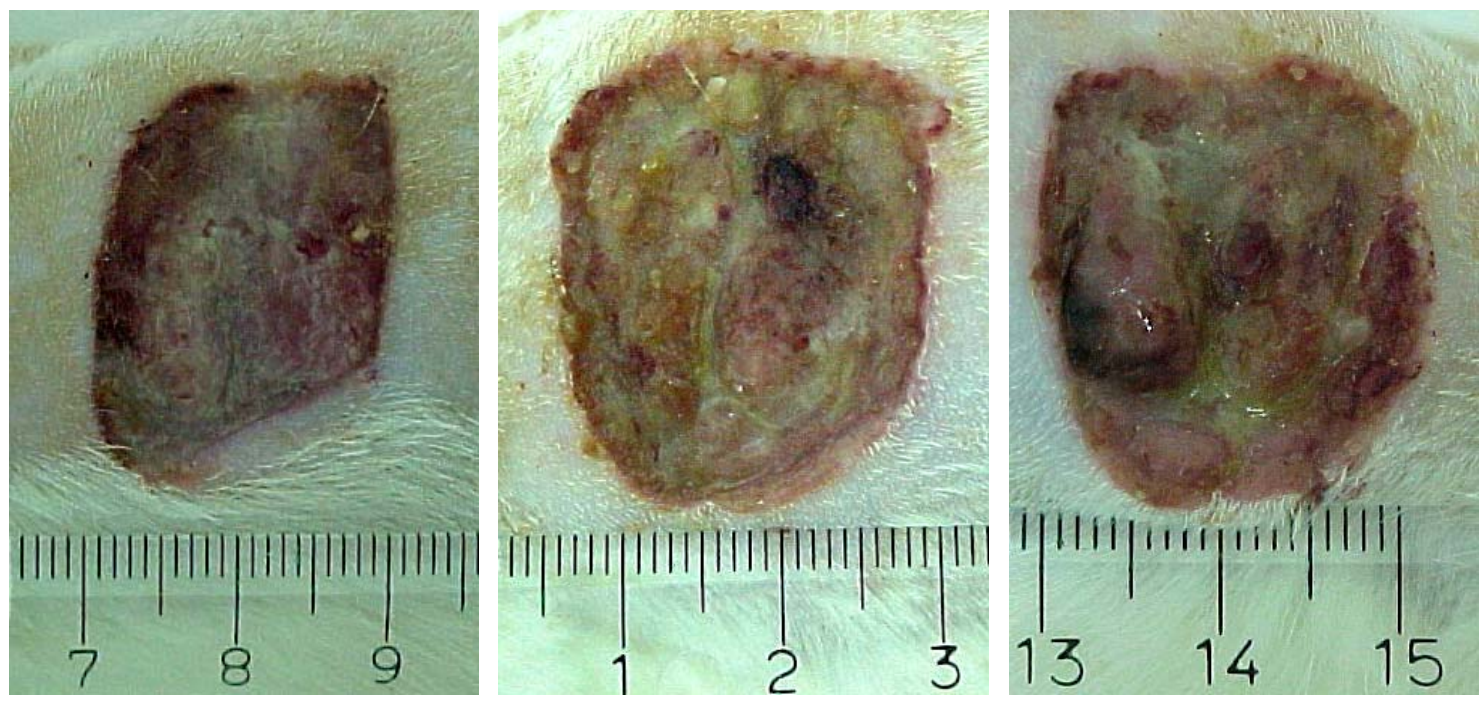

Figura 26 - Terceiro dia: soro (esq.), Merck ${ }^{\circledR}$ (centro) e creme-colágeno (dir.).

As feridas com membranas pareciam ainda mais retraídas (cerca de $40 \%$ menores nas aferições pela régua); estas apresentavam ressecamento e estavam mais escuras, assumindo uma tonalidade castanha; pareciam aderidas ao tecido subjacente (Figura 27).
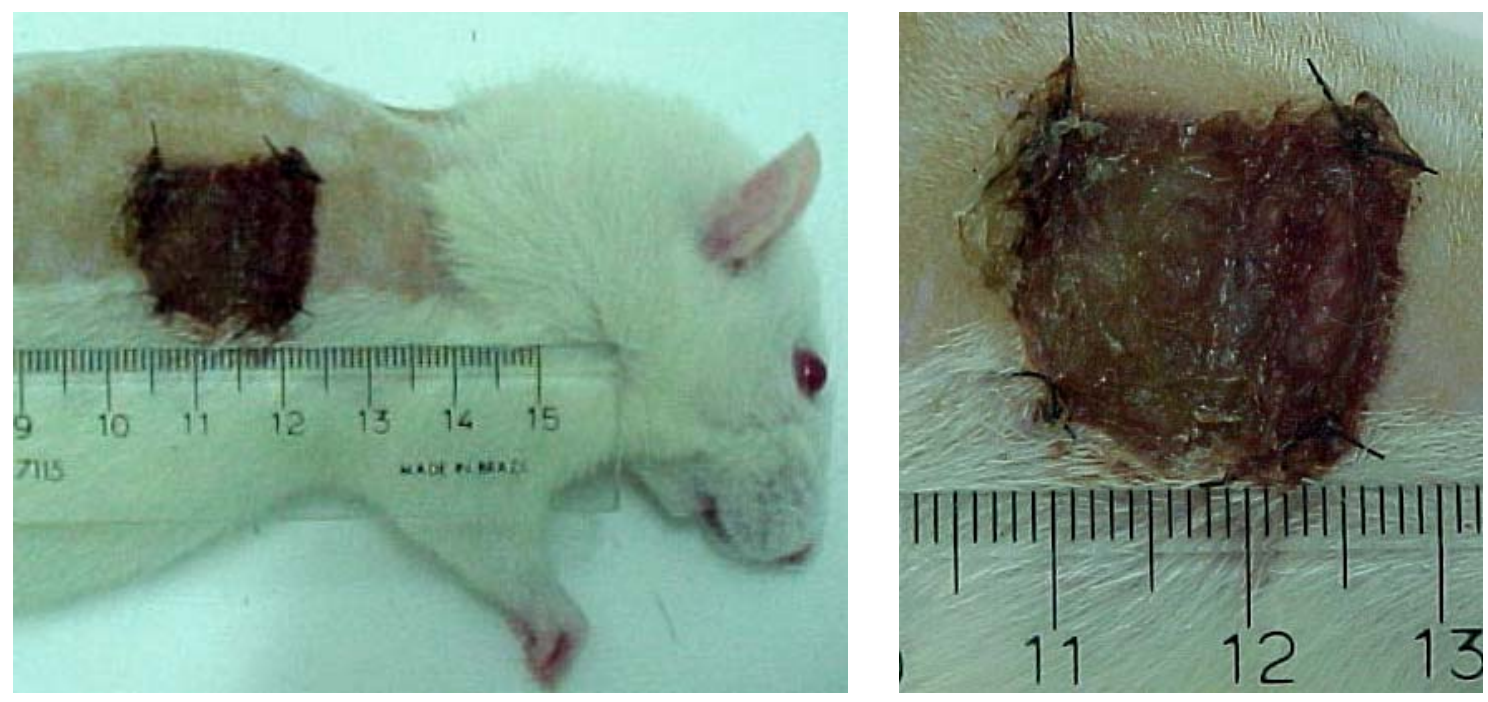

Figura 27 - Terceiro dia: Aspecto da membrana.

No quarto dia as diferenças e semelhanças já mencionadas para as feridas tratadas com soro fisiológico e as que receberam os cremes se mantiveram. As lesões permaneciam limpas, desenvolvendo tecido de granulação (principalmente 
nas bordas), sem exsudato e sem inflamação ou contaminação aparentes (presença de pus, edema e eritema acentuado). As membranas permaneciam fixadas pelos pontos e ainda tinham aspecto ressecado e escurecido (semelhantes a uma casca).

\section{IV.3.5.2. Quinto dia}

No quinto dia o tecido de granulação já cobria toda a área das lesões e parecia mais abundante nas que receberam os cremes. Tanto as tratadas com soro, como as tratadas com creme haviam reduzido em torno de $40 \%$ do seu tamanho $(0,5 \mathrm{~cm}$ nos lados), sendo que um aspecto mais viçoso ainda ressaltava nas que receberam os cremes (Figura 28).

As feridas com membranas mantinham-se secas, limpas, com presença de granulação mais discreta que nos outros 3 tratamentos; as membranas estavam escuras e secas, porém, aderidas pelos pontos (Figura 29). Sua adesão ao tecido subjacente demonstrou ser um tanto frágil, uma vez que era possível descolá-las se necessário (algumas se soltaram com a contenção e manipulação dos animais), ou seja, não estavam incorporadas ao tecido como desejado.

No sexto dia os curativos foram feitos como nos dias anteriores e não houve alteração macroscópica significativa em relação ao quinto dia.
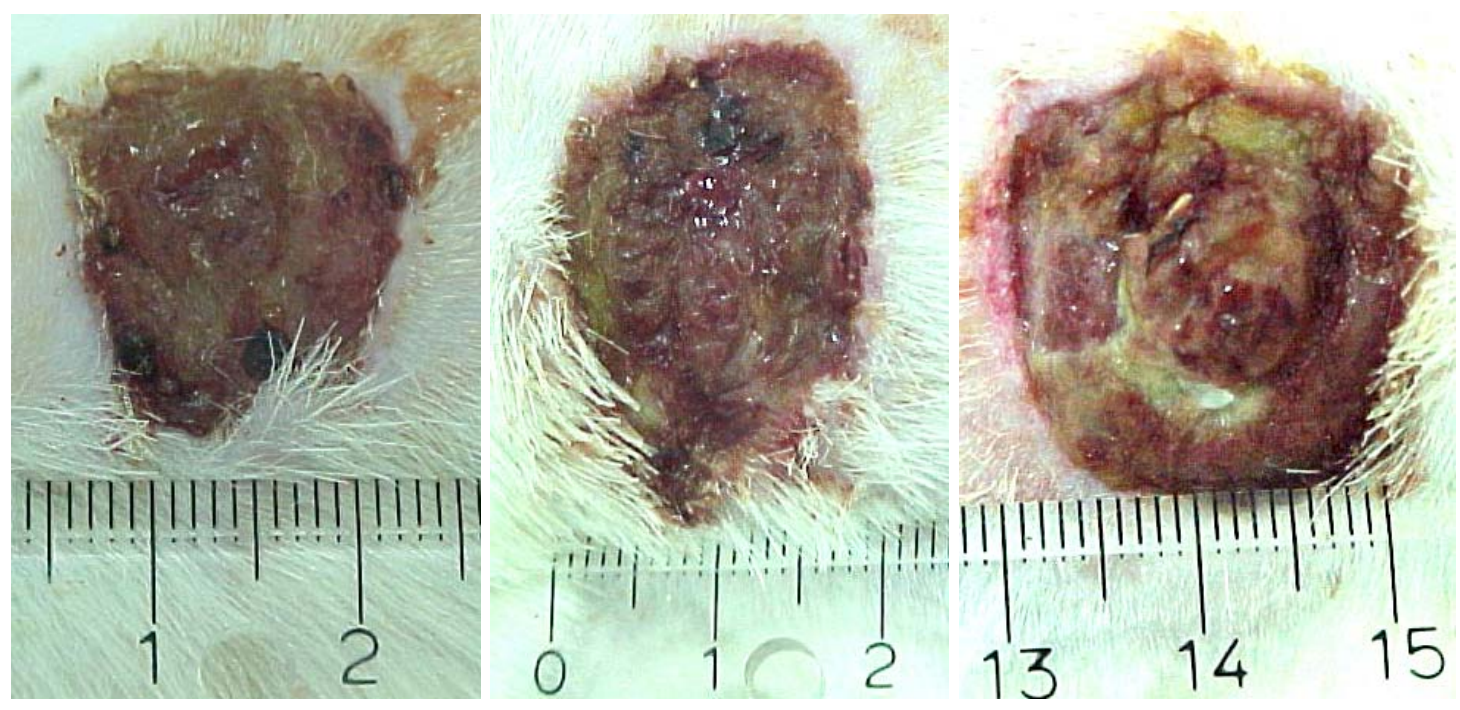

Figura 28 - Quinto dia: Tamanho e aspecto do tecido de granulação nas feridas tratadas com soro (esq.), Merck® (centro) e creme-colágeno (dir.). 

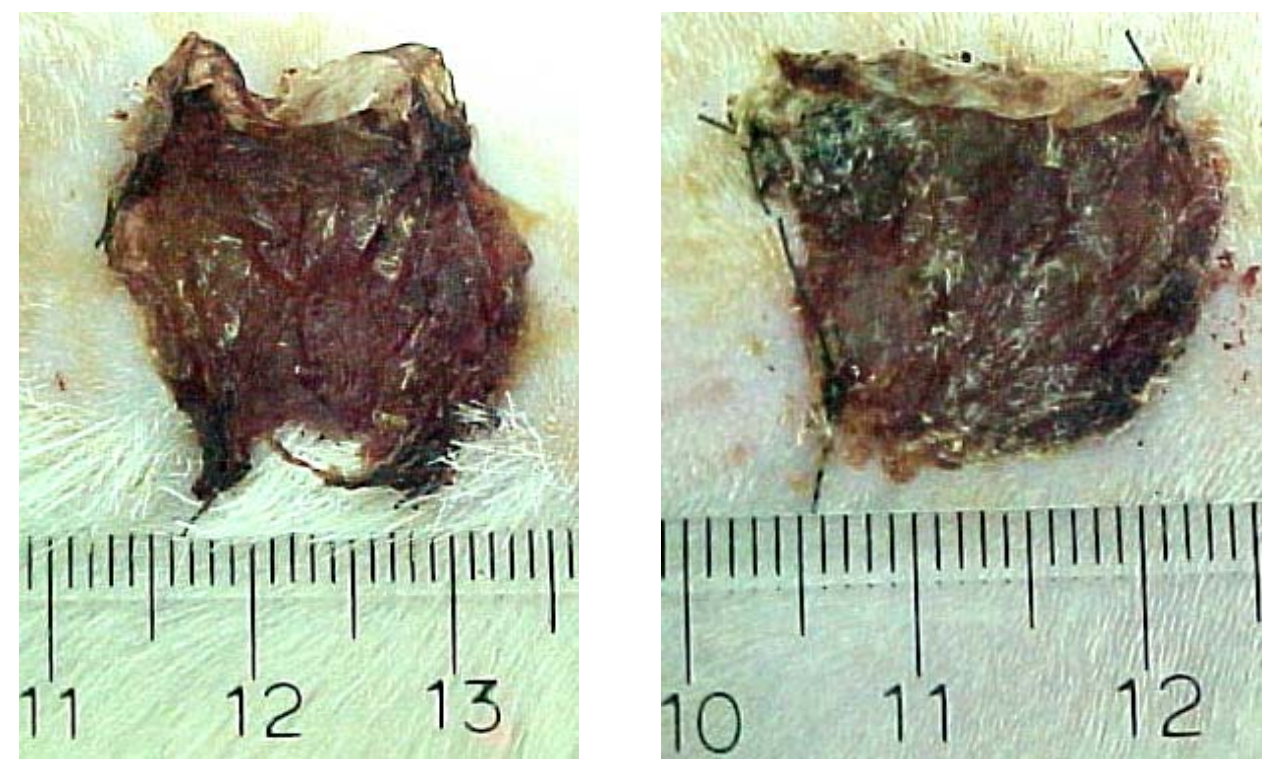

Figura 29 - Quinto dia: Tamanho e aspecto das feridas com membranas.

\section{IV.3.5.3. Sétimo dia}

As feridas tratadas com soro e com os cremes haviam reduzido seu tamanho para aproximadamente metade do original. O tecido de granulação parecia mais remodelado (menos grosseiro); não foi notada presença de contaminação (pus). Durante a contenção e manipulação dos animais, algumas crostas ou parte delas se soltaram e por baixo havia um tecido levemente úmido, com brilho (mais acentuado nas tratadas com creme do que as que receberam soro) e também sem contaminação aparente (Figura 30).

As feridas com membranas apresentaram grande redução de seus tamanhos em relação aos originais (estavam com aproximadamente $0,5 \mathrm{~cm}$ de lado). Em alguns casos, um ou mais pontos se soltaram, mas a membrana permaneceu aderida e reduzindo de tamanho junto com a área da ferida (Figura 31- imagem da esquerda). Em outros, a membrana se soltou, e a ferida continuou seu processo de cicatrização (notamos que a redução da lesão foi mais lenta após o desprendimento da membrana) (Figura 31- imagem da direita). 
No oitavo dia ficou evidente que o processo cicatricial estava sendo finalizado, pois a redução progressiva da área das lesões as tornou muito menores, mostrando a migração das margens das feridas no sentido centrípeto (reepitelização).

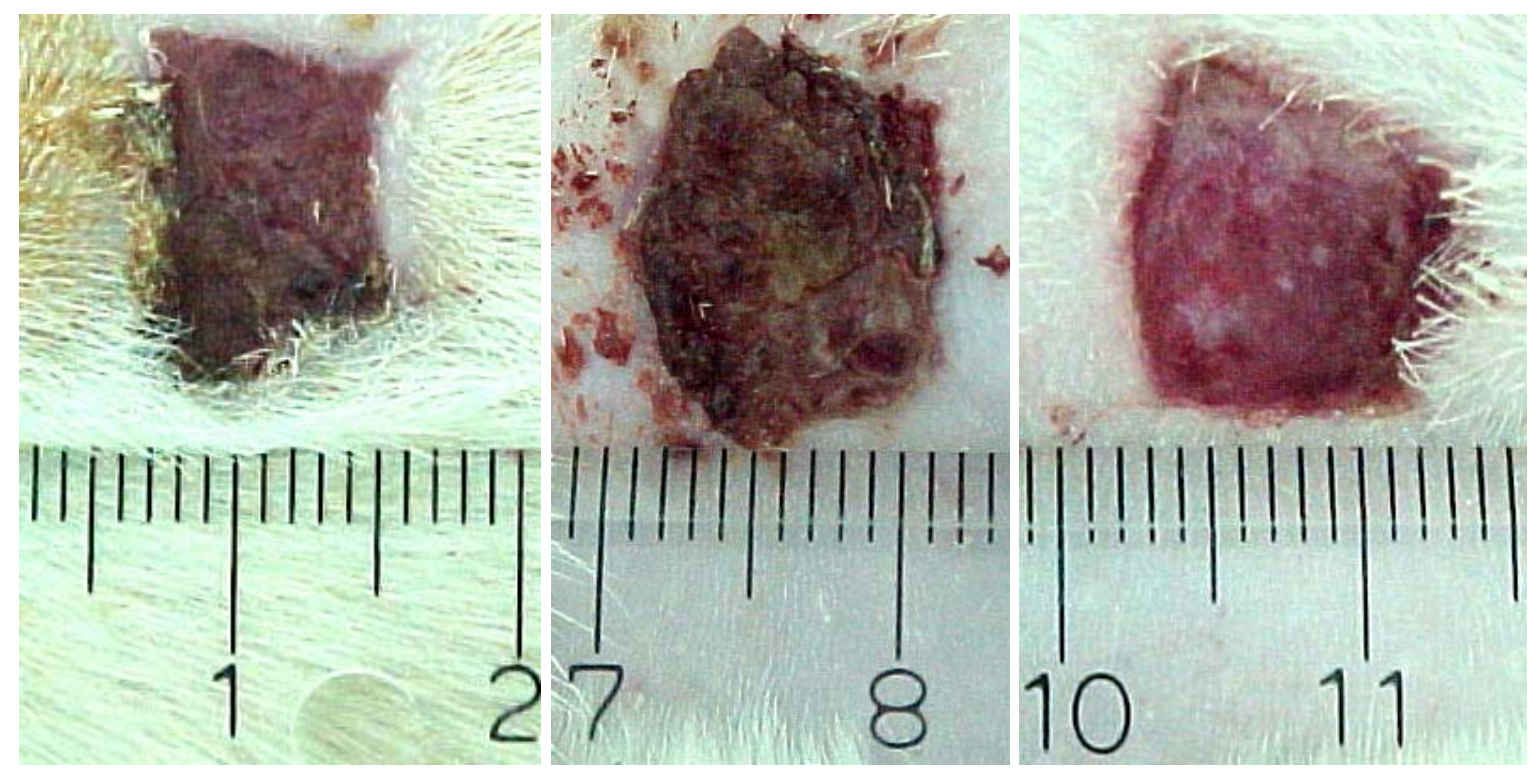

Figura 30 - Sétimo dia: aspecto das feridas tratadas com soro (esq.), Merck ${ }^{\circledR}$ (centro) e cremecolágeno (dir.).
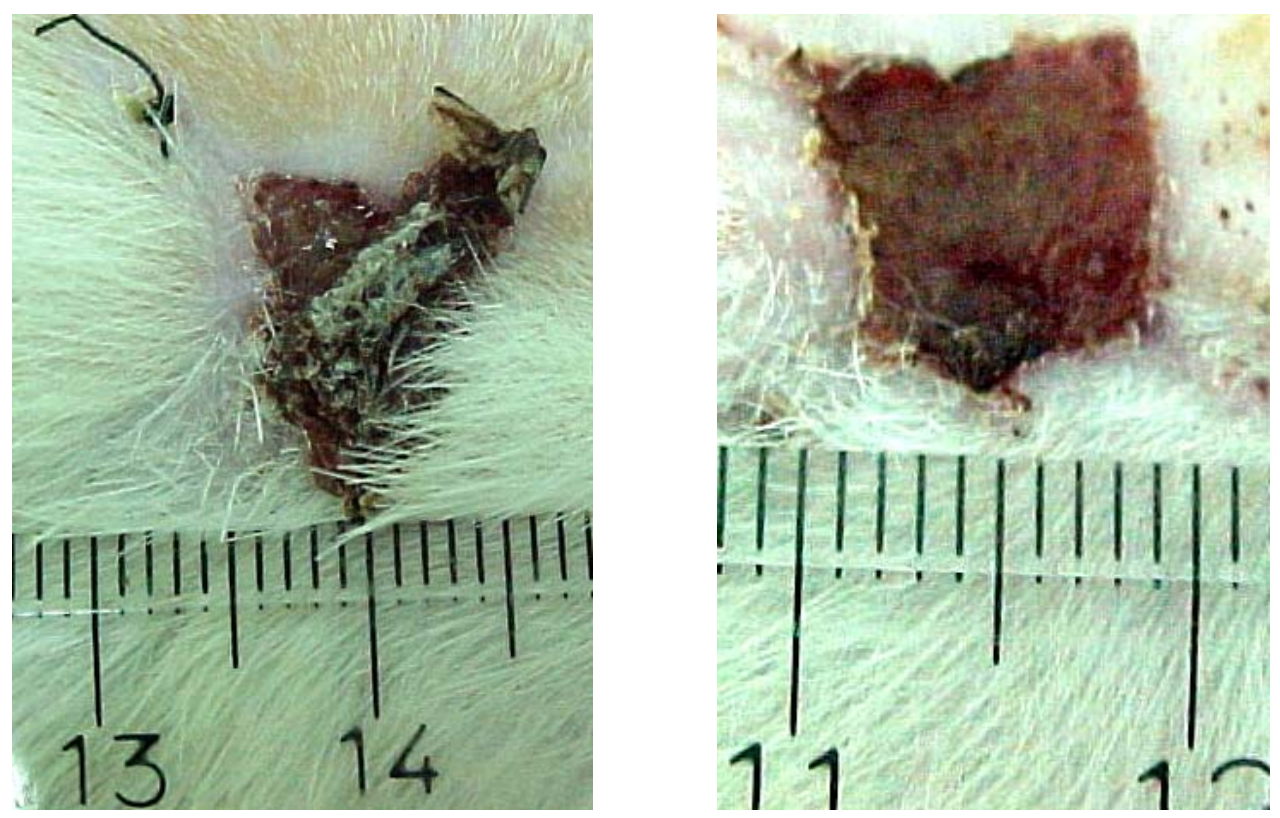

Figura 31 - Sétimo dia: aspecto das feridas com membranas. 


\section{IV.3.5.4. Nono dia}

No último dia do experimento, as feridas estavam visivelmente menores; a maioria das cascas (crostas) havia se soltado, deixando exposto o leito da ferida. Macroscopicamente, não houve grandes diferenças no tempo de cicatrização, porque a redução na área das lesões foi praticamente uniforme (apresentando em torno de $5 \mathrm{~mm}^{2}$ ) para as tratadas com soro (Figura 32), com o creme sem colágeno $\left(\right.$ Merck $\left.^{\circledR}\right)$ (Figura 33) e com o creme contendo colágeno (Figura 34). As diferenças notadas já foram mencionadas e estavam relacionadas com a aparência das feridas e com a formação do tecido de granulação (mais exacerbada no caso dos cremes).

As membranas ressecaram mesmo estando em contato com as feridas e podendo se embeber do exsudato (mesmo que este não fosse abundante) e apesar das hidratações diárias com o soro no momento dos curativos (Figura 35). Isso nos leva a crer que, uma vez exposta, a perda de líquido pela membrana se sobreponha ao ganho por absorção. Sua rápida retração pode ter auxiliado mecanicamente na cicatrização por causar a aproximação das bordas da ferida, mas como aparentemente não foi incorporada pela lesão, somente a análise histológica dará a exata noção da sua colaboração.
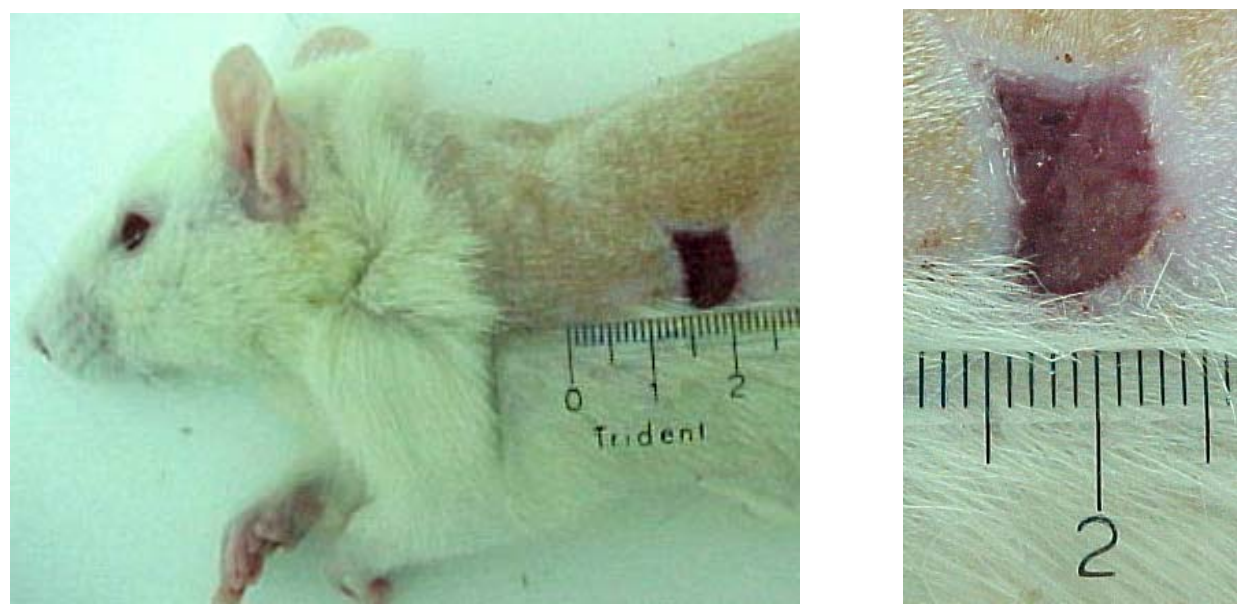

Figura 32 - Nono dia: aspecto da ferida tratada com soro fisiológico. 

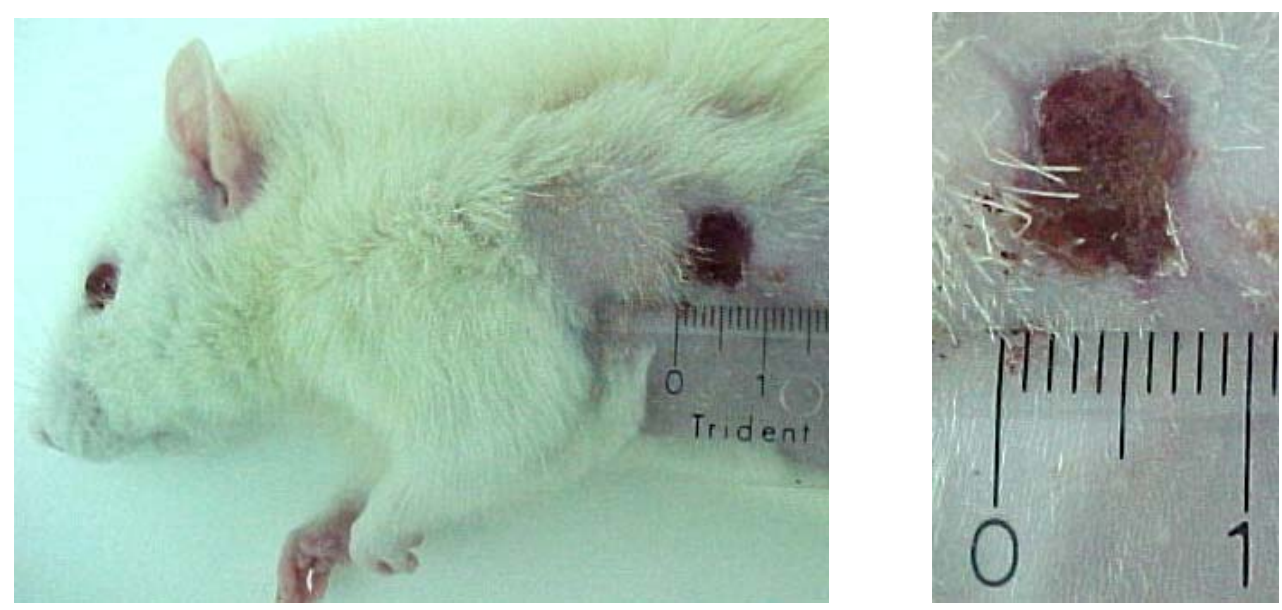

Figura 33 - Nono dia: aspecto da ferida tratada com Merck ${ }^{\circledR}$.
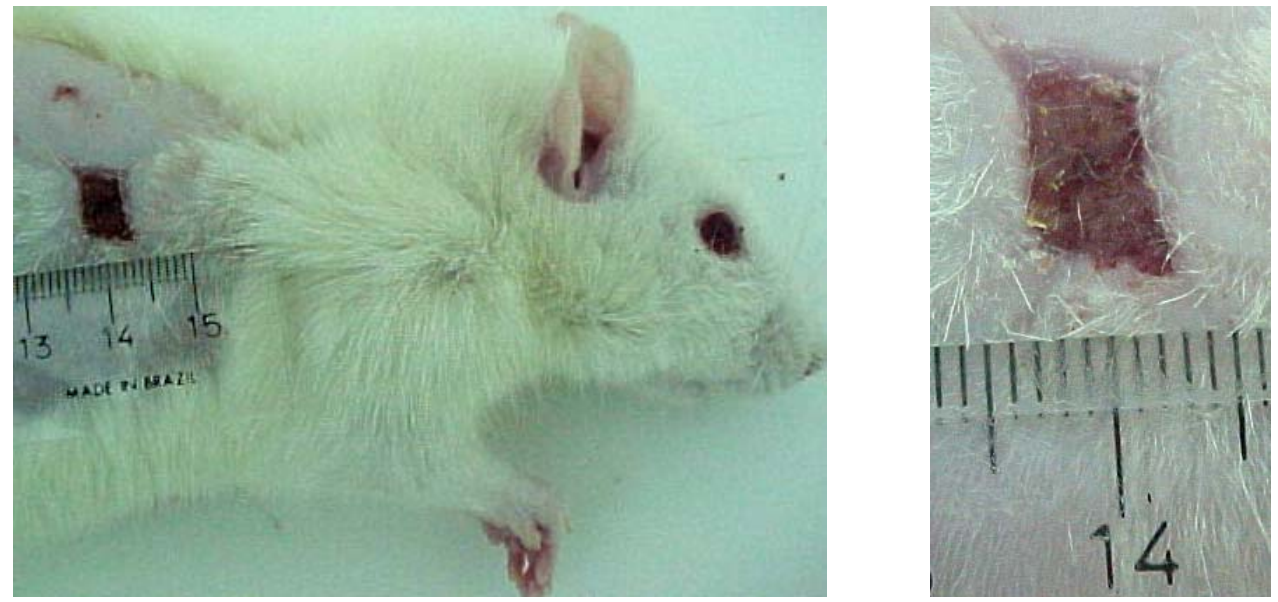

Figura 34 - Nono dia: aspecto da ferida tratada com creme com colágeno.
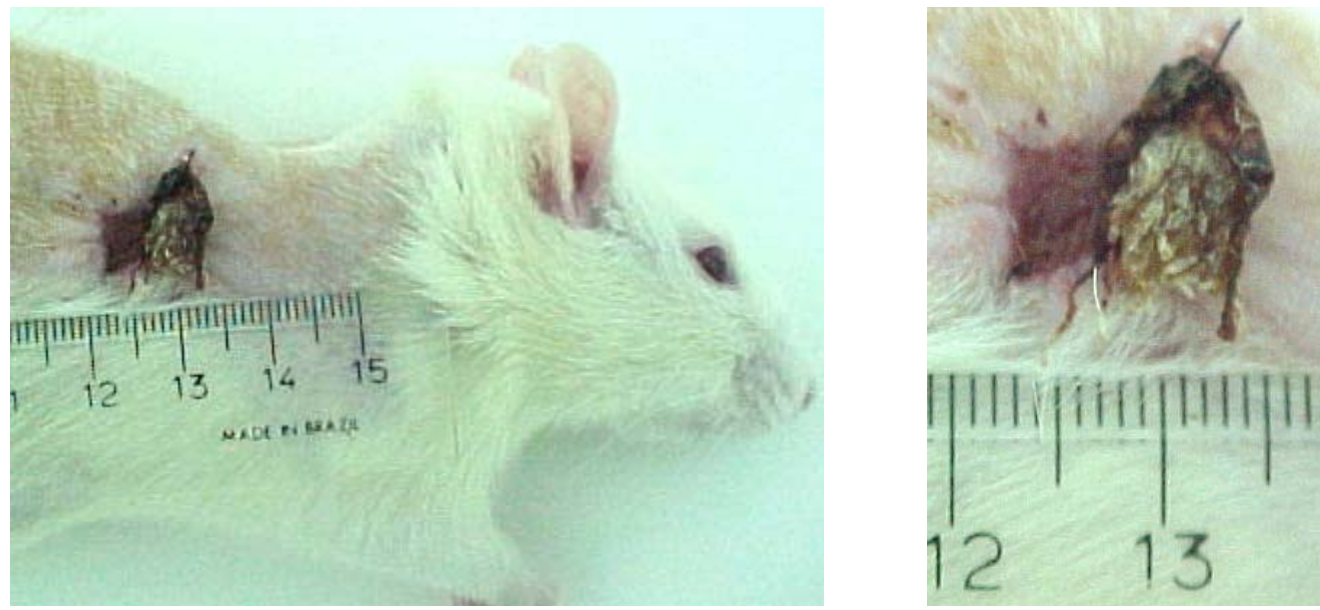

Figura 35 - Nono dia: aspecto da ferida tratada com sutura da membrana. 


\section{IV.3.6. Histologia}

A leitura e interpretação das lâminas foram feitas por Mario Cunha Pereira Leite, Mestre em Patologia pela Faculdade de Medicina Veterinária e Zootecnia USP, com auxílio de Paulo César Maiorka, Professor Doutor do Departamento de Patologia da Faculdade de Medicina Veterinária e Zootecnia - USP.

\section{IV.3.6.1. Tratamento com solução fisiológica (controle 1)}

Terceiro dia: presença de infiltrado de polimorfonucleares $(++)$ e mononucleares (++); início de neovascularização (+); colageinização ausente; tecido de granulação desorganizado, reepitelização ausente e presença de crosta.

Quinto dia: presença de infiltrado de polimorfonucleares $(++)$ e mononucleares (++); neovascularização completa (++++); colageinização ausente; início de organização do tecido de granulação; início da reepitelização e presença de crosta.

Sétimo dia: presença de infiltrado de polimorfonucleares $(++/-)$ e mononucleares $(+\quad+/-)$; neovascularização completa $(++++)$; discreta colageinização (++) e tecido de granulação maduro, apresentando fibras colágenas paralelas (Figura 36 e Figura 37); reepitelização completa e presença de crosta (Figura 38).

Nono dia: presença de infiltrado de polimorfonucleares $(+/-)$ e mononucleares (+/-); neovascularização completa $(++++)$; presença de colageinização (++ +/-); tecido de granulação maduro; reepitelização completa e presença de crosta. 


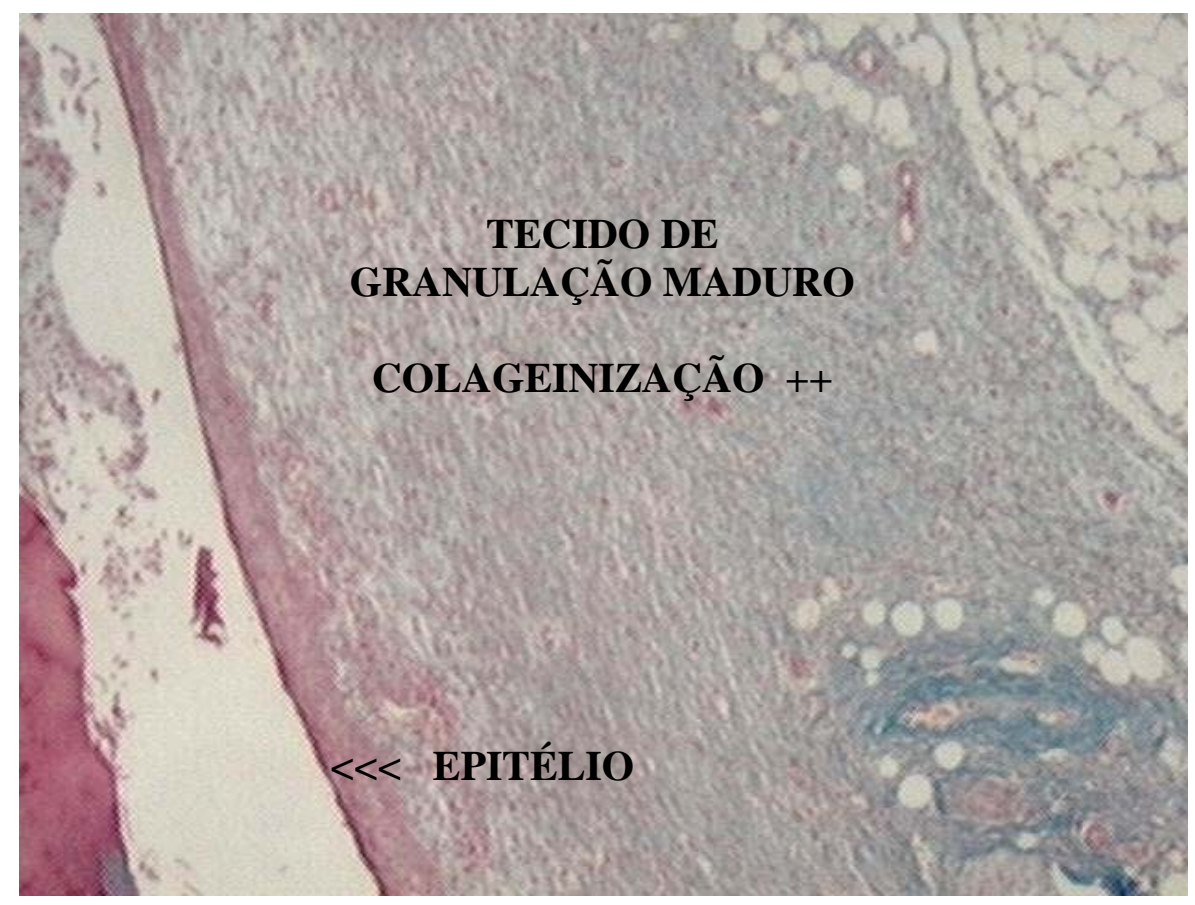

Figura 36 - Corte histológico de pele tratada com soro fisiológico (7 dias/Mallory) - aumento de $40 \mathrm{X})$.

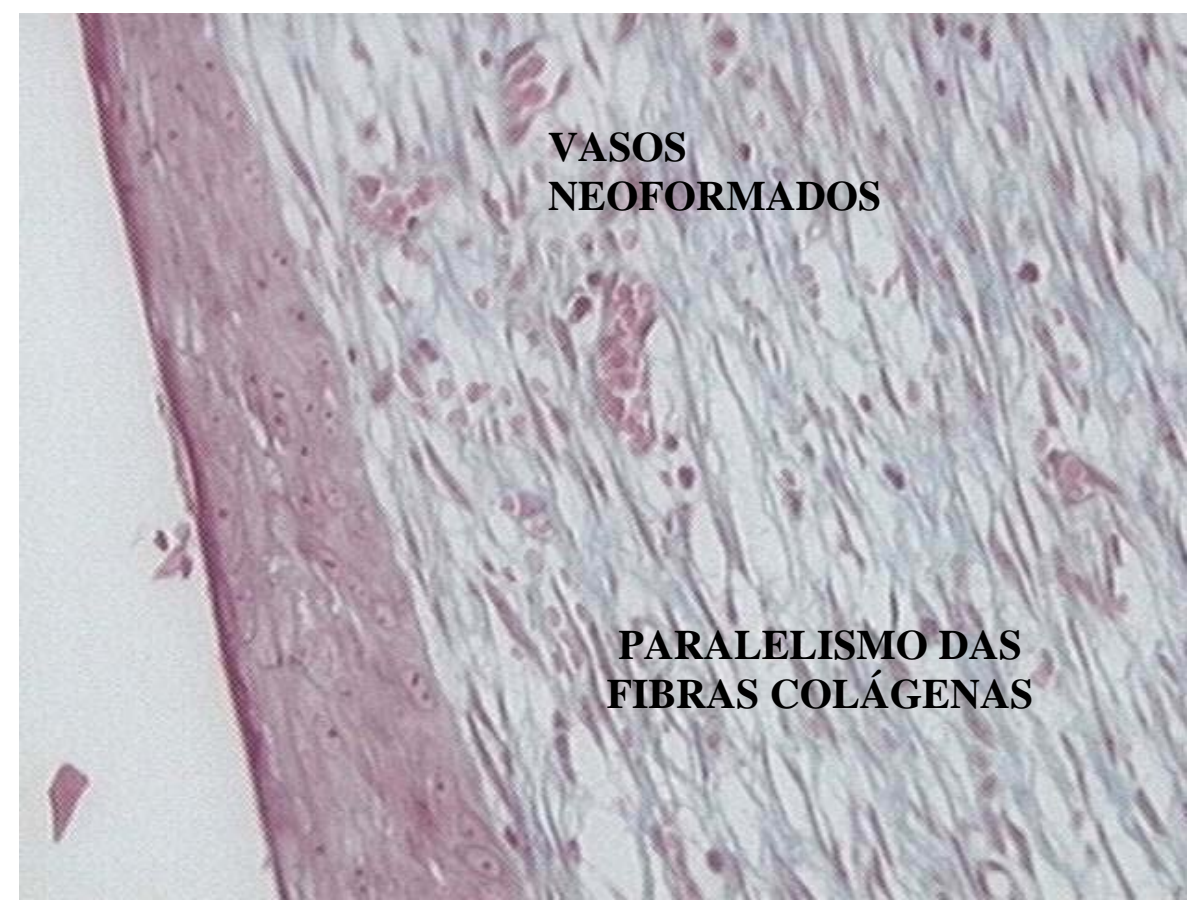

Figura 37 - Corte histológico de pele tratada com soro fisiológico (7 dias/Mallory) - aumento de 200X. 


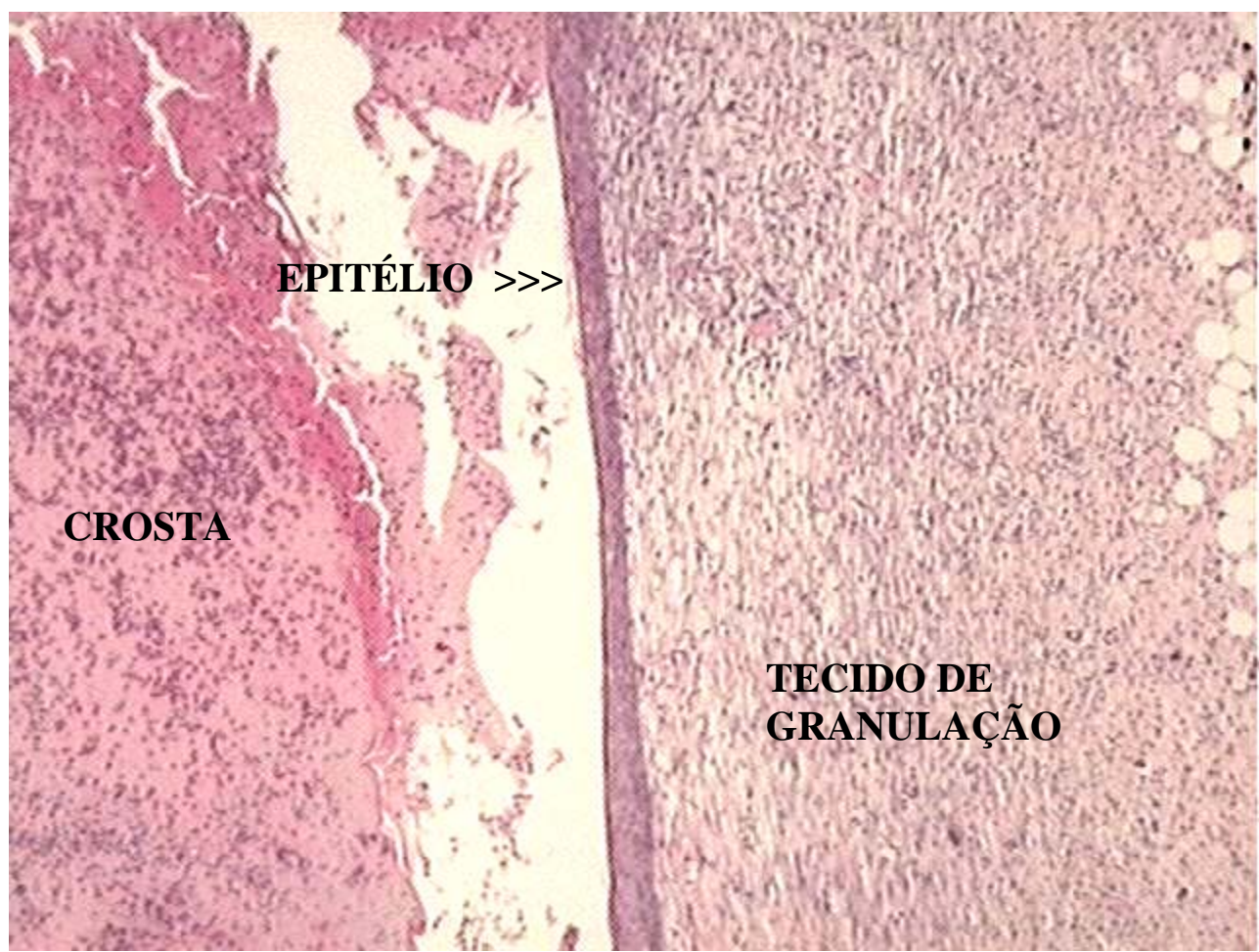

Figura 38 - Corte histológico de pele tratada com soro fisiológico (7dias/HE) - aumento de 40X.

\section{IV.3.6.2. Tratamento com creme sem colágeno - $\operatorname{Merck}^{\circledR}$ (controle 2)}

Terceiro dia: presença de infiltrado de polimorfos $(+++)$ e mononucleares $(++)$; início de neovascularização (+); colageinização ausente; tecido de granulação desorganizado e malha de fibrina com discreto infiltrado inflamatório; ausência de reepitelização e presença de crosta repleta de polimorfonucleares (Figura 39). 


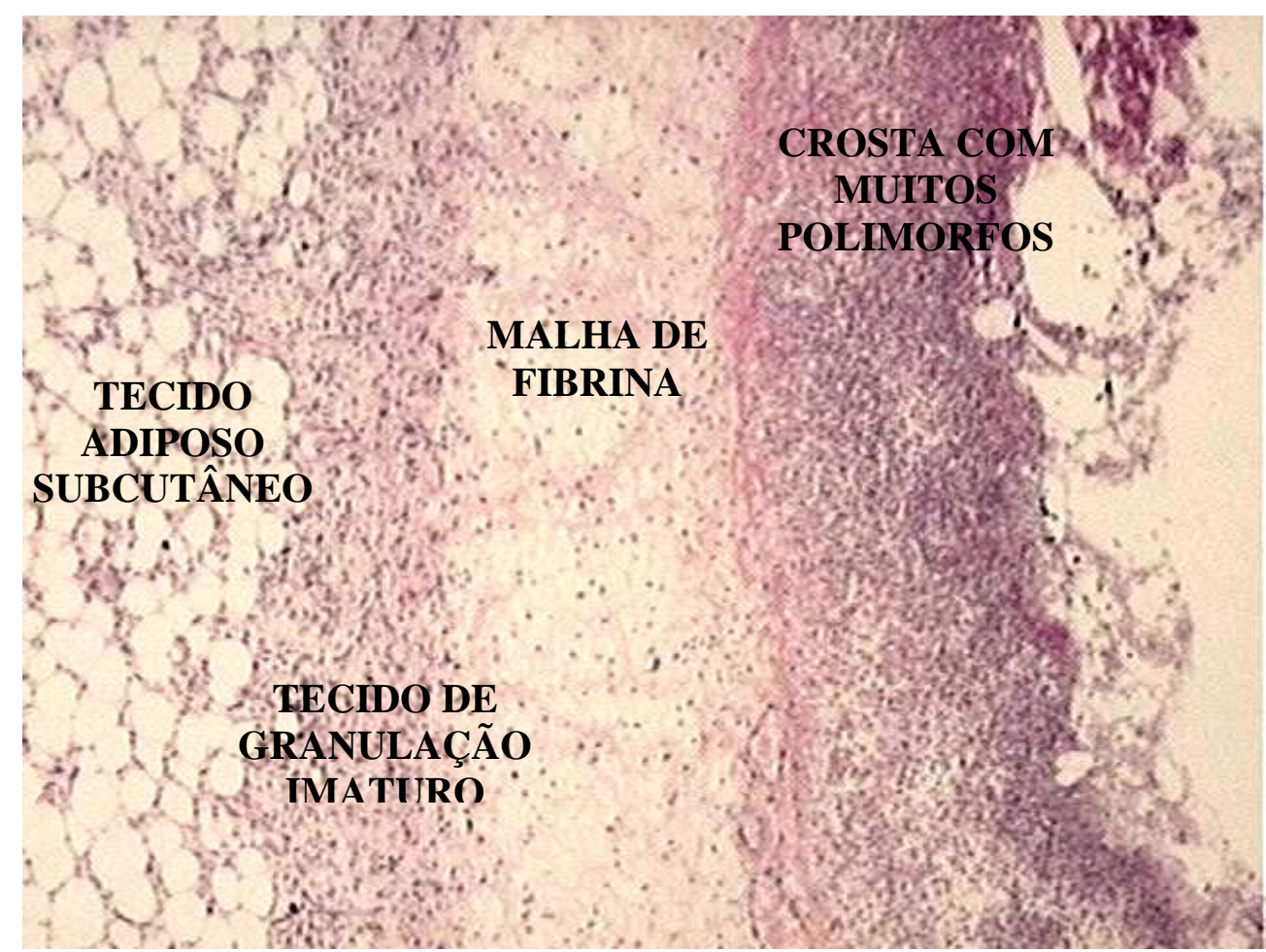

Figura 39 - Corte histológico de pele tratada com Merck ${ }^{\circledR}$ (3dias/HE) - aumento de 40X.

Quinto dia: presença de infiltrado de polimorfos (+++) e mononucleares $(+++)$; avançada neovascularização $(+++)$; colageinização ausente; início de organização do tecido de granulação; ausência de reepitelização e presença de crosta.

Sétimo dia: presença de infiltrado de polimorfos $(+++)$ e mononucleares $(++)$; neovascularização completa $(++++)$; discreta colageinização $(++)$; tecido de granulação maduro apresentando fibras colágenas paralelas; ausência de reepitelização e presença de crosta repleta de polimorfos.

Nono dia: pouca infiltração de polimorfos $(+)$ e mononucleares $(+)$; neovascularização completa; presença de colageinização $(+++/)$; tecido de granulação maduro; início de reepitelização e presença de crosta. 


\section{IV.3.6.3. Tratamento com creme contendo colágeno}

Terceiro dia: presença de infiltrado de polimorfos $(++)$ e mononucleares $(+)$; início de neovascularização (+); colageinização ausente; tecido de granulação desorganizado; ausência de reepitelização e presença de crosta.

Quinto dia: presença de infiltrado de polimorfos (++) e mononucleares $(++)$; neovascularização completa $(++++)$; colageinização ausente; início de organização do tecido de granulação; ausência de reepitelização e presença de crosta.

Sétimo dia: presença de infiltrado de polimorfos $(+)$ e mononucleares (++ $+/$ ); neovascularização completa $(++++)$; presença de colageinização $(+++/-)$; tecido de granulação em organização apresentando paralelismo incompleto das fibras colágenas; ausência de reepitelização e presença de crosta repleta de polimorfos.(Figura 40 e Figura 41)

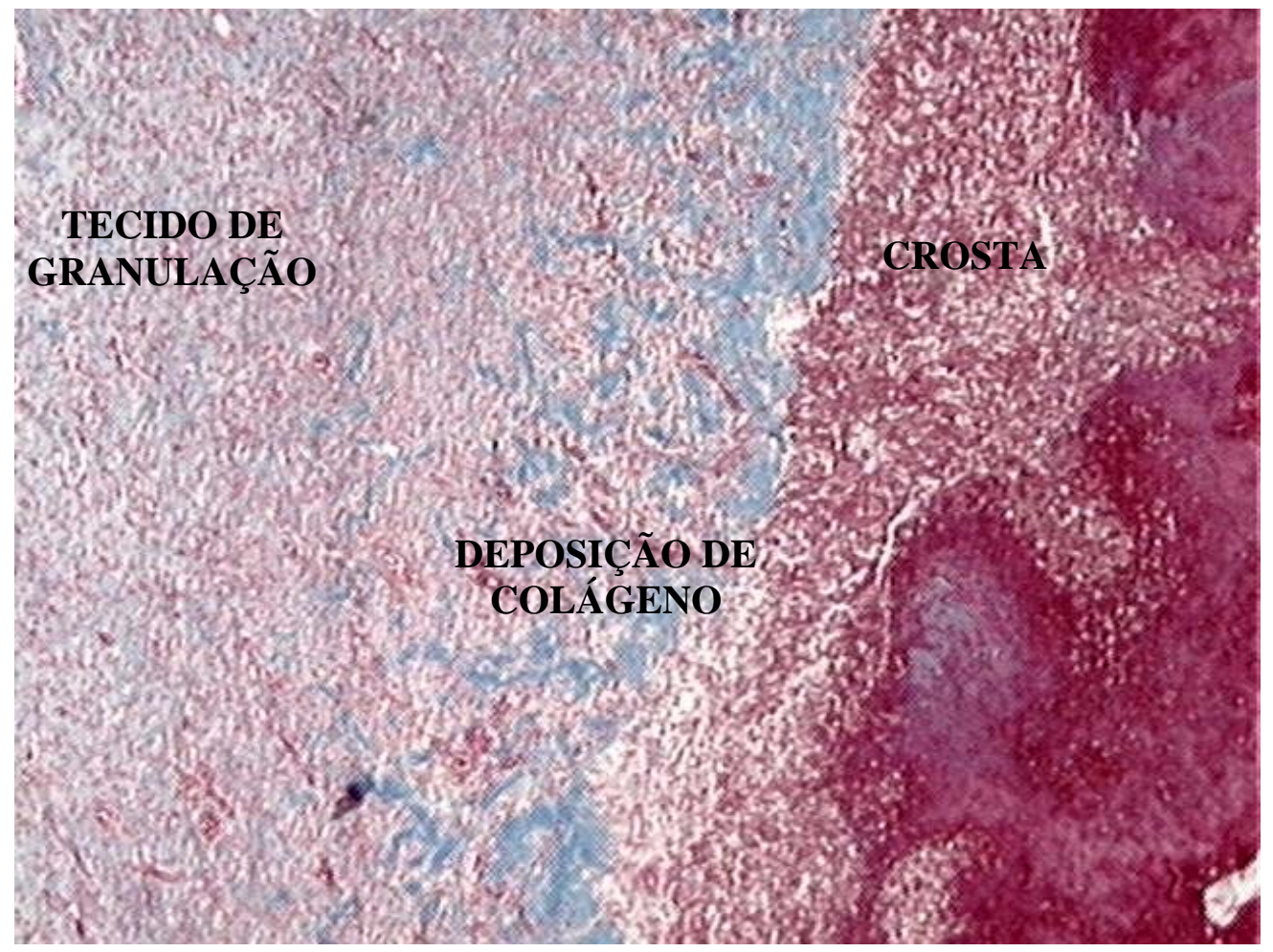

Figura 40 - Corte histológico de pele tratada com creme com colágeno (7dias/Mallory) - aumento de 40X. 


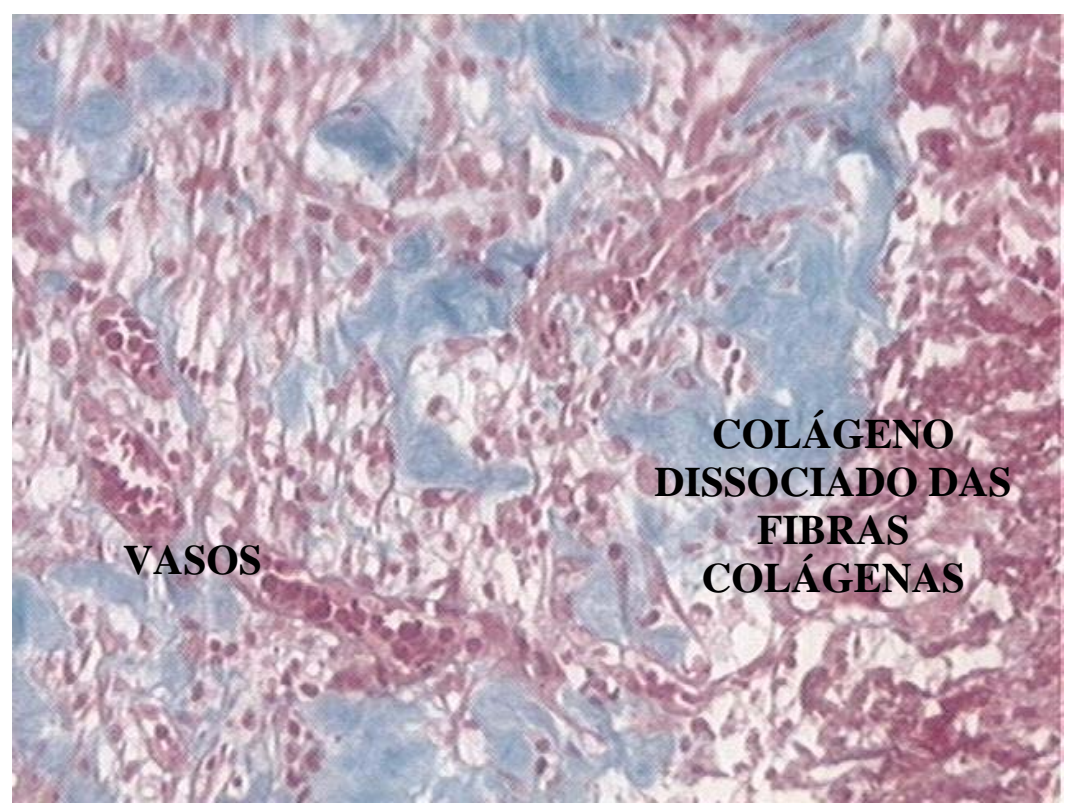

Figura 41 - Corte histológico de pele tratada com creme com colágeno (7dias/Mallory) - aumento de 200X.

Nono dia: ainda alguma presença de polimorfos (+ +/-) e mononucleares $(++)$; neovascularização completa $(++++)$; presença de colageinização (+++) (Figura 42 e Figura 43); tecido de granulação maduro; início de reepitelização (Figura 44) e presença de crosta.

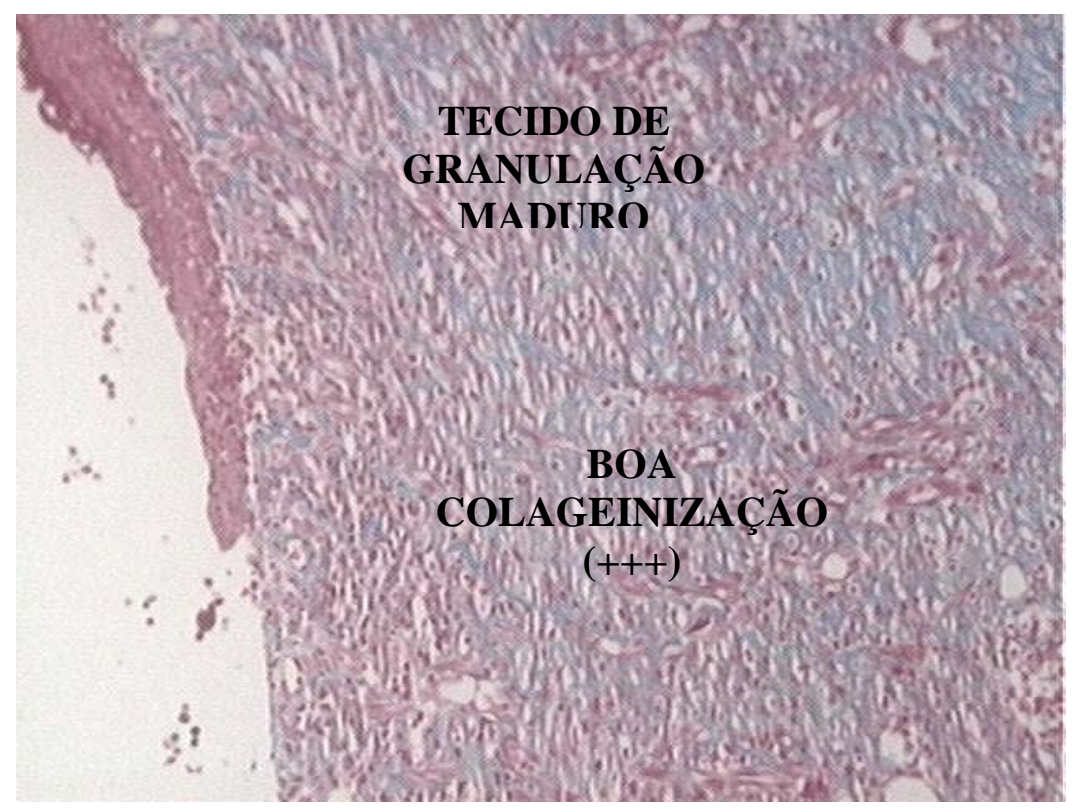

Figura 42 - Corte histológico de pele tratada com creme com colágeno (9 dias/Mallory) - aumento de $40 X$. 


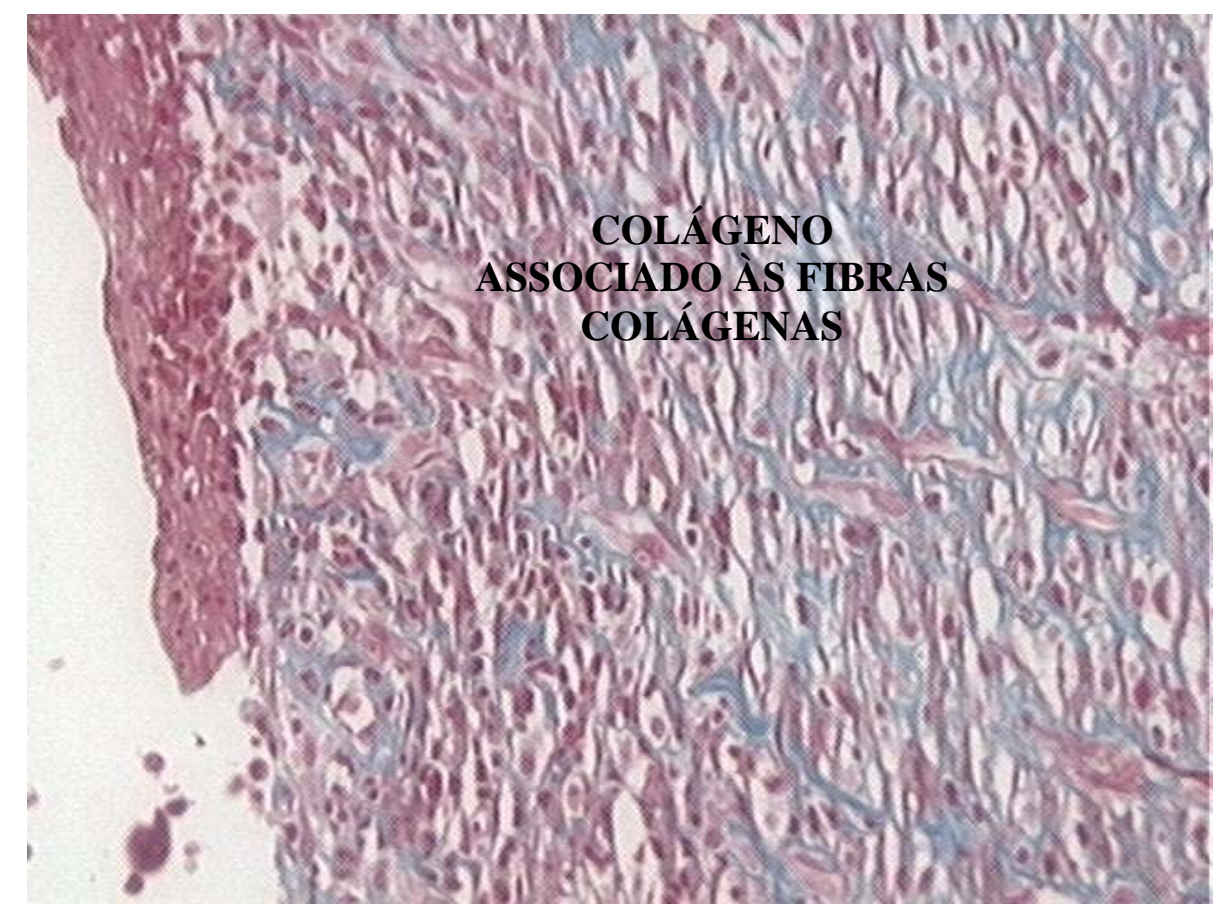

Figura 43 - Corte histológico de pele tratada com creme com colágeno (9 dias/Mallory) - aumento de 200X.

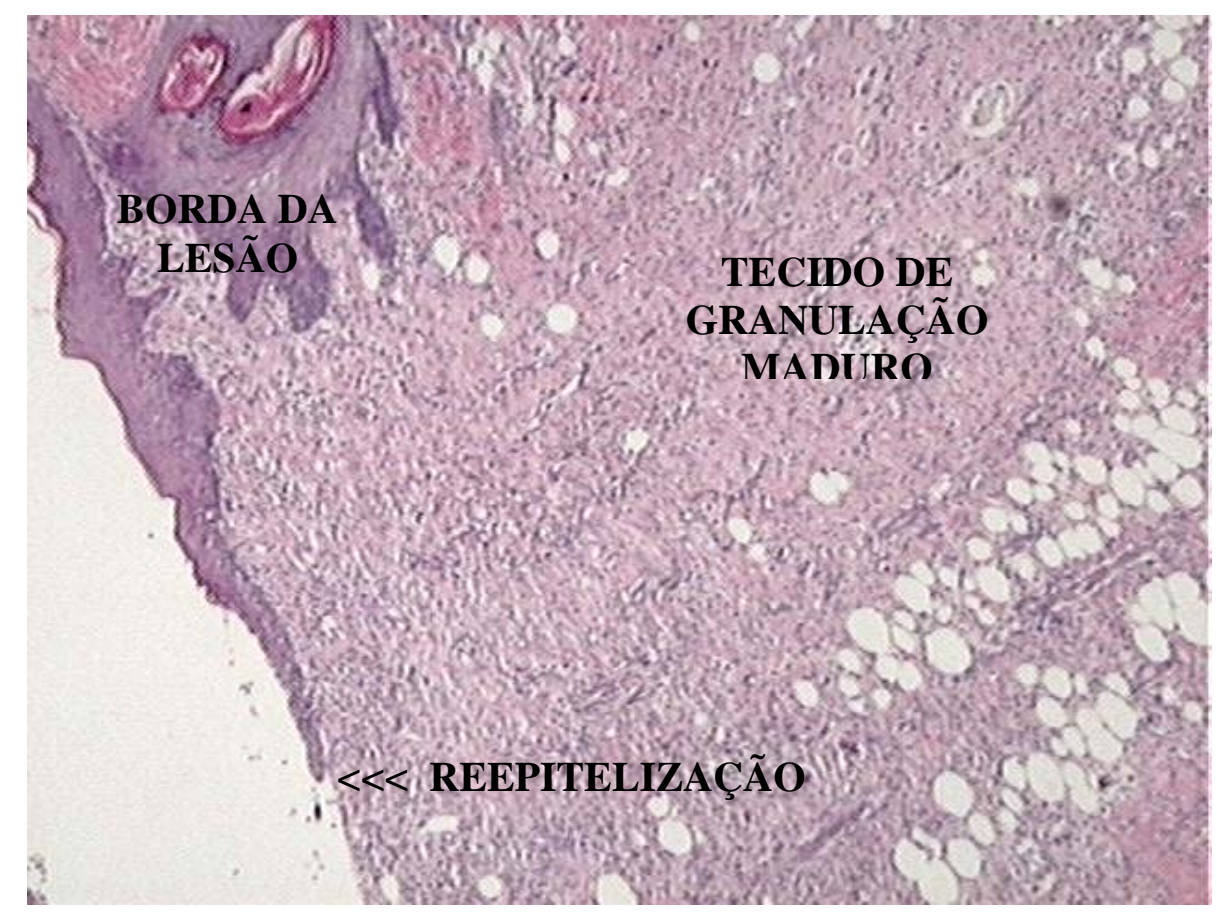

Figura 44 - Corte histológico de pele tratada com creme com colágeno (9 dias/HE) - aumento de 40X. 


\section{IV.3.6.4. Tratamento com sutura da membrana}

Terceiro dia: pouca presença de infiltrado de polimorfos (+/-) e mononucleares (+/-); início de neovascularização (+); colageinização ausente; início de organização do tecido de granulação e presença de malha de fibrina sem infiltrado inflamatório; ausência de reepitelização e crosta.

Quinto dia: presença discreta de infiltrado de polimorfos (+/-) e mononucleates (+); neovascularização completa $(++++)$; ausência de colageinização; tecido de granulação em organização apresentando paralelismo incompleto das fibras colágenas; início de reepitelização; ausência de crosta.

Sétimo dia: presença de infiltrado de polimorfos $(++/-)$ e mononucleares $(+++/)$; neovascularização completa $(++++)$; discreta colageinização (++) (Figura 45 e Figura 46); tecido de granulação maduro com fibras colágenas paralelas; adiantado processo de reepitelização e ausência de crosta (Figura 47).

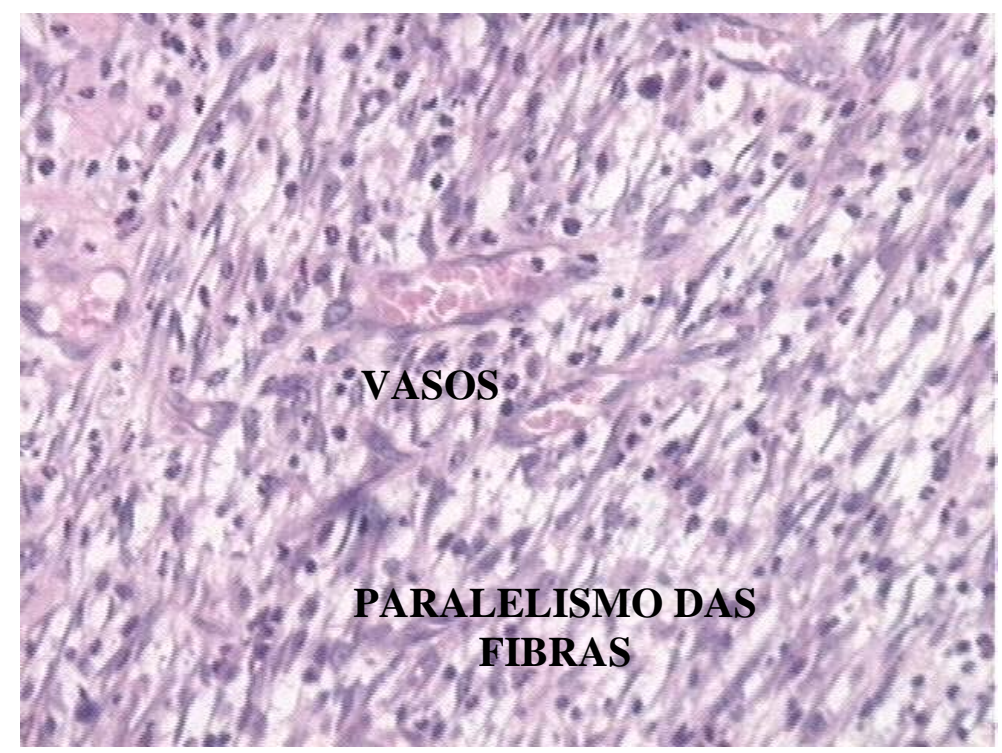

Figura 45 - Corte histológico de pele tratada com sutura da membrana (7 dias/HE) - aumento de 200X. 


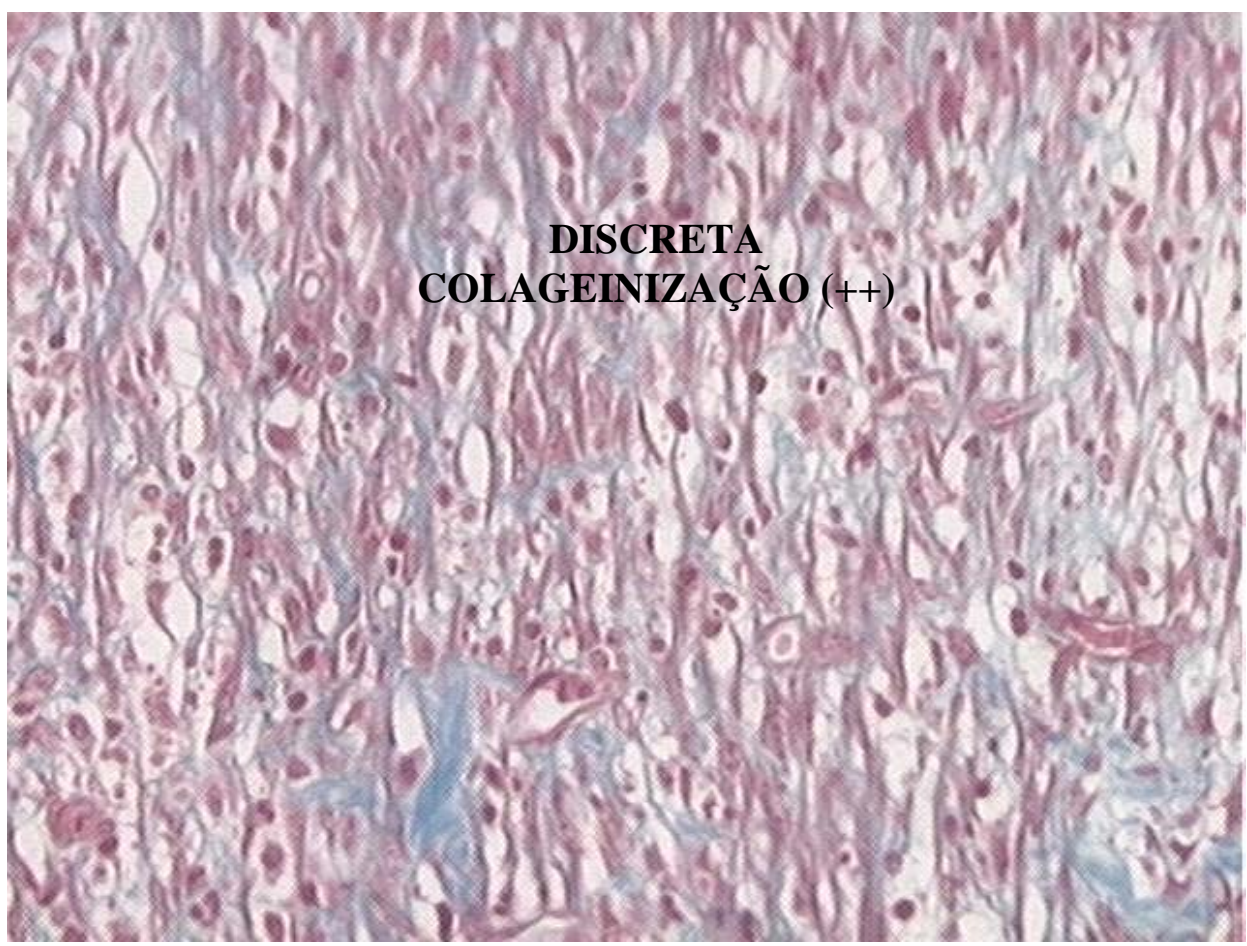

Figura 46 - Corte histológico de pele tratada com sutura da membrana (7 dias/Mallory) - aumento de 200X.

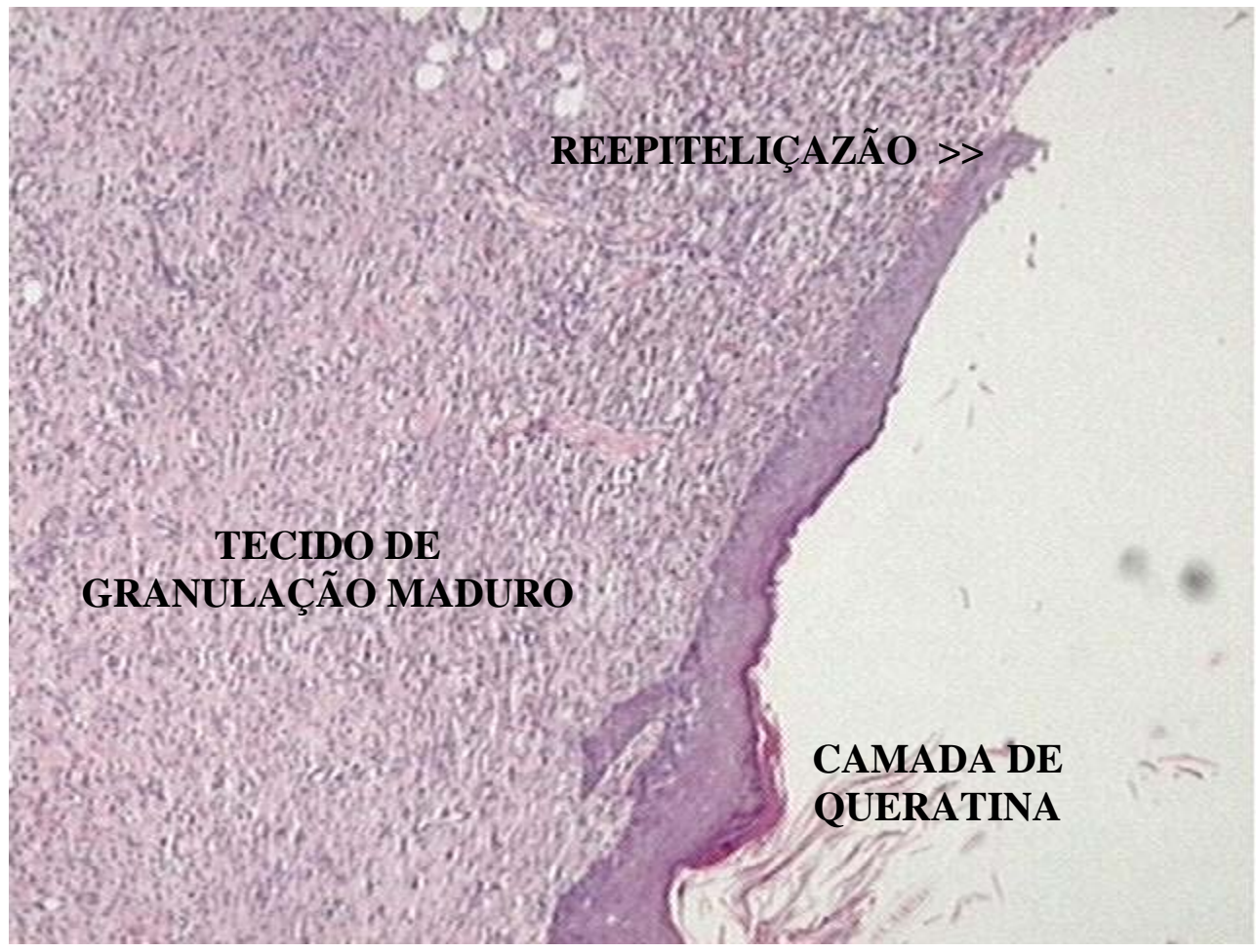

Figura 47 - Corte histológico de pele tratada com membrana (7 dias/HE) - aumento de 40X. 
Nono dia: pouco infiltrado de polimorfos $\left(^{+}\right)$e pouca presença de mononucleares (+/-); neovascularização completa; discreta colageinização (++); tecido de granulação maduro; reepitelização completa (++++) e ausência de crosta.

O número de células presentes em cada tratamento, nos diferentes dias avaliados, foi contado em um aumento de 400X e representado por um esquema de "cruzes". A interpretação do patologista foi comparativa e estimativa, considerando o material histológico disponível, assim como também por comparação foi feita a determinação das cruzes para os demais itens não celulares. A relação entre número de células e cruzes está relacionada abaixo:

- meia cruz (+/-): de 0 a 10 células / campo;

- uma cruz (+): de 8 a 15 células / campo;

- duas cruzes (++): de 25 a 50 células / campo;

- três cruzes (+++): 40 a 80 células / campo.

O resumo dos resultados descritos está apresentado na Tabela 3 a seguir: 
Tabela 3 - Resumo dos resultados histológicos.

\begin{tabular}{|c|c|c|c|c|c|}
\hline DIA & ÍTEM & SORO & MERCK® & CR/COL & MEMBR. \\
\hline \multirow{7}{*}{ 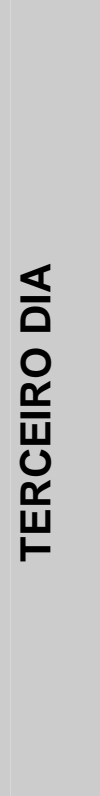 } & POLIMORFOS & ++ & +++ & ++ & $+l-$ \\
\hline & MONONUCL. & ++ & ++ & + & $+1-$ \\
\hline & NEOVASCUL. & início + & início + & início + & início + \\
\hline & COLAGEINIZ. & ausente & ausente & ausente & ausente \\
\hline & GRANULAÇÃO & desorgan. & desorgan. & desorgan. & início org. \\
\hline & REEPITELIZ. & ausente & ausente & ausente & ausente \\
\hline & CROSTA & presente & pres.(poli) & presente & ausente \\
\hline \multirow{7}{*}{ 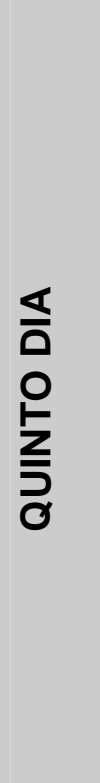 } & POLIMORFOS & ++ & +++ & ++ & $+1-$ \\
\hline & MONONUCL. & ++ & +++ & ++ & + \\
\hline & NEOVASCUL. & ++++ & +++ & ++++ & ++++ \\
\hline & COLAGEINIZ. & ausente & ausente & ausente & ausente \\
\hline & GRANULAÇÃO & início org. & início org. & início org. & em organ. \\
\hline & REEPITELIZ. & início & ausente & ausente & início \\
\hline & CROSTA & presente & presente & presente & ausente \\
\hline
\end{tabular}


(continuação da Tabela 3)

\begin{tabular}{|c|c|c|c|c|c|}
\hline \multirow{7}{*}{ 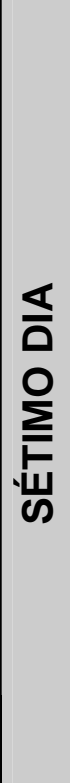 } & POLIMORFOS & $+1-$ & +++ & + & $++l-$ \\
\hline & MONONUCL. & $++l-$ & ++ & $+++l-$ & $+++l-$ \\
\hline & NEOVASCUL. & ++++ & ++++ & ++++ & ++++ \\
\hline & COLAGEINIZ. & ++ & ++ & $+++1-$ & ++ \\
\hline & GRANULAÇÃO & maduro & maduro & em organ. & maduro \\
\hline & REEPITELIZ. & ++++ & ausente & ausente & ++++ \\
\hline & CROSTA & presente & pres.(poli) & pres.(poli) & ausente \\
\hline \multirow{7}{*}{ 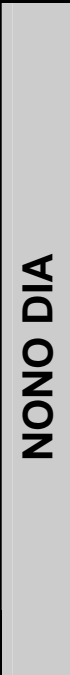 } & POLIMORFOS & $+1-$ & + & $++1-$ & + \\
\hline & MONONUCL. & $+1-$ & + & ++ & $+1-$ \\
\hline & NEOVASCUL. & ++++ & ++++ & ++++ & ++++ \\
\hline & COLAGEINIZ. & ++ & ++ & $+++l-$ & ++ \\
\hline & GRANULAÇÃO & madura & madura & madura & madura \\
\hline & REEPITELIZ. & ++++ & início & início & ++++ \\
\hline & CROSTA & presente & presente & presente & ausente \\
\hline
\end{tabular}


Macroscopicamente, a evolução do processo cicatricial frente a cada um dos tratamentos propostos apresentou algumas diferenças no que diz respeito ao aspecto do tecido de granulação, à quantidade de crosta formada e à aparência (cor e brilho) do tecido correspondente à área lesada, o que está intimamente ligado à irrigação sanguínea (neovascularização) do local. O tempo de contração da ferida (diminuição da lesão) pareceu ser similar para os dois grupos controle e o tratamento com creme contendo colágeno, mas foi menor para o grupo tratado com sutura da membrana (mensuração com régua); este não apresentou crosta. Nenhum grupo do experimento apresentou exsudato, contaminação aparente (pus), ou inflamação exacerbada (hiperemia e edema acentuados). Importante ressaltar que nenhum dos quase 100 (cem) animais usados para o estudo, desde os testes preliminares e pilotos até o experimento final, apresentou mudança de comportamento, alteração de apetite ou perda de peso.

Histologicamente, o grupo de controle que recebeu o soro demonstrou a eficiência do processo de cicatrização do organismo em relação ao desafio que foi provocado. O processo de cicatrização das feridas neste grupo não foi tão inferior na análise histológica quanto indicava o acompanhamento macroscópico, demonstrando a efetiva capacidade de regeneração dos tecidos. O grupo de controle que recebeu o Merck ${ }^{\circledR}$ foi o que apresentou maior contaminação em todas as etapas, pela quantidade de polimorfos e mononucleares presentes. $\mathrm{O}$ creme com colágeno foi um pouco superior no grau de colageinização comparando com os outros três grupos em estudo; isso pôde ser notado no exame histológico a partir do sétimo dia, quando um grande acúmulo de colágeno foi notado entre a crosta e o tecido de granulação (Figura 40). Posteriormente, as células podem ter passado a utilizá-lo, pois, nas análises histológicas do nono dia, todo colágeno já se encontrava uniformemente distribuído entre as fibras (Figura 42). O tratamento com a membrana foi mais eficiente no que diz respeito ao tempo de formação e maturação do tecido de granulação. A pequena quantidade de células de defesa demonstrou o menor grau de contaminação nesta opção de tratamento; a reepitelização foi rápida (com início do terceiro e conclusão no quinto dia) e não houve aderência ou deformação na região injuriada. 


\section{V - CONCLUSÕES}

A mistura creme/gel de colágeno é estável e pode ser armazenada em temperatura ambiente onde conserva suas propriedades viscoelásticas mesmo com pequena alteração em sua cor. $\mathrm{O}$ creme e o gel de colágeno coexistem no frasco sem que provoquem quaisquer alterações entre si. Após 70 dias, a amostra mantida sob refrigeração torna-se mais viscosa devido à perda de água por condensação.

A região tóraco-dorsal superior demonstrou ser uma ótima opção para experimentos que envolvem lesões induzidas em pele de rato porque minimiza o contato do ferimento com a cama de serragem e evita a autoflagelação.

Apesar de não ter havido uma grande diferença na cicatrização das feridas planas dos dois grupos de controle (tratamento com soro e creme sem colágeno) e no grupo que recebeu tratamento do creme contendo colágeno, a presença deste no creme indicou uma pequena diferença no grau de colageinização, o que demonstra serem válidas mais investigações nesta direção, buscando uma melhor proporção creme:gel e/ou diferentes concentrações para o gel de colágeno.

A membrana demonstrou ser uma boa opção para o reparo de lesões por ser de fácil obtenção e armazenamento, ter baixo custo e ser excelente para manuseio (maleável e resistente), além de atender às principais exigências mencionadas na literatura para qualquer curativo biológico oclusivo - possuir ação antibacteriana, estimular os processos de granulação, contração e epitelização, formar barreira física contra invasão bacteriana, assim como propiciar retenção do exsudato. È necessário que haja mais estudos para a aplicação em pele de modo que se consiga desenvolver um meio de evitar o ressecamento da membrana e, ao mesmo tempo, promover sua incorporação. 


\section{REFERÊNCIAS BIBLIOGRÁFICAS}

ABLA, L.E.F.; ISHIZUKA, M.M.A. (1995). Fisiopatologia das Feridas. In: Ferreira LM. Man. Cirurg. Plást.. São Paulo: Atheneu; p.5-11.

ABRAHAM, G.A.et al. (2000). Evaluation of the porcine intestinal collagen layer as a biomaterial, J. Biomed. Mat. Res., v.51, n.3, p.442-452, Sept.

ALPASLAN, C.; ALPASLAN, G.H.; OYGUR, T. (1997). Tissue reaction to three subcutaneously implanted local hemostatic agents. Brit. J. Oral Maxillofac. Surg.. v.35, n.2, p.129-132, Apr.

ANDRADE, M.N.B.; SEWARD, R.; MELO, J.R.C. (1992). Curativos. Rev. Méd. Minas Gerais, v.2, n.4, p. 228-36.

ARNOLD Jr, H.L.; ODOM, R.B.; JAMES, W.D. (1994). A pele: estrutura básica e função. Doenças básicas da pele de Andrews: Dermatol. Clín., p.1-14.

BADYLAK, S. et al.(1999). Endothelial cell adherence to small intestinal submucosa: an acellular bioscaffold. Biomat., Guildford, v.20, n.21, p.2257-63, Nov.

BARTLETT, R.H. (1981). Skin substitutes. J. Trauma, Baltimore, v.21, p.731.

BELL, E. et al. (1981). Living tissue formed in vitro and accepted as skin-equivalent tissue of full thickness. Science, Washington, v. 211, p.1052-1054, Mar.

BET, M.R. et al. (2001). Characterization of Polyanionic Collagen Prepared by Selective Hydrolysis of Asparagine and Glutamine Carboxyamide Side Chains. Biomacromol., Washington, v.2, n.4, p.1074-1079.

BLANES, L. (2004). Tratamento de feridas. In: Silva J.C.C.B. Cirurgia vascular: guia ilustrado. São Paulo. Disponível em: :<http://www.bapbaptista.com>. Acesso em: 23 jul. 2005.

BURKE, J.F. (1983). Observations on the development of an artificial skin: presidential address. J. Trauma, Baltimore, v.23, n.7, p.543-551, July.

BURKE, J.F. et al. (1981). Successful use of a physiologically acceptable artificial skin in the treatment of extensive burn injury. Ann. Surg, Philadelphia, v.194, n.4, p.413-428, Oct.

CANDIDO, L.C.(2001). Nova abordagem no tratamento de feridas. SENAC-SP.

COOK $^{\circledR}$ SIS $^{\circledR}$ Technology (2005). Disponível em: 
<http://www.cookbiotech.com/sci/index.html>. Acesso em: 28 Apr.2005.

CRITESCU, D. (1987). Extraction of collagen from hides. [S.I.: s.n.]. RO 9190081.

CUONO, C.B. (1986). Use of cultured epidermal autografts and dermal allografts as skin replacement after burn injury. Lancet, Barcelona, v.I, n.8490, p.1123-1124, May.

DE PAULA, M. et al. (2002). Compósitos de colágeno aniônico: ramsana como géis injetáveis para correção plástica: preparação, caracterização e propriedades reológicas. Ver. Bras. Eng. Bioméd., Rio de Janeiro, v.18, n.1, p.113-122.

DESAI, M.H. et al. (1991). Lack of long-term durability of cultured keratinocyte burn-wound coverage: a case report. J. Burn Care Rehabilit., Galveston, v.12, n.6, p.540-545, Nov/ Dec.

ELLIS, D.L.; YANNAS, I.V. (1996). Collagen glycogen copolymers have been used for tissue synthesis in vivo. Biomat., Guildford, v.17, n.3, p.291-299.

ESTAÇÃO DIGITAL MÉDICA. (2005). Pinta na pele: sistema para o aprendizado do reconhecimento precoce de cânceres da pele. Disponível em:<http://www.saudeparavoce.com.br/pintanapele>. Acesso em 28 abr. 2005.

FALCÃO, S.C. et al. (2001). Processo modificado de reprodução e amplificação de imagem para mensuração de área por planimetria. Aplicação em feridas planas produzidas em cães, tratadas por curativos oclusivos de pele de rã. Brazil. J. Vet. Res. and An. Sci., São Paulo, v.38, n.4, p.165-169.

FRIESS, W. (2001). Biomedical applications of collagen. Internat. J. Pharma., Amsterdam, v.221, n.1/2, p.1-22, June.

GIBSON, T. (1986). The 'second set'-phenomenon as first shown in allografts. An historical case which shows also the behaviour of cell free collagen. Brit. J. Plast. Surg., Edinburgh, v.39, n.1, p.96-102, Jan.

GIGLIOTI, A.F. (2005). Matrizes acelulares de colágeno: elastina a partir da desvitalização do pericárdio bovino: caracterização química, físico-química e estrutural. Tese (Doutorado) - Instituto de Química de São Carlos, Universidade de São Paulo, São Carlos, 2005.

UNIVERSIDADE DE SÃO PAULO (1996). GOISSIS, G.; PLEPIS, A.M.G.; ROCHA, J.L. Processo de extração de colágeno de tecidos animais com auxílio de solvente orgânico em meio alcalino. PI BR 9.405.043-0.

GREEN, H.; KEHINDE, O.; THOMAS, J. (1979). Growth of cultured human 
epidermal cells into multiple epithelia suitable for grafting. Proceed. Nation. Acad. Sci., Washington, v.76, n.11, p.5665-5668, Nov.

HAFEMANN, B. et al. (1999). Use of a collagen/elastin-membrane for the tissue engineering of dermis. Burns, Guildford, v.25, n.5, p.373-384, Aug.

HICKERSON, W. et al. (1994). Cultured epidermal autografts and allodermis combination for permanent burn wound coverage. Burns, Guildford, v.20, Suppl.1, p.S52-5; discussion S55-6.

HUC, A., (1985). Collagen biomaterials characteristics and applications. J. Amer. Leath. Chem. Assoc., Easton, v.80, n.2, p.195-212.

JUNQUEIRA, L.C.; CARNEIRO, J. (1990). Histologia básica. 7.ed. Rio de Janeiro: Guanabara Koogan. Cap.18, p.271.

KANGESU, T. et al. (1993). Kerato-dermal grafts: the importance of dermis for the in vivo growth of cultured keratinocytes. Brit. J. Plast. Surg., Edinburgh, v.46, n.5, p.401-409.

KATO, T. (1993) Collagen fibers for use in medical treatments. [S.I.: s.n.]. US 4.420339 .

KLEIMAN, I. et al. (1987). Aspectos atuais do processo de reparação tecidual. Acta Cirúrg. Bras., São Paulo, v.2, n.2, p.19-21.

KNAPP, T.R. (1983). Development of an injectable collagen for soft tissue restoration. In: RUBIN, R.L. (Ed.). Biomaterials in reconstructive surgery. London: C.V.Mosby. p.882-909.

KREIS, R.W. et al. (1989). The use of non-viable glycerol-preserved cadaver skin combined with widely expanded autografts in the treatment of extensive thirddegree burns. J. Trauma, Baltimore, v.29, n.1, p.51-54, Jan.

LEE, C.H.; SINGLA, A.; LEE, Y. (2001). Biomedical applications of collagen. Internation. J. Pharmac., Amsterdam, v.221, n.1/2, p.1-22, June.

LIGHT, N.; BAYLEI, A.J. (1980). Molecular structure and stabilization of the collagen fibre. In: VIIDIK, A.; VUUST, J. Biology of collagen. London: Academic Press. p.15-38.

LIPTAK, J.M. (1997). An overview of the topical management cutaneous wound healing. Australian Veterinary Journal, Sydney, v.75, n.6, p.408-413, June.

MACGRATH, M.H.; SIMON, R.H. (1983). Wound geometry and the kinetics of wound contraction. Plast. and Reconstruct. Surg., Baltimore, v.72, n.1, p.66-73, July. 
MARTINS, V.C.A. et al. (1998). The controlled release of a antibiotic by hydroxyapatite:anionic collagen composites. Artificial Organs, Cleveland, v.22, n.31, p.215-221, Mar.

MAYNE, R.; BURGESON, R.E. (1987). Structure and function of collagen types. London: Academic Press.

MENDES, I.S. (2003). Preparação e caracterização de matriz colagênica derivada de serosa. Monografia - Instituto de Química de São Carlos, Universidade de São Paulo, São Carlos, 2003.

NCSI - Consultoria em Sistemas Informáticos. Disponível em: $<$ http://www.tattooremove.com>. Acesso em: 28 abr. 2005.

NIMNI, M.E. (1988). Collagen. Boca Raton: CRC Press. v.1, p.3-23.

PROCKOP, D.J.; KIVIRIKKO, K.I. 1995). Collagens: molecular biology, diseases, and potentials for therapy. Ann. Review of Biochemistry, Palo Alto, v.64, p.403434, July.

PRUITT, B.A. et alee (1984). Characteristics and uses of biological dressings and skin substitutes. Archives of Surgery, Chicago, v.19, n.3, p.312, Mar.

PURNA, S.K.; BABU, M. (2000). Collagen based dressings - a review. Burns, v.26, p.54-62.

RADHIKA, M.; BABU, M.; SEHGAL, P.K. (1999). Celular proliferation on desamidated collagen matrices. Compar.. Biochem. Physiol., part C, Oxford, v.124, n.2, p.131-139, Oct.

RHEINWALD, J. G.; GREEN, H. (1975). Serial cultivation of strains of human epidermal keratinozytes: the formation of keratinizing colonies from single cells. Cell, Cambridge, v.6, n.3, p.331-344, Nov.

RUBIN, A.L. et al. (1973). Collagen as a vehicle for drug delivery: preliminary report. J. Clin. Pharmacol., New York, v.13, n.8, p.309-312, Aug.

RUE, L.W. et al. (1993). Wound closure and outcome in extensively burned patients treated with cultured autologous keratinocytes. J. Trauma, Baltimore, v.34, n.5, p.662-668, May.

SANTOS, V.L.C.G. (2000). Avanços tecnológicos no tratamento de feridas e algumas aplicações em domicílio. In: DUARTE, Y.A.O.; DIOGO, M.J.D. Atendimento domiciliar: um enfoque gerontológico. São Paulo: Atheneu. p.265306. 
SHER, S. et al. (1983). Acceptance of allogeneic fibroblasts in skin equivalent transplants. Transplantation, Baltimore, v.36, n.5, p.552-557, Nov.

SHERIDAN, R.L.; TOMPKINS, R.G. (1999). Skin substitutes in Burns. Burns, Guildfors, v.25, n.2, p.97-103, Mar.

SILVER, F.; DOILLON, C. (1989). Biocompatibility, interactions and implantable materials. New York: VCH. v.1.

SLATTER, D.H. et al. (1982). Ocular inserts for application of drugs to bovine eyes: in vivo and in vitro studies on the release of gentamicin from collagen inserts. Austral. Vet. J., Sydney, v.59, n.1, p.4, July.

SMITH, J.W. (1968). Molecular pattern in native collagen. Nature, London, v.219, n.15, p.157-163, July.

SPINOSA, H.S. et al. (1999). Farmacologia aplicada à medicina veterinária. 2.ed. Rio de Janeiro: Guanabara Koogan. p.532-533..

STEPHEN, T. (1990). Semipermeable film dressings in wound management and dressings. London: The Pharmaceutical Press. p.25-34.

TRAUB, W.; PIEZ, K.A. 1971). The chemistry and structure of collagen. In: ANFINSEN, C.B.; EDSALLA, J.T.; RICHARDS, F.M. (Eds). Advances in protein chemistry. New York: Academic Press. v.25, p.245.

VASCONCELOS, R. (2005). Histologia. Disponível em: <http://molbr.vilabol.uol.com.br/hist.htm>. Acesso em dia fev. 2005.

WASSERMANN, D. et al. (1988). Preliminary clinical studies of a biological skin equivalent in burned patients. Burns, Guildford, v.14, n.4, p.326-330, Aug.

WIEMAN, T.J. (1998). Introduction to care of chronic wounds. Amer. J. Surg., New York, v.176, n.2, supl.1, p.15-25, Aug.

WILLIAM, D.F. (1987). Definitions in biomaterials. New York: Elsevier.

YANG, C.C. et al. (1979). The intermingled transplantation of auto- and homografts in severe burns. Burns, Guildford, v.6, n.3, p.141-145, Mar.

YANNAS, I.V.; BURKE, J.F. (1979). The intermingled transplantation of auto- and homografts in severe burns. Burns, Guildford, v.6, n.3, p.141-145, Mar.

ZACHARIAS, D.P.M. et al. (1991). Efeito da nutrição protéica sobre a resposta cicatricial ao trauma: aspectos histológicos, histoquímicos e contração cicatricial. Acta Cirúrg. Brás., São Paulo, v.6, p.97-102. 